Boston University School of Law

Scholarly Commons at Boston University School of Law

Faculty Scholarship

2005

Theater in the Courtroom, the Chicago Conspiracy Trial

Pnina Lahav

Follow this and additional works at: https://scholarship.law.bu.edu/faculty_scholarship

Part of the Law Commons 


\section{BOSTON UNIVERSITY SCHOOL OF LAW}

Working Paper Series, Public Law \& Legal Theory

Working PAPER No. 02-16

\section{THEATER IN THE COURTROOM: THE CHICAgo CONSPIRACY TRIAL}

PNINA LAHAV

This paper can be downloaded without charge at:

The Boston University School of Law Working Paper Series Index: http://www.bu.edu/law/faculty/papers

The Social Science Research Network Electronic Paper Collection: $\underline{\text { SSRN_Location }}$ 


\title{
Theater in the Courtroom: The Chicago Conspiracy Trial
}

\author{
Pnina Lahav (C) \\ Professor of Law, Boston University \\ [Please do not quote, cite, or circulate without author's permission.]
}

\begin{abstract}
"We are not running a circus. This happens to be a court." Judge Julius J. Hoffman, In the matter of David T. Dellinger et al, 461 F.2d 389, 424 (1972) (Judge Hoffman's statement to Abbie Hoffman on October, 23, 1969).
\end{abstract}

"This was an example of guerrilla theater." Abbie Hoffman, In the matter of David T. Dellinger et al, 370 F.Supp. 1304. Trial transcript, p.2838.

"In its fusion with the American idiom our ever-changing language has rarely been richer, and yet it does not seem that the word is the same tool for dramatists that it once was. Is it that we are living in an age of images? Is it even that we must go through a period of image-saturation, for the need for language to re-emerge?" Peter Brook, The Empty Space (New York: Touchstone, 1968) 48.

\section{Before The Curtain Rises}

The Chicago Conspiracy Trial is generally remembered for the amusing antics of the defendants, the most colorful of whom was Abbie Hoffman. Those with personal memory of the Trial also remember the eccentric Judge Julius Jennings Hoffman, whom the defense fondly nicknamed Mr. Magoo. But it is more than that. It has a familiar yet intriguing plot. The government displays the visible leaders of the protest movements in the late 1960s on trial, charging them with an intent to undermine the democratic process. The trial contains allegations and counter-allegations of conspiracy, betrayal and behind the scenes politics. It has subplots involving a white upper middle-class judge and a Black Panther leader, and defendants who call themselves "the conspiracy", but "cannot agree on lunch." ${ }^{11}$ It captures the multi-ethnic rainbow of American society on both sides of the political divide: Irish-Americans, American Jews, African-Americans, Polish-Americans, and one white Anglo-Saxon Protestant. ${ }^{2}$ It has sex. ${ }^{3}$ It contains grotesque scenes, amazing spectacles, poignant and intense dialogues. It presents the 
grand epic of the 1960s in America, complete with the civil rights movement, the war in Vietnam, the counterculture, and the deep splits they caused.

Small wonder then, that the trial has inspired a play, a movie, scenes in Woody Allen's now classic film Bananas, comments by Archie Bunker on the All in the Family television show, and a monologue in E. L. Doctorow's novel The Book of Daniel. ${ }^{4}$ Numerous books and articles described the events, and many of the participants published memoirs recalling what probably was the defining moment in their lives. ${ }^{5}$

At the same time, the trial itself was a child of the 1960s. It must have been influenced by innovations in the theory of the theater that reverberated throughout this extraordinary decade. The Diggers in northern California, ${ }^{6}$ the concept of guerrilla theater, ${ }^{7}$ and Julian Beck's and Judith Malina's The Living Theater, which was hosted by the Yale Repertory Theater in $1968^{8}$-all have their fingerprints on scenes from the trial. These perspectives -- the trial as inspired by, and the trial as inspiration to, theater -- make the Chicago Conspiracy Trial a wonderful repository of materials to study the cross-fertilization between law and theater. My aim is different. It is to try to understand the way in which the theatrical elements of the trial itself could illuminate the meaning of law and the meaning of trials. ${ }^{9}$

I shall start with a short synopsis of the trial as a play. I shall then proceed to discuss the interaction between law and theater and the theory of the rough theater. I believe that the techniques of the rough theater made the trial so fascinating to some, so repelling to others, and such a unique experience to all who watched and followed it. I shall then analyze scenes from the trial. First I shall apply the theoretical framework of theater by contrasting two scenes rooted in the trial. One falls into the category of rough theater, and the other into the category of deadly theater. I shall then analyze the major scene of the first act -- the binding and gagging of Bobby Seale, and follow by an analysis from a scene located close to the end of the trial when two defendants appeared in court wearing judicial robes. Finally, I shall address the question of how subsequent courts related and reacted to these extraordinary events. In conclusion, I shall offer some comments on the value of theater as a medium capable of shedding light on the meaning of law and trials. 


\section{Prologue}

Act I: A quick sequence of scenes. A judge, Julius J. Hoffman, is reading an indictment to hundreds of prospective jurors. A defense attorney, William M. Kunstler, rises in indignation:

Mr. Kunstler: (angry) Your Honor... we object to the reading in a manner in which Orson Welles would read the Declaration of Independence... We make an objection to that dramatic reading.

The Court: (beaming) I am very grateful that you compare me to Mr. Orson Welles, one of the truly great actors in the American Theatre. I am very grateful and I overrule your objection. (laughter in the courtroom) ${ }^{10}$

Eight defendants, indicted for conspiracy to cross state lines with an intent to incite a riot, are presented to the jury. ${ }^{11}$ One, Tom Hayden, shakes his clenched fist at the jury in the "customary salute" of "the movement." Another, Abbie Hoffman, blows a kiss to the jury - his way of expressing his Yippie philosophy of "make love not war." A third defendant, Bobby Seale, insists that none of the defense lawyers present in the courtroom represents him. ${ }^{12}$

Three weeks later. In the courtroom, before the court session opens, the defendants are busy spreading two flags on their table. One American, the other Vietcong. They plan to observe Vietnam Moratorium Day in the courtroom by reading the names of the war dead, American and Vietnamese. A marshal rushes in, snatches the Vietcong flag, then quickly leaves. Within seconds he rushes back, this time removing the American flag. On the empty podium, a lone American flag remains untouched. ${ }^{13}$

The government presents its case. City administrators, police officers, FBI undercover agents appear as witnesses. They present the defendants as a sinister group that conspired to hold riots in Chicago during the Democratic National Convention. Bobby Seale, chairman of the Black Panther Party for Self-Defense, and the only black defendant, sitting somewhat aloof from the other defendants, occasionally interrupts. He wants to cross-examine the witnesses. $\mathrm{He}$ insists he has a constitutional right to represent himself because his lawyer of choice is not present. A confrontation escalates. The judge warns the defendant that if he persists in violating the court's rules he might be bound and gagged. Judge and defendant grow angrier.

Seale is chained to a chair, his mouth covered with a bandage secured by adhesive tapes. He struggles. He shouts through his gag. Spectators, members of the jury, members of the press, the attorneys, all watch with increasing terror. The judge declares a mistrial. The Chicago Eight become the Chicago Seven. 
End of Act I.

Act II: The defense presents its case. Well-known figures from the entertainment and art world, as well as Left intellectuals, appear as witnesses. They explain the horrors of the (in their view unconstitutional, because undeclared) war in Vietnam, the efforts to get permits to demonstrate and march (exercise their first amendment rights), the youth culture. Among them is a singer known as Country Joe. The following unfolds:

The Court: You still call him Country Joe even though his name is McDonald? Mr. Kunstler: I know, your Honor, but he is known throughout the world as Country Joe. The Court: That is what you say. I have never heard of him.

Mr. Kunstler: Now, would you state for the jury what was said by those people who participated as you can remember.

The Witness: I said to Jerry Rubin, "the Yippie thing in Chicago, what do you want us to do?" Jerry Rubin said to me, "We feel that the Democratic Convention being held in Chicago is a very important political event" and that it was the responsibility of those people, young people... to do something ... And since I had written the Vietnam Rag, which has become the most well known song against the war in Vietnam, and that my group was very influential with young people in America, it was very important that we try to say something in Chicago which would be positive, natural, human, and loving... At that point Abbie Hoffman wanted to know what the song was, then I sang the song. It goes [sings], “And it's one, two, three what are we fighting for? Don't ask me, I don't give a damn. Next stop in Vietnam. And it's - “

The Court: No, no, no. Mr. Witness. No singing.

The Witness: "five, six, seven - “"

The Court: Mr. Marshal -

Deputy Marshal John J. Gracious: The judge would like to speak to you.

The Court: No singing is permitted in the courtroom.

The Defense is about to end the presentation of its case. An excited attorney makes a motion; yes, on the previous day he did assure the judge that he was done with his live witnesses. But circumstances have changed. The Reverend Ralph Abernathy has just returned from abroad and is ready to testify. His testimony is crucial for the defense. The attorney makes a motion to present one more witness, assuring the judge he will be the last. The following unfolds:

The Court: In light of the representations made by you unequivocally, sir, with no reference to Dr. Abernathy, I will deny your motion...

Mr. Kunstler: Your Honor, I think that what you have just stated is about the most outrageous statement I have ever heard from a bench...

Voices: Right On. 
Mr. Kunstler: -- and these men are going to jail by virtue of a legal lynching Voices: Right on. Right on.

The Court: Out with those applauders. ${ }^{14}$

End of Act II.

Act III: Ten days before the end of trial. The government presents its rebuttal. During testimony of James D. Riordan, Deputy Chief of Police in the Chicago Police Department, the following unfolds:

David Dellinger: When it's all over the judge will go to Florida, but if he has his way, we'll go to jail. That is what we are fighting for, not just for us, but for all the rest of the people in the country who are being oppressed.

Voices: Right on.

The Court: Take that man into custody, Mr. Marshal. Take that man into custody ... (Jury excused)

The Court: ...I propose to try to end the use of such language if possible, and such conduct, by terminating the bail of this defendant. I do not, if I can help it, intend to permit such tactics to make a mockery out of this trial. ...

Mr. Kunstler: Your Honor, is there not going to be any argument on this?

The Court: No argument.

[The defendants are upset and a commotion takes place.]

Abbie Hoffman: You are a disgrace to the Jews. You would have served Hitler better.

Dig it.

...

The Court: Clear the court.

A Female Voice: You little prick.

Mr. Rubin: You are a fascist.

The Marshal: Get out of the courtroom. Let's go.

Mr. Hoffman: Oh, yes, I forgot, it is a public trial. ${ }^{15}$

Two days later, eight days before the end of the trial, seconds after the court enters into session, the door opens. Abbie Hoffman and Jerry Rubin appear before the stunned participants. They are wearing black judicial robes. Affixed to their robes is a yellow Jewish star. Then it is Jerry Rubin's turn to be stunned. Abbie Hoffman takes off his robe and reveals the shirt of a Chicago police officer (Abbie did not share his plans for this finale with his alleged coconspirator).

\section{End of Trial.}


The jury acquits all defendants of the charge of conspiracy. Five are convicted of the individual crime of crossing state lines with an intent to incite a riot. The judge also summarily convicts all defendants and their two attorneys of contempt of court. ${ }^{16}$ The harshest sentence falls on defense attorney William M. Kunstler: four years in prison. Bail is denied to the convicted defendants and they are taken away to jail. Outside of the courtroom, Anita Hoffman and Nancy Rubin, co-founders of the Yippie movement and wives of Abbie and Jerry, burn the judicial robes. Holding their fists high in the air they cry, "We will avenge the ten." "We will dance on your grave, Julie, Right on."17

The Curtain Falls.

Or does it? More events follow. The audience and participants somewhat change. The theater within a theater undergoes a transformation. The defendants are now represented by other lawyers. The government, too, replaces its lawyers. Different judges consider the case. The times are also changing. Some of those who were previously in the audience now become participants, and the audience at large is now watching from the vantage points of 1972 and 1973 respectively. The defendants' appeal the decision to deny bail and the Court of Appeals for the Seventh Circuit sets them free. Two years later, the Court of Appeals unanimously overturns Judge Hoffman's convictions and orders a new trial, both for the substantive convictions and for the convictions of contempt of court. ${ }^{18}$

Meanwhile, The scandals of Watergate shake the land. It becomes harder for the government to raise the banner of law and order when its top public officials are themselves implicated in violating the law and obstructing justice. ${ }^{19}$ The government decides to drop the original indictments. It does insist on trying the contempt of court charges. None of the federal district judges in Chicago is willing to preside over the new trial. ${ }^{20}$ Warren Burger, Chief Justice of the United States Supreme Court, designates Judge Edward T. Gignoux of Maine to be the judge. A rather uneventful and orderly trial follows. Four of the seven defendants are acquitted and three are found guilty of single items. ${ }^{21}$ Judge Gignoux also holds that because of the extenuating circumstances, no sentence should be attached to the convictions. The Court of Appeals for the Seventh Circuit affirms. 
Before the curtain falls, let us take note of Judge Gignoux's awareness that he was presiding over the final act of a morality tale. At the end of his opinion, Gignoux reaffirmed the principle that legality depended on rules and procedures: "Trials which proceed in accordance with the law, the rules of evidence and the standards of demeanor not only reaffirm the integrity and viability of the judicial process, but also serve to insure the ability of each one of us to protect the rights and liberties we enjoy as citizens." But that was too dry a lesson, and Gignoux evidently searched for a more vibrant and powerful finale, one which, he conceded, could not typically be found "in a judicial opinion or a legal treatise." He found it in Robert Bolt's play, A Man For All Seasons. In the dialogue he quoted, Sir Thomas More and Roper, his son-in-law, discuss the viability of the only way to save Sir Thomas' life: bending the law. Roper is willing to bend the law, Sir Thomas is not. He insists that law applies to all equally. If not, he warns his son-in-law, the devil will cut all the laws of the realm and leave people naked and helpless, vulnerable to his evil schemes. "For my own safety's sake", he concludes, "I would not accept any bending of the law." 22

\section{Trial and Theater}

A public trial is the centerpiece of the concept of justice, the core of the idea of due process. As such, its aims differ from those of the theater. It is meant to enforce the rule of law, to guarantee that justice is not only done but also seen. It is meant to assure that only the guilty are convicted and the innocent set free. ${ }^{23}$ Its implications are very serious. When a character in a play is denied bail unjustly, the audience may become upset, may go through catharsis, and may learn about justice. But the spectators know that it is just make believe, and that after the curtain falls the actor (who was thrown into jail or released by the court of appeals) takes off her makeup and goes home. ${ }^{24}$ In a real trial, denial of bail means incarceration, at least for a while. ${ }^{25} \mathrm{~A}$ terrible fall awaits the person whose conviction is followed by a prison sentence. In his seminal essay titled "Violence and the Word" Robert Cover admonished scholars to pay particular attention to the differences between literary and legal interpretations. Legal interpretation, particularly when applied by judges during trial, is a violence inflicting activity: "[1]egal interpretation is either played out on the field of pain and death or it is something less (or more) than law." 26 The experience of a trial may be traumatic even if the defendant is set free. 
Conviction may subject the defendant to far greater and prolonged violence. Thus, one should approach the task of comparing trial and theater cautiously.

And yet, even the maxim that justice should not only be done but also be seen contains the recognition that there is an affinity between trial and theater. "Seeing" summons the visual senses, implying that abstract comprehension is not enough. Indeed, the garden-variety trial has much in common with a theatrical production. The architecture of the courtroom resembles a playhouse. ${ }^{27}$ Many trial attributes have theatrical qualities: the stylized and ritualistic dialogue ("May it please the court"; "If your honor please"); the fact that the attorneys serve as intermediaries between the judge and the (mostly silent) defendants; the public rising when the robed judge enters and leaves; the movement created by the jury obediently entering and leaving the courtroom at the judge's command. In the ordinary trial these may be ill-executed or mechanical and therefore so boring that one barely considers them theater. At least not good theater. Still, they do bear a close resemblance to what goes on the stage.

Certain trials are anything but conventional. There is something about them -- sex, sensation, famous personages, politics -- which ignites the public attention, creates a fascination with the law, and crowns them (temporarily) with the title "trial of the century." ${ }^{28}$ Theater is an indispensable component of these trials.

Such trials have several features in common. First, they generally represent a problem of justice that tears the society apart. They bring to attention a legal problem that breaks the social consensus and make one camp of the public face the other camp resentfully and suspiciously. Such was the case in a few of the trials that entered the canon: the Scopes trial, the Rosenbergs Trial, the O.J. Simpson trial. This was certainly true of the Chicago Conspiracy Trial where one camp (represented by the government) saw the trial as representing the forces of law and order fighting against chaos and destruction. The camp represented by the defense perceived itself as carrying the banner of social justice and cultural openness against the forces of tyranny and authoritarianism. One could characterize the social context in which this trial occurred as "moral panic" -- a time when conventional society perceived its worldview to be threatened by sinister forces. $^{29}$

Secondly, these trials contain archetypal motifs that galvanize the collective imagination. In the O.J. Simpson trial it was race and violence in the family. ${ }^{30}$ In the Rosenbergs' trial it was betraying the nation's (community, tribe) vital secrets to the enemy. In the Chicago Conspiracy 
Trial it was the mythical theme of the conspiracy to incite the mob to riot. This perception that one was reliving the myth of the struggle of the children of light -- represented by the cherished and the familiar -- against the children of darkness, propelled the defense to appeal to the jury and court to remember the trials of Jesus Christ and John Peter Zenger. ${ }^{31}$

A special archetypal motif was forcefully enacted in the episode of the binding and gagging of Bobby Seale. The scene echoes the myth about the Greek god Prometheus who was sentenced by Zeus to be bound to a rock because he violated the rule that the benefits of fire (knowledge) should not be shared by humankind. I shall explore this motif in my analysis of the Seale incident below.

The archetypal quality of the Chicago Conspiracy Trial may be viewed from yet another angle. The archetypal trial revolving around the theme of freedom vs. tyranny or the suppression of dissent always begins with the insistence of the legitimate government that it is being undermined by the powers or ideas represented by the defense, and therefore that it is acting in self-defense. The defense typically protests that the government is out to crush freedom of conscience or freedom of speech. But soon a twist is introduced. The focus shifts from the government as the arch-hero or arch-villain to the judge presiding over the case. The performance of the judiciary is brought into question and begets close public scrutiny. Do the alleged "perpetrators of chaos," the defendants in the trial, abuse the judge, or is the judge abusing authority and corrupting the notion of justice (and therefore visiting chaos upon the community) by denying the defendants minimal fairness?

An undercurrent of a charge of collaboration between the executive branch and the judiciary accompany this focal switch. Other examples of such a shift are the impeachment trial of Justice Samuel Chase and the controversial performance of Judge Medina during the trial of the communist party leadership in the late 1940s in New York. ${ }^{32}$

Finally, to qualify as candidates for "the trial of the century" the particular trial must burst the shell of analytic language and cerebral discourse. The legal issues at trial must be presented in a way that inflames the collective imagination, they must engage the eye and the ear, not only the mind. It is here that the techniques of theater come into play and set such a trial apart from the garden variety. Sound, movement, and spectacle feed all the senses and bring the trial closer to a theatrical performance. 
Do I recommend that we import theater into trials? Certainly not. Some of the events in the Chicago Conspiracy Trial as described in the prologue sufficiently demonstrate the risks posed to the rule of law, justice, or the pursuit of truth when a courtroom is turned into theater. ${ }^{33}$

My argument is different. Even though a trial should be distinguished from theater, theater does illuminate certain qualities of trials. In certain cases the presence of the theatrical elements is so strong that it is ignored at the spectator's (scholar?) own peril. I wish to explore the question of what can be learnt about the law from the theatrical trial. Because the Chicago Conspiracy Trial occurred at a time of great social divisiveness, because it represented archetypal themes and because it was such amazing theater, it holds valuable insights about law and justice. These insights are generally invisible -- either hidden from the naked eye, or buried in learned legal treatises shared by too few to matter in the larger world. Furthermore, in examining how subsequent courts evaluate the theatrical scenes, in exploring what they see and to what they turn a blind eye, one can draw lessons about the deeper layers of law and justice in the minds of the judiciary.

\section{Deadly Theater, Rough Theater}

In 1968, the year of the Chicago Democratic Convention, theater director Peter Brook, at the zenith of his distinguished career, published a book titled The Empty Space. ${ }^{34}$ It articulated his philosophy of the theater. He offered three models: the deadly, the holy, and the rough theater. Brook's entire career, from a leadership role at the Royal Shakespeare Company to his involvement in film and opera, was devoted to liberating the theater from its "deadly" condition and restoring its vitality. ${ }^{35}$ His book aimed to explain the contribution of the rough theater to knowledge and understanding.

By deadly, Brook meant boring rather than dead theater. The deadly theater was typified by a condition reflecting "the unattractive fact that most of what is called theater anywhere in the world is a travesty of a word once full of sense." The ideal of theater full of sense, he suggested, was "the Holy Theater:" "A theater striving to make the invisible - visible." ${ }^{36}$ But that, he believed, was not attainable in our time and in any event should be distinguished from the deadly theater, which masquerades as noble by trying to be "nice" or "decent". ${ }^{37}$

At the core of the deadly theater Brook observed a worthy dream - a desire to bring out and imprint onto the minds of the audience some transcendent experience, some truth about life 
that everyday reality cannot capture. In his view, the more intellectual theater [which meant to fulfill the ideal through text], has become wooden and sterile. Good reading, perhaps, and yet missing something. The reason for this was that following the glorious days of the Elizabethan theater words gradually lost their magical power to dive into the depths of the human experience and bring to the surface the incarnation of that "invisible." 38 The remedy, Brook advised, was to use the techniques of the rough theater: images, spectacles, sound, action. These would succeed in catching that deep meaning where words failed:

I have sometimes been accused of wanting to destroy the spoken word, and indeed in this absurdity there's a grain of sense. In its fusion with the American idiom our everchanging language has rarely been richer, and yet it does not seem that the word is the same tool for dramatists that it once was. Is it that we are living in an age of images? Is it even that we must go through a period of image-saturation, for the need for language to re-emerge? This is very possible, for today writers seem unable to make ideas and images collide through words with Elizabethan force. ${ }^{39}$

Brook relied on the insights of the poet and theater critic Antonin Artaud in order to develop remedies for the deadly theater and bring it closer to the ideals of the Holy Theater. Artaud, who developed the theory of the theater of the avant-garde during the 1930's and 1940's, emphasized the significance of the spectacle, of symbolism, and of the mis-en-scène. For Artaud, the spectacle was a means to make the audience experience ideas not only intellectually but with all of their senses: the eye, the ear, the nervous system, maybe even the nose. Thereby the spectators would briefly get in touch with the dark depths of the human unconscious.

The theater must also be considered as the Double, not of this direct, everyday reality of which it is gradually being reduced to a mere inert replica -- as empty as it is sugarcoated -- but of another archetypal and dangerous reality, a reality of which the Principles, like dolphins, once they have shown their heads, hurry to dive back into the obscurity of the deep. ${ }^{40}$

Bertold Brecht, developing his own insights into the meaning of theater at about the same time as Artaud, emphasized the notion of alienation. If Artaud looked for the kernel of truth wrapped in many layers of reason and rationality, Brecht sought "to shock us into bringing the best of our reason into play."41 Alienation as practiced by Brecht and his followers, Brook observed, "pricks the balloons of rhetorical play." "Alienation can work through antithesis; parody, imitation, criticism, the whole range of rhetoric is open to it. It is the purely theatrical method of dialectical exchange." ${ }^{42}$ Both Artaud, prophet of the theater of the avant-garde, and 
Brecht, one of the leading theorists of the theater in the twentieth century, sought to rejuvenate the theater through methods employed by the Rough Theater or the Theater of Cruelty. ${ }^{43}$ The roughness of the spectacle, the parody of conventional forms, was seen as a means to impart to audiences some truth that is generally hidden underneath the visible surface of everyday life.

In the 1960s these theories were expanded and practiced by such influential thinkers as Jan Kott and Robert Brustein. ${ }^{44}$ Kott was a prominent drama critic and an authority on Shakespeare. His work had directly influenced Brook's interpretation of Shakespeare's King Lear. $^{45}$ He thought that:

All Shakespeare's plays are great spectacles abounding in clatter of arms, marching armies, duels, feasts and drunken revels, wrestling contest, clowning, winds and storms, physical love, cruelty and suffering. Elizabethan theater was - like the Chinese opera - a theater for the eyes. Everything in it was really happening. ${ }^{46}$

When Robert Brustein arrived at Yale University to dean its school of drama and to establish the Yale Repertory Theater, he was already known for his view that the contemporary theater was in need of dehydration. ${ }^{47}$ One of his first productions was Robert Lowell's adaptation of Aeschylus' Prometheus Bound, directed by Jonathan Miller. ${ }^{48}$ The play deserves mentioning here because the Promethean myth is embedded in the scene of binding and gagging of Bobby Seale in the Chicago Conspiracy Trial as I shall show below. The coincidence of the Yale production and the trial in Chicago prove that the archetypal Promethean myth was stirred in the collective mind during the fateful years of 1968 and 1969.

Robert Lowell's adaptation of Prometheus Bound contained references to the Vietnam War and the Johnson Administration, and followed his much-publicized rejection of an invitation to a White House party for the arts. ${ }^{49}$ It became a significant example of the application of the rough theater to the classics. Thus, Kott, Brustein, and Lowell were legitimizing the ideas of the rough theater and applying Brook's techniques in the United States.

A brief review of theater at Yale in 1968 provides both an insight into the methods of the rough theater and an understanding of the cultural and social background of the Chicago Conspiracy Trial. In his memoirs Robert Brustein recalls the production of Joseph Heller's "We Bombed in New Haven." The play, Brustein recalled:

concerned a group of air force personnel fighting in an unnamed war for an unnamed cause, gradually being blasted away by an unnamed enemy. The final scene - which I found very moving - showed the weak-willed Captain Starkey, trying to find a 
replacement for one of the dead soldiers. The first candidate turns out to be his own son. Since the replacement is destined for certain death, Starkey helps his son to escape through a window and calls for the next candidate. This too turns out to be his son. Each time the boy escapes, he reappears at the door until, pale and shaken and solitary, Starkey is forced to send him off to his death. ${ }^{50}$

To show its support for the play's message, The Yale Draft Refusal Committee had purchased a block of seats for the opening night. But the Anti War Movement was not monolithic. Some radical students of the Yale School of Drama felt that We Bombed in New Haven, particularly its final scene, was counterrevolutionary and a capitulation to the war. With the help of SDS members, they were planning to gather in the orchestra during the final scene and shout, "Hell no, we won't go."

This anecdote is interesting for the following reasons. The small act of sabotage was certainly based on a different interpretation of the meaning of the play. The presence of the two groups in the audience, one in support of Heller's view and the other in opposition, even the popular slogan "Hell no, we won't go" shouted from the orchestra, could be seen as theater within the theater. They could be perceived as a move that Artaud or Brook would welcome, signifying the most intense involvement of the audience with the subject matter displayed on the stage. At the same time, it was disruption pure and simple. As Brustein tells it, he and Jules Feiffer, "whose anti war credentials were impeccable", met with the recalcitrant students and persuaded them to abandon their plan. ${ }^{51}$

The thread connecting the New Haven play and the Chicago Conspiracy Trial is artist Jules Feiffer. Feiffer was a noted presence in left wing circles at the time, and covered the Chicago Conspiracy Trial. ${ }^{52}$ The Trial itself, the reader may recall, was frequently interrupted with cries of "right on" by excited spectators who came to support the defendants, the same guys who would shout "Hell no, we won't go" in public gatherings. ${ }^{53}$ While Feiffer was willing to dissuade the spectators from disrupting the play in New Haven, it is not clear that he did so in Chicago. Maybe he felt that what was appropriate for the trial was inappropriate for the theater. Or he may have thought that dialogue was possible between members of the same camp (moderate and extreme left), but not between the camps themselves: the government on the one hand, and the protest movement on the other.

As we shall see, the Chicago Conspiracy Trial contained many attributes of the rough theater. This is, in fact, the reason why Judge Hoffman firmly stated that "We are not running a 
circus, this happens to be a court" evidently trying to nip this transformation in the bud. Indeed, as Brook explains, the rough theater was heavily influenced by the practices of the circus. ${ }^{54} \mathrm{But}$ the conventional trial, as I discussed above, also contains attributes of the theater. Certainly Judge Hoffman did not object to the ritualistic and theatrical aspects of the conventional trial: the courtroom's architecture; the stylized, high and somewhat obscure language; the rising every time he comes and goes; the judicial robe. Feeling theatrical, Judge Hoffman read the indictment with the dramatic pathos of "Orson Wells reading the Declaration of Independence." ${ }^{55}$ Thus it appears that Judge Hoffman and his followers did not object to theater in the courtroom per se, but rather to the invasion of the rough theater into their territory.

Two models of the theater were thus crossing swords at the Chicago Conspiracy Trial, the deadly and the rough theater. One is tempted, at this point, to argue that the court adhered to the techniques of the deadly theater while the defendants attempted to reshape the trial through the techniques of the rough theater. However, it was Judge Hoffman, not the defense, who initiated one of the most dramatic and frightening scenes of the trial - the binding and gagging of Bobby Seale. As I shall show, this was a spectacle worthy of Artaud and Brook. Thus shortly after Judge Hoffman warned, "We are not running a circus", he found himself experimenting with techniques based on that cousin of the circus - the rough theater.

\section{A Preliminary Contrast between Deadly and Rough Theater: A Man}

\section{For All Seasons v. the Abernathy Incident}

Three years after the end of the Chicago Conspiracy Trial, Judge Edward T. Gignoux presided over a trial of the contempt charges against five of the defendants and their two attorneys. The Circuit Court had already designed a very strict doctrine of contempt to be applied (while overruling Judge Hoffman's summary convictions) and Judge Gignoux acquitted all of the defendants of half of the charges and convicted four of them of the other half. ${ }^{56}$ As often happens with morally charged cases, Judge Gignoux looked for a text that would end his opinion with an inspiring bang. He chose a dialogue from Robert Bolt's play, A Man for All Seasons. ${ }^{57}$ The hero of this play is Sir Thomas More, and the play presents him as a man of unbent principles and sterling integrity. In the following dialogue that occurs just before Sir Thomas' confrontation with the King escalates, Sir Thomas and his son-in-law, both lawyers have an argument: 
Roper: So now you'd give the devil the benefit of the law!

More: Yes, what would you do? Cut a great road through the law to get after the Devil? Roper: I'd cut down every law in England to do that!

More: Oh? And when the last law was down, and the Devil turned round on you - where would you hide, Roper, the laws all being flat? This country's planted thick with laws from coast to coast -- man's laws, not God's -- and if you cut them down -- and you're just the man to do it -- d'you really think you could stand upright in the winds that would blow them? Yes, I'd give the Devil benefit of law, for my own safety's sake." 58

This dialogue presents the lofty idealism of the rule of law. The principle of the rule of law guarantees legal protection even to the devil. Sir Thomas emphasizes that the devil is at liberty to think and act in most despicable ways, as long as he does not violate the law. Law, Sir Thomas implies, should be distinguished from morality, and the "is" should not be confused with the "ought." This is not the place to analyze Bolt's play or to inquire into the question of whether it falls into what Brook called deadly theater. My analysis is limited to the excerpt from the play placed strategically at the end of the Contempt Trial of the Chicago defendants.

Judge Gignoux emphasized that his example did not come from a legal text. Evidently, he felt that ("deadly") legal language could not capture the timeless and vibrant morality that he sought to impart. Indeed, within the genre of legal literature his choice is a rather moving exchange between two lawyers, pondering the tension between principle and pragmatism. It is easy to understand why it would appeal to the legal imagination. And yet the dialogue contains many of the problems of the deadly theater flagged by Peter Brook. It is a cerebral text, words presenting a legal hypothesis. The visual senses are not involved. ${ }^{59}$ The devil is abstract. A naked hypothesis is advanced, bereft of concrete details, and the dialogue centers around the parade of horribles otherwise known as the slippery slope. ${ }^{60}$

The Bolt-Gignoux dialogue makes an excellent point of departure for a first-year law school class. One can imagine applying it, say, to Bush v. Gore, triggering a lively debate about whether Justice Scalia was playing the part of Sir Thomas or of Roper; whether he was saving the Republican candidate as Alan Dershowitz thinks, or The Republic as Judge Richard Posner maintains. ${ }^{61}$ A spirited debate may then follow about the "is" versus the "ought" or about the concept of the slippery slope.

Yet as theater, as something that should be seen and felt, does the dialogue ignite "an apprehension of the subtlest motions", as Artaud would have it do? ${ }^{62}$ Does it, in Peter Brook's language, "prick the balloons of rhetorical playing"? Even if one accepts that good theater may 
be based on a sober exchange between two characters, appealing mainly to the intellect, it is hard to perceive the depth provided by Bolt's dialogue. Few would disagree that the rule of law, as an abstract ideal, is glorious. ${ }^{63}$ The dialogue's considerable appeal (particularly for members of the legal profession) may lie precisely in the fact that it does not engage in making the invisible visible, but rather in a cover-up. The audience goes home soothed, comforted, and content, feeling that Sir Thomas died for a worthy cause, knowing that at the end he was vindicated as a saint. $^{64}$

This genre would fall into what Northrop Frye called the "primitive idea of drama," where the play "presents to the audience a myth already familiar to and significant for that audience, and [it is] designed to remind the audience of their communal possession of this myth." ${ }^{65}$ In the Bolt-Gignoux dialogue, the myth is the rule of law. Even the devil is welcome in Law's Republic, as long as he abides by its laws. And those entrusted with the faithful execution of the laws will not touch the devil, unless he violates a law. A morality tale has been told and reaffirmed. One may now continue to go about one's business, making one's own little compromises with law or with the devil and not give them a second thought.

To problematize the idea of the rule of law and present its complexity, a Brechtian dialogue, a more searching understanding of the meaning and the limits of law is called for. ${ }^{66}$ Such a dialogue will expose the fragility and vulnerability lying beneath the clichés and banalities.

Compare Bolt's scene with the exchange in what I called Act II of the Trial. ${ }^{67}$ It is Monday. On the previous Friday, defense attorney Kunstler told Judge Hoffman that the defense ended its presentation of live witnesses. Now Kunstler states that circumstances have forced him to take his words back. He asks permission to present one last witness, Reverend Ralph Abernathy, ${ }^{68}$ whose testimony, he claims, is crucial for the defense. Kunstler also offers an explanation of why he did not include the witness earlier. ${ }^{69}$ Here is a full version of the exchange in court:

The Court: ...I think in the light of the representations made by you unequivocally, sir, with no reference to Dr. Abernathy, I will deny your motion that we hold-Mr. Kunstler: Your Honor, I think what you have just said is about the most outrageous statement I have ever heard from a bench, and I am going to say my piece right now, and you can hold me in contempt right now if you wish to. 
You violated every principle of fair play when you excluded Ramsey Clark from that witness. The New York Times, among others, has called it the ultimate outrage in American justice. Voices: Right on.

Mr. Kunstler: I am outraged to be in this court before you. Now because I made a statement on Friday that I had only a cameraman, and I discovered on Saturday that Ralph Abernathy, who is the chairman of the Mobilization, is in town, and he can be here, I am trembling because I am so outraged. I haven't been able to get this out before, and I am saying it now, and then you can put me in jail if you want to. You can do anything you want with me, because I feel disgraced to be here.

To say to us on a technicality of my representation that we can't put Ralph Abernathy on the stand. He is the cochairman of the MOBE. He has relevant testimony. I know that doesn't mean much in this court when the Attorney General of the United States walked out of here with his lips so tight he could hardly breathe, and if you could see the expression on his face, you would know, and his wife informed me he never felt such anger at the United States Government as at not being able to testify on that stand.

I have sat here for four and a half months and watched the objections denied and sustained by your Honor, and I know that this is not a fair trial. I know it in my heart. If I have to lose my license to practice law and if I have to go to jail, I can't think of a better cause to go to jail for and to lose my license for --

A Voice: Right on.

Mr. Kunstler: -- than to tell your Honor that you are doing a disservice to the law in saying that we can't have Ralph Abernathy on the stand. You are saying truth will not out because of the technicality of a lawyer's representation. If that is what their liberty depends upon, your Honor, saying I represented to you that I had a cameraman that was our only witness, then I think there is nothing really more for me to say.

The Court: There is not much more you could say, Mr. Kunstler.

Mr. Kunstler: I am going to turn back to my seat with the realization that everything I have learned throughout my life has come to naught, that there is no meaning this court, and there is no law in this court --

Voices: Right on.

Mr. Kunstler: -- and these men are going to jail by virtue of a legal lynching -Voices: Right on.

Mr. Kunstler: And that your Honor is wholly responsible for that, and if this is what your career is going to end on, if this is what your pride is going to be built on, I can only say to your Honor, "Good luck to you."

Voices: Right on. Right on.

The Court: Out with those applauders.

Mr. Davis: I applauded too, your Honor. Throw me out.

The Court: Unfortunately, you have to remain, Mr. Davis, but we note that you applauded. You say you applauded. ...

This scene is mostly made of words, with a dash of spectacle. The dialogue is between the lawyer and the judge -- as in A Man for All Seasons, two members of the legal profession. It 
is about justice and the search for truth in the adversarial process that is the cornerstone of the common law of criminal procedure. ${ }^{70}$ In other words, it is about a concrete, as distinguished from abstract, problem grounded in the principle of the rule of law. The judge has discretion to accept -- but decides to deny -- the motion to present one last witness, and the lawyer is outraged. A judge's discretion must not be arbitrary. He must be guided by the principle that a defendant is innocent until proven guilty and is entitled to due process. But a judge must also make sure of some standards of efficiency in moving the trial to conclusion. The lawyer ought to navigate between two contradictory, yet cardinal, principles -- he is at once a zealous advocate -hence must do all in his power to prove his client's innocence -- and an officer of the court. In his latter capacity, he ought to refrain from undermining the legitimacy of the court.

Unlike A Man For All Seasons, where the dialogue with the devil is imagined (in Bolt's play the alleged devil (Richard Rich), has already left the scene), this scene is complicated by presenting theater-within-theater. All the trial participants are present and the dialogue takes place before them as well as before and with the help of the trial spectators. The dialogue heats up, added by the electrifying presence of the spectators. The lawyer addresses the judge as "your honor", but his words convey contempt for a judge whom he sees as an abuser of his very obligation under the law. ("I know that this is not a fair trial.") The lawyer asserts that he is trembling before the horrible sight of the denial of due process. He is encouraged by the spectators ("right on"), and his tirade grows bolder: “...You are saying truth will not out because of the technicality of a lawyer's representation. If that is what their liberty depends upon, your Honor... then I think there is nothing really more for me to say." To this rather long speech, the judge responds laconically: "There is not much more you could say, Mr. Kunstler."

Herein lay the Brechtian alienation offered by Brook as a means of revitalizing deadly text. The spectator realizes that the notion of the rule of law is complex. Does "technicality" qualify as "law"? Was the judge correct in denying the motion? Was he just? Does the rule of law include a component of justice, or is it independent of it? Kunstler goes on to declare that he has "nothing more to say." That is, presumably, because he feels that reason has been banished from the courtroom and that therefore his legal skills in attempting to persuade the judge by convincing arguments are useless. The rigidity with which the judge had rejected his motion ("I like to rely on the representations of lawyers") strikes him as absurdly formalistic and technical, and at the same time symptomatic of the judge's hostility to the defense ("I have sat here for four 
and a half months and watched the objections denied and sustained by your Honor"). The spirit of due process and of the search for truth would require, he implies, a more flexible approach to his Friday representation.

Kunstler is frustrated about the roadblocks placed in his way to present an effective defense for his clients and thereby protect their liberty. The judge is also frustrated. The rules of court decorum are broken. His authority, which hitherto he has taken for granted, has collapsed. The ordinary means of restoring the status quo ante, such as admonishing the attorneys or deploying the marshals, have failed to work. ${ }^{71}$ Chaos is spreading in the courtroom. "There is not much more you can say, Mr. Kunstler" is not a response to the substance of Kunstler's jeremiad. The judge says nothing in justification of his legal action. "There is not much more you can say" is a comment on how far Kunstler had gone in violating court decorum. It implies that the bright line has already been crossed. There is no additional distance to go. It may also contain a veiled threat to Kunstler: stop because you yourself are in violation of the law (of contempt); or a plea: stop, because without judicial authority there will be no liberty.

The spectators are buoyed, presumably by the lawyer's daring defiance, the intoxicating feeling of bearing witness to the act of "speaking truth to power." "Right on" they cheer and Kunstler, emboldened, does find more to say: "there is no law in this court." By now he is in a trance. To the shouts of "right on", Kunstler's chutzpah reaches its climax: "-- these men are going to jail by virtue of a legal lynching -" he exclaims, "Right on, Right on", his chorus chants, and rewards him with a round of applause.

Here the dialogue invokes one of the mythical tensions in American law: that between law and lynching, thereby appealing to collective memory. In American law lynching has sometimes been perceived as a continuation of law, a necessary supplement to it. $^{72}$ By the $1960 \mathrm{~s}$ it was a chilling symbol of violent illegality. Yet again the scene represents a twist: it is the government (the judge) who is accused of lynching, and the crowd (the mob?) who serves as the accuser. "Out with those applauders," orders the judge. Does Judge Hoffman, presently accused of legal lynching, feel lynched by Kunstler and his supporters? Are they "the mob" in his eyes?

At this moment the dialogue turns into a spectacle: in a courtroom, where the audience is expected to be passive and silent, the interaction between attorney and spectators becomes physical. Peter Brook observed that the rough theater is "a theatre of noise and the theatre of noise is the theatre of applause." ${ }^{73}$ Noise (applause) instead of rational argument takes over, and 
it speaks louder than words. A defendant joins in applauding and calls attention to himself. $\mathrm{He}$ wants to be a part of the action (fun?). ${ }^{74}$ The marshals, to whom the order "Out with those applauders" is addressed, presumably move to escort the spectators through the door. ${ }^{75}$ The judge's order, however, harks back to the literature of the absurd. It echoes the Queen of Hearts' command during Alice's trial in Wonderland, "off with her head." ${ }^{.76}$ Here the judge, angry and humiliated in his own court, contributes to the loss of his own dignity by invoking the quintessentially tyrannical Queen of Hearts, thereby, perhaps, confirming the arbitrary quality of his denial of the motion moments before. But his words show that he, too, feels that reason has been banished from the courtroom, and that the dignity of the courtroom is reduced to dependence on the might of the marshals' bayonets.

The Abernathy scene thus provides a powerful dialogue, enhanced by sound and spectacle, to illustrate the collision between two important principles of law. The presumption of innocence and its companion -- the right to explore every corner to prove this innocence in a court of law on the one hand, and on the other hand the imperative that judges are able to exercise authority and legitimacy in the execution of criminal trials. A side order of professional ethics, judicial ethics as well as the ethics of the zealous advocate who doubles as an officer of the court, is also present. A quite astonishing scene, which can shock the audience into a realization that you don't need devils to experience the fragility of the rule of law and its precious significance for civilized society. Humans will do just fine. ${ }^{77}$

In the competition between the Bolt-Gignoux and the Hoffman/Kunstler dialogues, it seems that the latter wins hands down. This, at least, I expect to be the judgment of judges like Brook, Brecht, Artaud, Kott, and Brustein.

Still, "the Abernathy scene" is mostly text. Words are its predominant tool for conveying meaning. In order truly to shock the audience into reassessing the meaning of life, Brook observed, one needed "to make ideas and images collide through words with Elizabethan force." The binding and gagging of Bobby Seale accomplished just that. I shall first analyze this scene, and then present one that is mostly spectacle with very few words attached to it -- the judicial robes incident. Each has pushed further the capacity of theater in the courtroom to shock and compel further reckoning with the meaning of law and justice. 


\section{The Binding and Gagging of Bobby Seale}

The sequence of events was as follows. After the indictments were served, all eight defendants agreed that Charles R. Garry, Seale's attorney of choice, would serve as chief defense counsel, and that William Kunstler and Leonard Weinglass would serve as co-counsels. Garry handled the extensive litigation generated by the Black Panther Party since its establishment in 1966, and had Seale's complete trust. The defendants' choice of counsel was duly and clearly communicated to Judge Hoffman. ${ }^{78}$ Days before the trial was scheduled to begin, Garry fell ill and had to undergo an emergency gall bladder operation. His request for a postponement of the trial was denied. Why?

Judge Hoffman and the prosecution were convinced that the defense was plotting to sabotage the trial through the manipulation and abuse of the laws of procedure. They interpreted Garry's request as a part of that strategy of sabotage. Hence, Judge Hoffman resolutely determined to deny any motion for continuance. ${ }^{79}$ One may see this as an extension of the government's conviction that it was facing a dangerous conspiracy.

In early September, Kunstler filed a temporary appearance as Seale's attorney in order to visit him in prison. When the trial started and after Garry's motion was denied, Judge Hoffman used Kunstler's filing of appearance to hold that Kunstler in fact was Seale's attorney. It may well be that Judge Hoffman did not differentiate among the defendants (or their lawyers) and saw all as interchangeable. Thus the Judge could conclude that from Seale's perspective one lawyer was as good as the next one, and that his insistence on Garry was a ploy rather than a legitimate and sincere position. ${ }^{80}$ It is quite clear from the record that Seale never intended to have Kunstler as his attorney and that Kunstler, abiding by Seale's will, repeatedly stated in court that he was not representing Seale. ${ }^{81}$ Meanwhile (always in contact with Garry and following his advice), Seale filed a motion to represent himself. ${ }^{82}$ The motion was denied, and Seale was sternly instructed to behave like (play the role of) a defendant, i.e., never address the judge, speak only when spoken to, or otherwise communicate discreetly with "his lawyer," William Kunstler. ${ }^{83}$

We now come to the climax of Act I: the actual scene of binding and gagging. The scene lasted for three days. Most students of American law or modern criminal law elsewhere would not recognize the technique of binding and gagging as a familiar part of criminal procedure. 
Judge Hoffman, who had many years of experience with criminal trials, stated that he was doing it for the first time. ${ }^{84}$ Yet he had legal authority to do so. Strangely enough, the idea of binding and gagging an unruly defendant was introduced in Chicago by the Seventh Circuit in the summer of 1969 as pretrial motions for the Conspiracy Trial were being processed. Surely there was no conspiracy in the fact that it was handed down on July 7, the birth date of both Judge Hoffman and William Kunstler. ${ }^{85}$ In Allen v. Illinois, the court of appeals held that an unruly defendant could be bound and gagged in open court so as to guarantee his constitutional right to confront witnesses. ${ }^{86}$ The Court of Appeals also held that such an unruly defendant might not be removed from the trial, because the right to confront witnesses was an absolute principle that should not be compromised. ${ }^{87}$

Mis-en-scène: a wood paneled, modern courtroom designed by legendary architect Mies Van der Rohe. The judge, a short and bald man, sits high on the dais. He is wearing a black robe. He looks well groomed and manicured. We know that he lives in one of the most luxurious buildings of Chicago, and that every morning before coming to court he stops at the barber shop in his building to be shaved. ${ }^{8}$ Behind the judge hang the Great Seal of the United States and pictures of George Washington, and Benjamin Franklin. In the corner stands the American flag. Twelve jurors are in the jury box, ten women and two men. Two of the women are AfricanAmerican. Eleven of the twelve are middle-class and middle-aged. Two prosecutors, Thomas Aquinas Foran and Richard ... Schultz, and one FBI officer, are seated at the table for the prosecution. They are dressed in suits and ties, their hair is cut short, and their table is impeccably clean. Around the defense table sit eight defendants, one of them African-American, and two lawyers. The lawyers are dressed in shabby jackets and ties; one of them, Leonard Weinglass, sports long hair (Kunstler's hair will grow longer as the trial goes on). The defendants wear jeans and boots, and some have colorful shirts. ${ }^{89}$ Their hair is long, many have long, untrimmed beards. Their table is cluttered with mail, papers, envelopes, newspapers, and magazines. A "young brown woman in a brown vinyl dress, wearing a full natural, startlingly pretty", sits behind the steno machine below the witness box. ${ }^{90}$ Behind the defense table there is a press section, where the representatives of the media gather, some with blocks and pencils, ready to draw scenes from the trial. A few persons, upper-middle-class by dress and look, sit next to the reporters in the front row. They are invitees of the judge or the prosecution. ${ }^{91}$ Behind 
them is the spectators' section. Many of the spectators have the look and dress of the 1960s counterculture; they come to support the defendants. The room is full of marshals, many of them African-American, standing guard at the entrance to the doors and around the defense table. The air is very tense.

This mis-en-scène is itself a Rorschach test of America in the late 1960s. Culture and counterculture collide. The government and judge stand for order, convention, and self-control; the defense for a mix of individualist philosophy ("do your own thing", or "laissez-faire") and communitarianism, reflected by their overt camaraderie and solidarity. Race, gender, and class are present. All members of the trial "team" are white males (four of the five are Jewish). Many members of the staff -- the stenographer, the marshals -- are black. With the exception of the women jurors whose presence in the trial is mostly passive, the other women in the courtroom are all in subservient positions -- as stenographer or as assistants to the defense team. The judge's upper-class demeanor is contrasted with the middle-class appearance of most of the jurors and the working-class appearance of the marshals. Age is present. The judge is 74 years old. The defendants and many of the spectators are known for the slogan "never trust anyone over thirty." But some of them are in their early to mid-thirties. ${ }^{92}$

October 28, 1969: the government is presenting its case. Its list of witnesses is studded with undercover police agents. William Frapolly is one, and his testimony continues today. Has he also been an agent provocateur? Was he employed by the government not only to spy on the dissenters but also to encourage them to engage in illegal activity? Mr. Kunstler is crossexamining the witness:

Mr. Kunstler: Mr. Frapolly, I understand yesterday you testified that you had been or were a student at Northeastern Illinois State College?

The Witness: That is right, sir.

Mr. Kunstler: Are you still a member of the student body in good standing?

The Witness: No, I am not.

Mr. Kunstler: You were expelled, were you not, for throwing the president off the stage physically?

The Witness: No, I wasn't, sir.

Mr. Kunstler: What were you expelled for?

The Witness: I was expelled for being with a group of people that threw the president off the stage.

Mr. Kunstler: Did you help to organize and plan this physical attack on the president of this university? 
The Witness: No, I did not, sir.

Mr. Kunstler: Were you participating in discussions about it?

The Witness: That is correct.

Mr. Kunstler: Now when you were participating in those discussions, is it not true that you were receiving pay from the Police Department of the City of Chicago?

The Witness: That is correct, sir.

Mr. Kunstler: Is it not true that you were instructed by the Police Department to participate in this physical attack on the president of the University?

The Witness: That is not correct, sir.

Mr. Kunstler: Now you testified yesterday that in doing this work you grew sideburns, a mustache, a goatee, and let your hair grow long, is that correct?

The Witness: That is correct.

Mr. Kunstler: Can you give some indication to the jury how life was for you with long hair and a goatee?

Mr. Foran: Objection, your Honor.

The Court: I sustain the objection.

Mr. Kunstler: Didn't you tell the grand jury how awful life was for you with long hair and a goatee in this city?

Mr. Foran: Objection.

The Court: I sustain the objection.

Mr. Kunstler: Now you started, you say, on February 13, 1968, to do this work and you kept it up until September of 1969, is that correct?

The Witness: No, sir.

Mr. Kunstler: When did you stop?

The Witness: I stopped--my cover was officially blown yesterday.

Mr. Kunstler: Oh, officially blown yesterday by your testimony, is that correct?

The Witness: That is correct, sir.

Mr. Kunstler: Now yesterday you revealed yourself to the world for what you were, is that correct?

Mr. Foran: I object to that, your Honor.

The Court: I sustain the objection. ${ }^{93}$

The question of how the government goes about its obligation to make sure that the laws are faithfully executed is presented here in full force. What should we think of undercover police agents? What do we think of those who act as agent provocateurs, urging and assisting in potential criminal behavior? How does this affect the concept of "conspiracy"? On the one hand, this is despicable behavior, as indicated by Kunstler's question. Some consider it frightening behavior, one fitting a police state, not a freedom loving democracy. After the trial, Jean Fritz, one of the jurors, told reporter John Shultz: "What was frightening to me was that there are 
young people who will go to college and let their hair grow long and then report back. What is happening to our country when your roommate in college may be reporting back to the government? When the government can tap anybody's phone? Or do anything it wants to do?" In general, such behavior is condemned as ethically wrong. And yet, in the age of Al Qaeda and after September $11^{\text {th }}$, one must face the question: is it possible for the agent to cultivate the trust of the would-be criminals without some credible pretense to "be like them?" Should "political activity" be off limits to the governmental deployment of undercover agents? To the recruitment of one citizen as agent provocateur against another? Who will defend the dissident's first amendment rights in such situations?

A more difficult issue lies underneath the phenomenon of undercover agents: the issue of trust and betrayal. In his Violence and the Word, Robert Cover quotes Victor Navasky for the proposition that informers destroy "the very possibility of a community ... for the informer operates on the principle of betrayal and a community survives on the principle of trust." 94 Cover observes that " $[\mathrm{w}]$ hile pain is the extreme form of world destruction, fear may be as potent, even if not connected to physical pain and torture." 95

Frappoly's testimony itself raises fear of the potential for abuse and lawlessness in government operations. A paradox unfolds. The purpose of the trial is to reaffirm America's commitment to law and order as a community. The means to that end is evidence obtained by secret agents. Thus the community is undermined by the very same force that tries to protect it.

Fear is further injected through the massive presence of armed police officers in uniform and in plain clothes. Those siding with the government also have a cause for fear. Young members of the Black Panther Party are very conspicuous in the courtroom. Indeed they were thoroughly searched before entering, but would they become violent?

Against this background and in the midst of this explosive atmosphere Bobby Seale rises to repeat his demand to cross-examine Frapolly after Kunstler is done:

"Mr. Seale: I would like to request to cross-examine the witness.

The Court: you have a lawyer here.

Mr. Seale: That man is not my lawyer. 
Seale recites his position that he has a constitutional and statutory right to defend himself. ${ }^{96}$ The dialogue ends with the following exchange:

The Court: I am warning you that under the law the Court has a right to gag you. I don't want to do that. Under the law you may be gagged and chained to your chair.

Mr. Seale: Gagged? I am being railroaded already. I am being railroaded already. The Court: The Court has that right and I-

Mr. Seale: The Court has no right whatsoever. The Court has no right to stop me from speaking out in behalf of my constitutional rights.

The Court: The Court will be in recess until tomorrow morning at ten o'clock.

The Marshal: Everyone please rise.

Mr. Seale: I am not rising. ${ }^{97}$

The prelude to the actual binding and gagging is already ominous. The judge warns Seale about the option of binding and gagging; Seale remains defiant, so defiant that he is even challenging one of the most sacred aspects of the conventional court theater: the respect shown to a court of law by rising when the judge leaves the room. Both judge and defendant are angry and frustrated. Both are embarking on a collision course.

October 29, 1969: Terror permeates the courtroom. Each side is eyeing the other suspiciously. What will happen next? ${ }^{98}$

Morning scene:

"The Court: Mr. Marshal, bring in the jury

Abbie Hoffman: There are twenty-five marshals in here now, and they all got guns. There's two practically sitting in the jury box.

Mr. Weinglass: If the Court please, within observation of your Honor is a phalanx of marshals literally. I believe there are ten standing in the narrow aisles leading to the doorway of this courtroom. There are three more standing at another door, one more standing at another door.

Now, the jury is about to be brought in. They will enter from that door. The first thing that they will see as they walk into this room is a group of twenty marshals standing in a very ominous posture, and I cannot begin my cross-examination of a witness. The jury cannot sit here unmoved by that.

The Court: If you don't want to cross-examine, that is up to you, sir. Bring in the jury. Mr. Kunstler: Your Honor, we are objecting to this armed camp aspect that is going on since the beginning of this trial.

The Court: It is not an armed camp.

The jury is brought in and then sent out as Seale and Judge Hoffman again cross swords about Seale's right to defend himself. 
The Court: Let the record show the tone of Mr. Seale's voice was one of shrieking and pounding on the table and shouting. That will be dealt with appropriately at some time in the future.

Mr. Seale: I have a constitutional right to speak, and if you try to suppress my ...rights, then I can only see you as a bigot, a racist, and a fascist, as I have said before and clearly indicated on the record. ${ }^{99}$

Mr. Wineglass concludes his cross-examination of witness Frapolly, and Seale repeats his demand to cross-examine the witness:

The Court: Take the jury out, and they may go to lunch with the usual order. Mr. Seale: You have George Washington and Benjamin Franklin sitting in a picture behind you, and they was (sic) slave owners. That's what they were. They owned slaves. You are acting in the same manner, denying me my constitutional rights being able to cross-examine this witness...

\section{Afternoon scene:}

The Court: Mr. Seale, I have admonished you previously -Mr. Seale: I have a right to cross-examine the witness -

The Court: -- what might happen to you if you keep on talking.

Seale and the Judge continue to argue for a brief moment until the Judge declares:

The Court: We shall take a recess.

Judge Hoffman turns to a group of three marshals poised beside Seale at the defense table and says:

Take the defendant into the room in there and deal with him in the manner that he should be dealt with in the circumstances.

Marshals carry Seale out as he shouts: "I still want to be represented. I still want to represent myself." 100

Within eleven minutes Seale is returned to the courtroom, "his hands and feet chained to a gray metal chair. A gag of muslin passed through his mouth and ... tied at the back of his neck." ${ }^{101}$ Through his gag he keeps shouting his demand to represent himself and orders Kunstler to ignore the judge's instructions to speak for him. ${ }^{102}$ Judge Hoffman addresses the marshal: "Mr. Marshal, I don't think you have accomplished your purpose with that contrivance. We will have to take another recess." Seale is carried out and is returned with "his mouth... covered by adhesive tape." ${ }^{103}$ A short interrogation of Mr. Frappoly continues with the bound and gagged 
Seale present. The court adjourns for the day.

On retrial, Judge Gignoux described the scene of the next morning:

On the morning of October 30, the marshals carried Seale into the courtroom in a chair with a massive gag covering most of his face and with his arms and legs strapped to the chair. Mr. Weinglass was cross-examining the witness Frappoly and interrupted his cross-examination to call the judge's attention to Seale, who was groaning, attempting to communicate through his gag, and apparently in considerable pain. [the straps were blocking his blood circulation, PL] The judge excused the jury and directed the marshals to determine whether Seale needed assistance. Several marshals approached Seale's chair. A scuffle ensued in which the chair tipped over, apparently into the first row of temporary press seats in the well of the courtroom. Pandemonium broke out... ${ }^{104}$

Judge Gignoux further declared the spectacle "appalling" and opined that "the trial proceedings had so disintegrated... that no judicial proceeding could fairly be said to be in progress." 105 Judge Gignoux had a reason to decide that it could not "fairly be said" that any judicial proceedings were taking place, a very delicate way of saying these were a far cry from the conventional mode. Such a preliminary finding facilitated his decision that the defendants and their lawyers should not be held in contempt of court for anything they said or did during this scene. ${ }^{106}$ From the concrete historical perspective, however, this was a judicial proceeding, indeed, judicial proceeding run amok, one that turned the tables on any expectation ordinary individuals might have. The conventional theater taking place every day in every court in the nation -- the court ritual as we know it -- was falling apart. But this is precisely why this scene is so disturbing. Why it cannot disappear by simply labeling it "no judicial proceeding."

The bound and gagged Seale is rough theater, frightening and grotesque at the same time. It is also a powerful commentary about the law. Before our very eyes the medium becomes the message. The secret of its power is in the potent combination of this extraordinary spectacle with the mis-en-scene, the reaction of other players in the courtroom, the interaction between them and the mixture of text and action. I cannot think of a scene more stunning than a bound and gagged defendant, trying to communicate, through his gag his demand to have his constitutional rights recognized, while the judge and the prosecutors pretend to continue business as usual.

I have dwelled on the mis-en-scène, and shall now focus on the spectacle of the bound and gagged Seale. I shall then move to review the interaction between other actors on the stage 
or in the courtroom. Let me add that, during the discussion of the spectacle that is to follow, one should keep in mind the simultaneous presence of at least five interacting groups (choruses?): the jury, the marshals, the defendants, the attorneys, and the record. To these one should add a sixth: the invisible and yet very present Charles R. Garry. ${ }^{107}$

\section{Spectacle as the Ultimate Theater in the Courtroom}

With the exception of the Eichmann Trial, where a defendant was put into a glass booth and was thus under the total control of the government, I cannot think of a more powerful scene that depicts the defendant as an "other." Seale is formally administered justice, and yet he is visibly different from any other person in the courtroom, including the other defendants. ${ }^{108}$

The most amazing aspect of this spectacle is that it was engineered by the court itself and, by extension, by the government. Six days prior to the spectacle, Judge Hoffman announced that he was not running a circus. By that he meant to draw a sharp distinction between the theatricality of courts (high theater) and the low theater generally associated with mere entertainment. In the binding and gagging of Seale, Judge Hoffman himself turned the courtroom into what Peter Brook would call rough theater ${ }^{109}$ or a chamber of horrors.

This is interesting for several reasons. First, not the antics of the defendants brought about this most memorable spectacle, but rather the deliberate decision of a highly respected member of the federal judiciary. ${ }^{110}$ Second, the scene, indeed, reflects a wrestling between high theater -that of conventional courtroom procedure -- and low or rough theater. The twist is in the fact that it is the judge himself who resorts to the method of the rough theater, precisely for the purpose of terrorizing the defendants into obeying the conventional courtroom ritual. ${ }^{111}$ Third, the act is fiercely symbolic. The government has put on trial the most conspicuous leaders of the dissent movements in the United States for a conspiracy to cross state lines with the intent to incite a riot. It thereby walked on a precipice below which lay tyranny and suppression. A paradox was thus enacted: cherished principles of fairness have to be compromised in order to preserve orderly democracy.

The bound and gagged Seale was the embodiment of what the government was trying to accomplish. Judge Hoffman's action, in the first act of the Trial, repeated the government's action, enacting on stage the judiciary's collaboration with the determination to muzzle and 
restrain. In the introduction to this paper I suggested that two themes interact in this trial: the government effort to suppress dissent, and judicial behavior or legitimacy. The bound and gagged Seale personifies both themes at one and the same time.

Thus the Seale incident serves as a graphic illustration of the powers of government. The power to put up a major spectacle belongs to the government, not to the defendants or the media. The defendants may engage in behavior that disrupts the process (raising a clenched fist, blowing a kiss to the jury, refusing to rise when the court opens and closes). Within the subculture of sadomasochism, ordinary individuals bind and gag each other -- legally (if they are consenting adults), or illegally -- but always in private. ${ }^{112}$ The media may offer fabricated spectacles in the private marketplace. ${ }^{113}$ Inside the courtroom, the domain of officialdom and the sanctum sanctorum of truth and justice, only the government through its branch, the judiciary, can display such a scene. Only the state, perhaps only the courts, can bind and gag a human being against his will, in public, for all to see.

At this moment, and as the marshals are executing the orders of the judge and the prosecutors mostly silently acquiesce in the proceedings, the fragility of the idea of the separation of powers is too obvious not to be shocking. The purpose of the principal idea of the separation of powers, so central to the American system of government, is to prevent tyranny. In this scene, under the pictures of the founding fathers and the Great Seal of the United States, a man is denied basic dignity and the system itself falls into indignity, helpless. ${ }^{114}$

In Discipline and Punish, Michel Foucault observed the emergence of a "whole new morality concerning the act of punishing" in the modern criminal justice system. ${ }^{115}$ It was a morality "intended to apply the law not so much to a real body capable of feeling pain as to a juridical subject... It had to have the abstraction of the law itself." 116 The binding and gagging of Seale was presented as a means to maintain order and decorum and prevent a disruption of the trial. As such, it was wholly unrelated to punishment. And yet, the scene returned "the body" into the courtroom in a style reminiscent of the $18^{\text {th }}$ century practice described by Foucault.

At this juncture, the power of the scene as theater lies in its depiction of judicial discretion in the making. It forces one to reflect on the process by which a judge exercises discretion. Indeed, at that point in the trial, binding and gagging was a legitimate option. But even if Judge Hoffman felt (which he obviously did) that it would be a big mistake to give in to Seale's demands and allow him to represent himself, he could still declare a mistrial (which he 
did do after enduring two-and-a-half days of this spectacle). Are there certain acts which, even when legal, should not be performed? This appears to be the judgment of the courts reflecting in hindsight on the Seale scene. But such a practice seems to strain further the meaning of legality. As such, it is a powerful illustration of the destructive potential of "means of last resort."

The Seale incident teaches that it is not possible to bind and gag a person and yet give him a fair trial. There is nothing more grotesque than to tell a person, bound and gagged, shouting and screaming and trying to regain control of his body, that all of this is done in order to preserve his constitutional rights. Consider Judge Hoffman's statement, made in the presence of pictures of the founding fathers, the Great Seal of the United States, and the American flag, addressed to the bound and gagged Seale: "Mr. Seale, not only Sixth Amendment rights, but all of your constitutional and statutory rights, have been and will be preserved in this trial."117 One is pressed to ask: is Judge Hoffman cynical? Hypocritical? Or simply out of touch with reality?

Another important question raised by the spectacle in a way much more powerful than any abstract presentation is that of punishment and its dirty, generally hidden cousin, torture. ${ }^{118}$ Formally, the binding and gagging in Act I was not punishment and could not be punishment. Seale was formally shielded by the constitutional presumption of innocence. The problem is that while the act may not be intended as punishment, it does it look like one. ${ }^{119}$ It may arguably be cruel and unusual punishment. Cruel because Seale evidently was in great physical pain as his blood circulation stopped, his limbs went numb, and his temperature went up. ${ }^{120}$ Unusual as Judge Hoffman himself declared that "unusual and extraordinary things" were happening in the courtroom, referring to the binding and gagging. By his own testimony, this was the first time in his long career that Judge Hoffman would resort to such measures, so unusual were they. ${ }^{121}$

The deterrent function of punishment comes to mind. Are we witnessing the consequences of misbehaving in a court of law? Is this what awaits us if we, too, misbehave? The question of revenge is present, drawing attention to the close relationship between deterrence and revenge, if not in theory then in practice. It is quite probable that the judge concluded that a mistrial was inevitable, but that prior to mistrial he would take his revenge on this unruly defendant who humiliated him publicly.

This interpretation, that instant punishment (and the Court of Appeals did opine that Judge Hoffman's treatment of Seale was vindictive ${ }^{122}$ ) may have influenced the decision to bind and gag, becomes more forceful when we consider the full sequence of the scene. Seale was 
bound and gagged in the afternoon. In the morning of that day, before the court came into session, in an atmosphere of an impending storm, Seale addressed his supporters among the spectators. He told them that if attacked they should defend themselves. ${ }^{123}$ One of the major themes of the Black Panther Party, and one of Seale's most cherished principles, was the principle of the black person's right of self-defense against the white persons' violence. For Seale, as for the Black Panthers, physical power was an important component of self-dignity. When the court went into session, Seale launched an attack on America's founding fathers, referring to them as slave holders and therefore morally blemished. He was thus committing the ancient crime of lese majeste in open court. ${ }^{124}$

The spectacle of a bound and gagged Seale reflects a reflexive determination on the part of Judge Hoffman to show publicly what happens to those who insult revered leaders and think that self-defense is a right to be exercised against the judiciary. The "defanged" and incapacitated dragon (Chairman of the Black Panther Party for Self Defense) displayed helpless before his followers, his family, indeed the entire world, demonstrates in rem the limits of selfdefense. ${ }^{125}$ From this perspective, justice in the American federal courtroom of the later 1960s was reduced to a pure "eye for an eye." The humiliation of the judge begat the humiliation of the defendant and the quest for self-representation in court (self-defense) was trumped by the judicial defense of its now enforced dignity, to no avail.

To some, especially in the American context, the most powerful aspect of the spectacle may be its racist appearance. ${ }^{126}$ Seale was the only African-American defendant on trial. ${ }^{127}$ His binding and gagging invoked the image of slavery. Having black marshals publicly perform the task of binding and gagging raised the specter of America's Uncle Toms. Thereby, theater in the courtroom did exactly what good theater was supposed to do: connect the event on the stage with history and culture, graphically demonstrating the link between past and present. The possibility that not much has changed by 1969, that a black person was still denied constitutional rights, and that other blacks were assisting the master race in reining in the troublemakers, is very explicit in this scene.

But the spectacle of binding and gagging goes further than raising the specter of American slavery. Its dramatic power lies deeper in its ability to invoke ancient and universal myths. Both the Greek Prometheus and Christ were crucified by the forces of tyranny. Both seem to be present in this scene. ${ }^{128}$ I shall focus mainly on Prometheus, the quintessential 
rebel who defied the decision of the gods to keep humankind in its primeval animal condition. Seale's defiance against the "established order," his insistence on his right to have the counsel of his choice against tremendous pressure by the judge and the court system, even at the price of his public torture and humiliation, invokes the Promethean myth. Seale's rebellion against the established order in the United States comes to a climax when he attacks the founding fathers as racists ("they were slave holders"). His challenge of the patriarchal order, both that of Judge Hoffman himself ("patriarch of the court"), and George Washington ("father of the republic"), had now become complete. ${ }^{129}$

In the Greek myth, the gods enjoy the blessings of fire (knowledge), but deny them to humankind. ${ }^{130}$ Prometheus takes the fire and shares it with men and women. In the Seale scene, an African-American rebel insists that the same sixth amendment rights that the founding fathers arrogated to themselves be extended to him as well. He translates selfdefense outside of the courtroom to legal defense inside it. He insists that his people are equally able to use the rights conferred upon them by the constitution:

Mr. Seale (to Judge): You think black people don't have a mind. Well, we got big minds, good minds, and we know how to come forth with constitutional rights... Black people ain't supposed to have a mind? That's what you think. We got a body and a mind. ${ }^{131}$

And yet, there were deeper layers to the story. Seale was not only a victim, but also an active manipulator of the scene, following the advice of his invisible lawyer, Charles R. Garry. Garry was in constant communication with Seale and advised him to refuse to accept Kunstler's offer to represent him and insist on his right to represent himself. Garry conceded that, "We forced the situation that gagged Seale. We expected the gagging and shackling long before it happened." 132 There were several reasons for this. First, Seale wished to highlight the struggle of a lone black man against the entire "white racist system." For this reason, he insisted that the other defendants don't join in symbolically chaining and gagging themselves. ${ }^{133}$ Secondly, attorney Garry, who was also contemplating Seale's pending trial for murder in Connecticut, was hoping that escalating the scene into binding and gagging would facilitate an argument on appeal that the trial was devoid of due process. ${ }^{134}$ This perspective, adding the spice of Brechtian alienation to this scene, is very important. Judge Hoffman initiated the scene and stood to benefit from it by inflicting instant revenge on seale, and proving "who is the boss" in the courtroom. 
Yet the scene also proves the manipulability of Judge Hoffman, the governor of the trial, and the means "victims" retain to benefit from even the most rigid and powerful system.

\section{Other Players and Other Techniques Interacting with Spectacle: Pantomime, Action, Text}

As I indicated above, the power of the gagging and binding scene comes not only from the spectacle itself, as stunning as it is, but also from the interaction between the various actors: the jury, the marshals, the defendants, the attorneys, and the record. It also rests on the interaction between theatrical methods: pantomime, action, and dialogue.

The Jury: One of the most important institutions in the American system of criminal justice, the jury is expected to be silent in court. Jurors use their eyes and ears, absorb the information and make important decisions; but in the courtroom they are silent participants. In the transcript, the jury is only mentioned when it leaves and returns, obeying the judge's orders. ${ }^{135}$ Because this happens very often in this trial, the coming and going by itself becomes a part of the theater and is vested in meaning. One gets the impression of constant waves of movement, with justice surviving in the pockets of intervals when the jury is actually in the courtroom. One is forced to reflect on the relationship between truth and justice, between law's peculiar distinction between the relevant and the irrelevant. If the trial is about the search for truth, why is the jury denied the information? If justice requires the suppression of information, what is the meaning of truth? The jury plays multiple roles. It is at once spectator and actor. But from the perspective of the larger audience, the jury's appearance and disappearance serve as a reminder that guilt and innocence is determined by an intensely engineered body of "the truth".

But let us return to the scene itself. On the afternoon of October 29, when the jury first lay eyes on the bound and gagged Seale, Judge Hoffman addressed its members:

Ladies and Gentlemen of the jury, I must tell you that in a trial by jury in a federal court in the United States, the judge is not a mere moderator under the law but is the governor of the trial for the purpose of assuring its proper conduct, and fairness, and for the purpose of determining questions of law. The law requires that the judge maintain order and to take such steps as in the discretion of the judge are warranted, and accordingly, the marshals have endeavored to maintain order in the manner you see here in the courtroom... I direct you, ladies and gentlemen of the jury, not to hold it against any of 
the seven other defendants when these measures are taken with respect to the defendant Mr. Seale. These measures indicate no evidence of his guilt or lack of guilt of the charges contained in the indictment. These measures have been taken only, as I say, to ensure the proper conduct of this trial which I am obligated to do under the law. ${ }^{136}$

In his public speech in addressing the jury or the marshals, Judge Hoffman does not mention the terms "bind and gag." 137 He uses the euphemism "measures taken" instead. But the jury sees and, in pantomime -- in gestures rather than speech -- reacts not to abstract "measures" but to the sight of Seale himself. In Motion Will Be Denied, John Shultz described the reactions of the jury:

Mrs. Jean Fritz began weeping and other jurors squirmed hard in their seats at the sight. The brown woman who wore a red wig - she would vote for conviction on all counts during the jury's deliberations - refused to look at Seale. The other black woman, Mary Butler, who would vote for acquittal, was visibly upset and stole glances at Seale, wincing each time she saw him. Seale noticed the tears going down Mrs. Fritz's cheeks. He moved his gagged- and- bound head. ${ }^{138}$

Thus, the jury that is supposed "to see, digest and then interpret", communicates its feelings through its body movements, silently. ${ }^{139}$

The Marshals: The marshals are instrumental in executing the scene. They wear police uniforms, not robes, and represent law enforcement, not adjudication. Their function is to protect those present in the courtroom and preserve order and decorum. Judge Hoffman could not have accomplished the binding and gagging by himself, nor did anyone expect him to. He was giving orders from the bench, carefully choosing sterile, neutral, yet ominous language: "Take that defendant into the room in there and deal with him as he should be dealt with in this circumstance. $" 140$

The collaboration between the judiciary and the police itself becomes a public spectacle, again invoking an ancient myth. In Prometheus Bound, Aeschylus places two demons, Might and Violence, as supervisors of Prometheus' binding. They are servants of Zeus -- God, King of the Universe and judge:

Might: Hurry now. Throw the chain around him that the Father may not look upon your tarrying. Hephaestus: There are the fetters, there: you can see them. Might: Put them on his hands: strong, now with the hammer: strike. Nail him to the rock. Hephaestus: It is being done now, I am not idling at my work. 
Might: Hammer it more; put in the wedge; leave it loose nowhere. He's a cunning fellow at finding a way even out of hopeless difficulties.

Hephaestus: Look now, his arm is fixed immovably!

Might: nail the other safe, that he may learn, for all his cleverness, that he is duller witted than Zeus. ${ }^{141}$

But there is more. Seale proves to be a most defiant object. He struggles with the marshals and prevents them from presenting him as a properly tied and silenced "sacrificial lamb." Pressured by the judge to "produce results," and in all probability frustrated and nervous about doing in public what they usually do only behind closed doors, the marshals do what police officers do best - apply more force. It is thus that the scene turns into a public torture show.

Seale is first "pushed into his seat" after the Court orders the marshals to "have him seated." (He was standing in order to assert his right to interrogate the witness.) ${ }^{142}$ Defendant David Dellinger, who tries to help Seale after he was kicked in the groin, receives the same treatment himself, all in open court. ${ }^{143}$ On the next day, the first afternoon of binding and gagging, a marshal's elbow is pushed into Seale's mouth in an effort to silence him. ${ }^{144}$ Seale may have been beaten, as well as almost choked by the gag. ${ }^{145}$ Here is Seale's own description of his experience:

They had four large, thick belts which were bolted with special key-and-lock attachments at the buckles. My legs were both strapped tightly by Goliath. Nummy, another marshal, was securing my wrists and forearms to the chair, as another one, Arizona, who was wearing doctor's rubber gloves, gagged me. Arizona then took a stretch-type cloth bandage wrapping and wound it around and around my head, over my mouth, the back of my neck, my ears, and under my chin; it gripped my vocal cords like a vice.

God damn these motherfuckers. My breath was short and faint, and I couldn't even gesture to tell these bastards. Goliath began double-checking the straps on my arms, finding them, in his opinion, too loose, so he began to redo them, tightening them. I could feel the loss of blood circulation in my hands. I shook my head vigorously indicating that they were too tight, but Goliath smiled and paid no attention to me. As I wiggled my head, the stretch wrapping got tighter and tighter -- my whole face felt trapped. This son of a bitch -- I cursed him in my mind.

Goliath proceeded to retighten the belts around my legs, squeezing the life out of me, then started tightening again the knot at the top of my head. I started shaking my head, but the stretch bandage got tighter and tighter. Slim and Goliath picked up the chair, carrying me into the courtroom.

Suddenly, I was being lifted up into the air a couple of feet. Another white marshal rushed in. A stray elbow struck me right in my testicles. That hurt like hell. In those seconds of stumbling, balancing, bumping confusion Goliath suddenly got the bright idea of helping to pick up the chair which was then raised more than five feet in the air. I could 
damn near look directly into Judge Hoffman's eyes, when Goliath suddenly lost his balance, sending the whole team of marshals out of control and heading straight for the floor.

Their weight carried me with them, sitting high in the air strapped to the God damn chair looking down on their heads, then sailing through the air, thudding into the metal-foldingchair press section. Press people scrambled frantically to get out of the way of this oncoming disaster. And me, I was right in the middle of all that shit, hitting the floor fast and hard as I struggled, trying to grab the gag with one sort-of-loosened hand. ... ${ }^{146}$

The theme of the National Democratic Convention in Chicago is thus replayed in Act I: police brutality is the means through which the state tries to restore law and order.

The marshals' conduct falls in between the speaking actors (attorneys, defendants, and spectators) and the jury. They are not silent, yet every time they speak one is reminded whose will moves them. At this point, the reader may remember that the transcript tells us that one of the (speaking) marshals was Mr. Gracious. Had he not spoken we would not know his name. In general, marshals in the courtroom are anonymous. The marshals are the robots of the courtroom. When they speak, they merely repeat the judge's orders, thereby emphasizing the fact that they only execute another's will. ${ }^{147}$ But when they act (as distinguished from speak), they gain independence, using levels of violence that one may surmise the judge is neither familiar with, nor aware of. This is the dirty underground of the system of justice that judges are generally spared, displayed in the courtroom for all to see.

Robert Cover explained this phenomenon in Violence and the Word:

When judges interpret, they trigger agentic behavior within just such an institution or social organization. On one level judges may appear to be, and may in fact be, offering their understanding of the normative world to their intended audience. But on another level they are engaging a violent mechanism through which a substantial part of their audience loses its capacity to think and act autonomously. ${ }^{148}$

The drama intensifies when the judge's attention is directed to the "discomfort" (a euphemism for suffering, this time used by defense attorney Weinglass ${ }^{149}$ ) of Seale. Usage of euphemistic language by the defense attorney is again instructive. Here Mr. Weinglass is acting as an officer of the court, and is careful not to upset the judge's presentation of the reality. By now, Seale appears to Judge Hoffman as an object, and he orders the marshals to use measures that will silence Seale completely. This is the meaning of his instruction to the marshals:

The Court: Mr. Marshal, I don't think you have accomplished your purpose by that kind of a contrivance. We will have to take another recess. ${ }^{150}$ 
At this point one must distinguish binding from gagging. It is clear that the marshals used more force than was needed in binding Seale. Enough is known about binding (and was surely known by 1969) to expect it to be accomplished without causing the bound person unnecessary pain. There must have been more than iota of sadism and fury in the treatment of Bobby Seale on October 29, and October 30, 1969. ${ }^{151}$ However, it is not clear that gagging could have been accomplished without causing pain. Total silencing (required in an orderly courtroom, and ordinarily accomplished voluntarily) may be coerced only by means that stand in stark contrast to the values underlying the concept of law: reason and persuasion.

The Defendants, the Attorneys, the Judge: We may finally add the last piece to the tableau of the binding and gagging scene: the frenzied interaction between the parties present in the courtroom (on the stage). We have already seen Judge Hoffman interacting with the jury, the marshals and Seale. We now watch him simultaneously interacting with the defendants, their attorneys and the prosecutors. Only when one takes into consideration these multiple fronts and multiple plots can one appreciate the scene's extraordinary richness. We can also understand better the enormous pressure that the judge is experiencing. One may also hypothesize that this is a major cause of his failure to exercise discretion properly. In military theory this may be called 'the fog of battle.' Consider the following exchange on the morning of October 30, 1969:

Mr. Kunstler: Your Honor, are we going to stop this medieval torture that is going on in this courtroom? I think this is a disgrace.

Mr. Rubin: This guy is putting his elbow in Bobby's mouth and it wasn't necessary at all. Mr. Kunstler: This is no longer a court of order, your Honor; this is a medieval torture chamber. It is a disgrace. They are assaulting the other defendants also.

Mr. Rubin: Don't hit me in the balls, m..... f.....

Mr. Seale: This m..... f..... is tight and it is stopping my blood.

Mr. Kunstler: Your Honor, this is an unholy disgrace to the law that is going on in this courtroom and I as an American lawyer feel a disgrace.

Mr. Foran: Created by Mr. Kunstler.

Mr. Kunstler: Created by nothing other than what you have done to this man.

Mr. Hoffman: -being a defendant - You come down here and watch it, Judge.

Mr. Foran: May the record show that the outbursts are the defendant Rubin.

Mr. Seale: You fascist dogs, you rotten, low-life son of a bitch. I am glad I said it about Washington used to have slaves, the first President.

Mr. Dellinger: Somebody protect him.

Mr. Foran: Your Honor, may the record show that it is Mr. Dellinger saying 'Someone go to protect him' and the other comment is by Mr. Rubin. 
Mr. Rubin: And my statement, too.

The Court: Everything you say will be taken down. ${ }^{152}$

This is a climatic moment. The nervousness is so great that while the participants are trying to express themselves, dialogue has completely broken down. Everyone is speaking at the same time, the participants do not hear each other or when they do, they fail to listen. They speak past each other, each hopelessly locked in their own world-view and concern. Kunstler urges the court to "stop this medieval torture chamber", using language which clearly antagonizes the judge further. Unlike his co-counsel, Mr. Weinglass, who carefully used the euphemism "discomfort", Kunstler opts for a bold approach, thereby challenging the conventional expectations from an officer of the Court. Foran, the chief prosecutor implicitly agrees that the sight is a disgrace, but lays blame on his adversary: "created by Mr. Kunstler." The defendants, closest to Seale, call upon the judge to become a witness: "You come down and watch it judge" (by Abbie Hoffman, another way of saying that law in the books and law in action may be very different things). They also address the jury, another faux pas in a conventional trial. ${ }^{153}$ As they protest, they themselves become the targets of violence. A cry is heard: "Don't hit me in the balls, m...f..." The prosecutors, seeking to assign blame and secure punishment, assume the role of bookkeepers, collecting evidence of contempt of court by the defendants. "Mr. Foran: Your Honor, may the record show that it is Mr. Dellinger saying, 'Someone go to protect him', and the other comment is by Mr. Rubin."

Language as an instrument of communication is another salient part of the scene. Legal language is always distinct from colloquy, and Judge Hoffman went further when he wrapped his speech with euphemisms that concealed the violence sanctioned by his words. In his interaction with Seale, one further sees how language served as a curtain to protect the judge from the harsh reality of everyday life. Judge Hoffman found Seale's vernacular offensive and unacceptable. He took the words "pig" and "fascist," quite common among members of the counterculture, as a personal insult. He was likewise not amused by the term "motherfucker", and in the trial transcript he refused to spell it out. ${ }^{154}$ Here is his dialogue with Seale's representative, following Seale's conviction of contempt of court:

The Court: But you don't call him [the judge] a pig and a fascist in the process of disagreeing with him. 
McTernan: What I wanted to get to is this: ... we were dealing with a black man who comes out of a black ghetto.

The Court: You are the one who brings out this black man thing again... why mention color?

McTernan: Because it has to do with the words he used, your Honor. It has to do with the culture from which he comes and the meaning ascribed to words. That is what I want to address myself to.

The Court: I have known literally thousands of what we used to call Negro people, and who are now referred to as black people, and I never heard that kind of language emanate from the lips of any one of them... there is no evidence here in this case that it is part of a culture.

McTernan: Your Honor, that is precisely the point I am getting to. Of course there is no evidence here, but there should be. There should be before a man is sentenced to of four years in jail for contempt for use of language. ${ }^{155}$

The judge desperately clings to his view of the world: he is in favor of formal equality and color blindness. Seale's request for the recognition of "difference", an acceptance of the fact that in some pockets of America the judge and policemen are thought of as "pigs", is not something he, as a public official, can accept. Again, the scene highlights the gap between himself and the defendants, between the culture and the counterculture.

If one were to analogize this scene to an orchestral performance, one could marvel at the way in which each instrument is pursuing its own tune and at the great disharmony that is accomplished. ${ }^{156}$ More interesting, however, is to reflect on the judge as conductor. In general one may think of a judge as a conductor, the governor of the trial (as Judge Hoffman was fond of reminding his audience) who synchronizes the various conflicting parts and interests represented in the courtroom. But here it seems that the judge has lost perspective of the bigger picture or of its most pertinent part. The cacophony has affected him too, and he is reduced to contemplating revenge, through the creation of a record of contempt, responding to what, given the gravity of the scene, are rather petty requests by the prosecution: "Everything you say will be taken down." This comment takes us to another actor in this drama: the record.

The Record: The record, here created by an African American woman, ${ }^{157}$ is an important element of a trial. It is the embodiment of neutrality and objectivity. The reporter is not expected to inject her values into the act of recording, but to record whatever transpires during the process. On the basis of the record, which is presumably impartial, will the courts of 
appeals and of history judge the facts. It is interesting to witness how this trial's record is being created and why. With the benefit of hindsight, it is clear that Judge Hoffman was preparing the grounds for massive contempt convictions accompanied by heavy sentences.

However, the interesting aspect of this record is not so much the long-term goal of the judge, but rather the twist introduced by the defendants. During his exchanges with the judge Seale was the first to make use of the record. His verbal interventions were not only attempts to claim his constitutional rights or to interrogate the witnesses, but also to create a record:

Mr. Seale: If you let me defend myself, you could instruct me on the proceedings that I can act, but I have to just The Court: You will have to be quiet.

Mr. Seale: All I have to do is clear the record. I want to defend myself in behalf of my constitutional rights.

The Court: Let the record show that the defendant Seale has refused to be quiet in the face of the admonition and direction of the court.

Mr. Seale: Let the record show that Bobby Seale speaks out in behalf of his constitutional rights, his right to defend himself, his right to speak in behalf of himself in this courtroom.

The Court: Again let the record show that he has disobeyed the order of the court. ${ }^{158}$

While the judge documents the alleged contempt (and at the same time warns the defendant not to repeat the disruption) Seale is holding a mirror before the judge. He is showing that he too can use the record in order to lay the grounds for his claim that this is not a fair trial. It is here that the significance of the record as an almost impartial (but not quite; see below) instrument of the rule of law is manifested. The defendant is thereby empowered to defend himself in this passive manner, even if the judge prohibits him from representing himself in the trial.

Moments before he is removed from the courtroom to be bound and gagged, Seale again tries to create a record (memory), but this time only his effort is recorded, not what he was trying to say:

The Court: The court will be in recess for a few minutes.

Mr. Seale: Let the record show that -

The Marshal: This court will take a brief recess.

Mr. Seale: Let the record show -- 159

The record thus bears testimony to the imbalance of power in the courtroom. Seale's unfinished sentence, twice repeated, hangs in the air, inviting us to imagine what he was wishing 
to record. Other defendants also seized on this technique. On October 28 (the day before he was bound and gagged), Seale addressed the judge:

You are the one in contempt of people's constitutional rights. I am not in contempt of nothing. You are the one who is in contempt. The people of America need to admonish you and the whole Nixon administration.

The following was recorded:

Mr. Hayden: Let the record show the Judge was laughing

Mr. Seale: Yes, he is laughing.

The Court: Who made that remark?

Mr. Foran: The Defendant Hayden, your Honor, made this remark.

Mr. Seale: And me.

The Court: Let the record show that --

Defendant Tom Hayden used the record in order to document emotion displayed by the judge, something the record ordinarily ignores. The judge was laughing. That was particularly important because Judge Hoffman previously admonished the defendants to maintain the serious atmosphere of the courtroom and refrain from laughing. ${ }^{160}$ Hayden was trying to apply the rules of decorum to the judge himself (thereby reminding the audience that the judge is not only accountable but also serves as an example to others). However, the impudent statement of Seale, combined with the judge's laughter and Hayden's bold intervention, created a burlesque atmosphere which prompted Seale to add: "and me too."161 This last statement does not seem like a calculated statement to create a record, but rather a breakdown in self-restraint in an effort to "join in the fun." After two days of intensive drama, as respect for the judge diminished and chutzpah increased, the record began to suffer from overuse and lost its special status.

\section{As the Curtain Falls}

After two and a half days of binding and gagging, the Judge allowed Seale to appear in the courtroom free of binds and gags. Reporter John Shultz described the scene: "All over the courtroom marshals put into their pockets badges and other obvious things that might be grabbed in hand-to-hand fighting. The courtroom was jammed, with the exception of the empty jury seats along the north wall." "162 The reading of Seale's certificate of contempt lasted two hours. For the 
second time during the trial, Judge Hoffman displayed his talent for acting, thereby conceding the relationship between trial and theater:

With mimic powers that could chill a listener, with the eerie reality of Seale's voice in his voice, Judge Hoffman, read the sections of the transcript for each of the sixteen instances of contempt... The only voice that the judge missed in the transcript was his own voice. He always read it so mildly, particularly when it was a dialogue in which he was admonishing Seale. ${ }^{163}$

John Shultz' observation about the "mild" (reasonable?) tone used by the judge in the repeat performance is interesting. It implies that the judge's tone during the "real incident" was very different, presumably the opposite of "mild." Given the description of the "pandemonium" one may imagine this to be true. The important point here is that, in Judge Hoffman's performance commenting on the theater that preceded it, we get a chance to hear how Judge Hoffman experienced the proceedings he was describing. He did not see himself as one who has lost his tempter, but rather as mild and even-handed, as judges typically ought to be. Only theater can convey this gap between the ideal, reflected in the judge's reading, and the reality that preceded it. The record is silent text. Reading aloud can convey the emotions in real time and their remembrance afterwards. There is, however, more to this episode. In accordance with court ritual, the judge pauses between conviction and sentencing, to hear the defendant:

The court: I Mr. Seale, you have a right to speak now. I will hear you.

Mr. Seale: For myself?

The Court: In your own behalf, yes.

Mr. Seale: How come I couldn't speak before?

The Court: This is a special occasion.

Seale's reaction seems to be the typical wonder of those unschooled in the ways of the law. He naively reveals the paradox: he was fighting for a right to speak in behalf of himself, and now he is patronizingly told that as a "special occasion" he may do so. As Seale prepares to launch yet another plea to be heard as a defendant in the conspiracy trial, Judge Hoffman hastily declares the sentence. Seale will serve in prison for four full years, three months in prison for every specification of contempt. Judge Hoffman concludes with a surprise:

The court: In view of the disposition of this aspect of the case, there will be an order declaring a mistrial as to the defendants Bobby G. Seale and not as to any other defendants.

Mr. Seale: Wait a minute - what's the cat trying to pull now? I'm leaving - I can't stay? The Court: The court will be continued until tomorrow morning. 
Mr. Seale: I still want an immediate trial. You can't call it a mistrial. I'm put in jail for four years for nothing? I want my coat."

Jason Epstein describes the finale: "Then as the marshals dragged him through the door into the lockup he looked back at his chair and noticed that he had left something behind. 'I want my coat,' he called out as the lockup door closed behind him. 'Free Bobby! Free Bobby!' cried the spectators. The voice of the marshal announcing a recess for the day was lost in the shouting." 164

It now becomes clear why the marshals were removing their badges in anticipation of violence in the courtroom. The judge decided to declare a mistrial because Seale's insistence on his rights was too disruptive, and the binding and gagging proved intolerable. But first he needed to give Seale his comeuppance - a stunning sentence of four years in prison. He saved the declaration of a mistrial to the very last moment for he expected Seale and other defendants to be very upset and feared that violence may erupt. Seale, unprepared for this development, was forced to face the grim reality. As the marshals dragged him out of the courtroom he remembered his coat. Winter was descending on Chicago and the jail was very cold. The apparatus of the state was proven mightier than he. He now needed to shield himself against the powers of nature and worry about basic survival. A coat was an important instrument in this battle.

\section{Defendants Wearing Judicial Robes in Court}

On the morning of February $6^{\text {th }}, 1970$, minutes after the court came into session, Abbie Hoffman and Jerry Rubin (Abbie and Jerry) entered the courtroom in judicial robes. Onto the robes they pinned the Jewish yellow star. In front of the robed judge and the jury, the two removed the robes, threw them on the floor, stepped on them and used them to wipe their feet. Abbie had a further surprise: underneath his robe he was wearing the shirt of a Chicago police officer. No actual disruption occurred. The two took their seats at the defense table, the judge had a brief exchange with Kunstler, and the trial proceeded. Thus this was a scene of almost pure spectacle. Eyes may have rolled, disgust could have been registered on some faces and delight on others, but few words were uttered, no dialogue took place and no further action was taken. In 
terms of theatrical performance, one may analogize this scene to an African or Asian dance, with the dancer making a masked appearance, proceeding with quick stylized gestures to remove the mask and reveal the human face. ${ }^{165}$

Flashback: on the second day of the binding and gagging of Bobby Seale, as the marshals were applying force to keep Seale bound and gagged, the trial transcript reports:

Mr. Hayden: Now they are going to beat him, they are going to beat him...

Mr. Hoffman: you may as well kill him if you are going to gag him. It seems that way, doesn't it? ...

The Court: You are not permitted to address the Court, Mr. Hoffman. You have a lawyer...

Mr. Hayden: ... I was trying to protect Mr. Seale. The man is supposed to be silent when he sees another man's nose being smashed?

Mr. Hoffman: The disruption started when these guys got into overkill. It is the same thing as last year in Chicago, the same exact thing."

Abbie Hoffman experienced the trauma of the Democratic Convention in Chicago as reenacted on the court's stage in the binding and gagging of Bobby Seale. The Walker Commission investigating the events during convention week determined that police behavior amounted to a "police riot." ${ }^{167}$ Abbie observed the very same brutality in the treatment of Seale. Except there was a difference. During the events in Chicago, the police was acting as the arm of the executive branch; the scene at the courtroom was performed pursuant to the judge's orders, under the eyes of the judge as the embodiment of "the law" and with his full cooperation, even encouragement. If the judicial robes are a symbol of the law, then the scene of the judicial robes, strategically displayed at the end of the trial, perfectly captured the defendants' experience of its meaning and its message. ${ }^{168}$

David Mamet observed that a knife appearing in the first act of a drama would reappear in the last act as an "attempt of the orderly, affronted mind to confront the awesome; to discover the hidden structure." 169 It was dramatically fitting that Abbie and Jerry, the court's jesters, the clowns in this trial, would author the final spectacle, provoking thought on the meaning of the administration of justice in general, and in this trial in particular. For a moment before the end, the defendants appeared as judges (wearing judicial robes), expressing their concrete experience that law was at best an illusion (appearance), and at worse violence (the long arm of the police). ${ }^{170}$

Thus perceived, the final spectacle in the last act could be interpreted as the defendants' sad 
concession that their efforts to put the government on trial (act as accusers), and thereby to prove the "justice of their cause", or that law was above politics came to a naught. They were conveying their realization that the trial could not give them a fair chance to present their side and the judge was not the neutral umpire they expected him to be. Instead, it was a show trial, a game, the outcome of which was predetermined. The end of the trial was already foreseen in the Seale spectacle. The "knife" appearing in the first act and reappearing in the third was violence perpetrated not by isolated incidents of police brutality, but by a systemic action under color of law. There is more to this scene.

Shoshana Felman theorizes that trials are re-enacted trauma. ${ }^{171}$ In her Forms of Judicial Blindness she shows how the O.J. Simpson trial echoed the universal trauma of battered women. The scene of the judicial robes may also be viewed as the re-enactment of trauma. First, the trauma of unfettered police power, brutalizing the protesters at the national convention in Chicago, after they were denied permit (probably unconstitutionally) to demonstrate. Later, the binding and gagging of Seale. In wearing the judicial robes and pointing to the intimate connection between judge and police, the defendants were offering the public another vision of law and order: law and order as cynical double talk, perverting rather than confirming fundamental justice and fairness.

The scene presents a caricature of law and order: the robe as law, the policeman's uniform as order. In the conventional understanding of the conception of law and order the two concepts are neatly separate while complementing each other. Law is presumably the senior partner (appearing first), embodying the properties of impartiality, predictability, and independence of politics. Order, the anti-thesis of chaos, is the result of adhering to the commands of the law. The experience captured by the Seale spectacle, of chaos generated by the deliberate and concerted action by judge and police, turned the concept of law and order on its head. At the end of the trial and outraged by their helplessness before "the law," Abbie and Jerry were saying that the entire trial was tainted by the corruption of this venerable concept. Their further act, of removing the robes, throwing them on the floor and treating them like rags (the Yiddish word schmate would best convey their message at this point), all in front of the silent judge, communicates this message vividly and powerfully.

Yet there is a twist here as well: it is the judicial robe, not the police uniform, which is treated so disrespectfully. This scene, then, conveys a further, dark and ominous message, that 
stripped to its essentials, society can do without the judge but not without the police. A more cynical message motivated by fear may also be read: at this point in the show (trial) the defendants could not afford to display a similar level of disrespect for the police. In the absence of consensus, respect is stirred not by legitimacy, but by fear.

There is a third way to interpret the scene: the glue of the noble marriage between law and order is an impartial judiciary. Once the judge fails to impress his impartiality on the audience, order must rest on the sheer superior might of the police.

The interpretation of the scene so far assigns its shocking value to the dark underground of the conception of law and order. But the richness of the scene lies precisely in its multiple meanings. There is more here than the concept of law and order. Some would be outraged by the humiliation to which the judge was subjected. Enough Americans at the time felt that the judge was abused by a group of anarchists, determined to drop America's most cherished institutions to the low level of a circus. Many felt that the judge was unjustly attacked. Others felt that even if he transgressed his boundaries and violated the code of judicial conduct, still the defendants (better yet, any defendants) should not have violated the ancient taboo on wearing judicial robes. The taboo is sacred. It symbolizes the law and thus guarantees the continuity of the system of justice.

What's in the robe? From the perspective of the trial as theater, the robes are another part of the costumes that make the mis-en-scène. The defendants were following the dress code of the 1960 's. ${ }^{172}$ The prosecution was adhering to the conventional style of the legal profession. The defense attorneys were sporting a compromise: longer hair but not too long, shaven faces; ties and jackets, no suits. The judge was clad in his black judicial robe. One thing Abbie and Jerry accomplished when they took off the robes was to remind the audience of the fact that underneath his gown the judge too, was wearing a different set of clothes and that this, too, may be significant. Underneath his robe, Judge Hoffman was wearing an expensive suit, made of the best cloth and by the best tailors. ${ }^{173}$ The gown equalized and democratized the judge. In his black robe he entered his role as a judge, no different from any other federal judges. Symbolically, one might say that his gown signaled his commitment to leave the value system of a particularly wealthy white male behind and to administer justice equally and fairly.

The ease with which Abbie and Jerry took off the robe may stand for the inverse message: the robe by itself cannot make the judge. Only the judge's conduct can defend the values for 
which the robe stands.

Why black? Color theory suggests that the traditional black color of the robe may signify the blindness of justice: just like the moon and the stars shine better against the dark sky, so will law (judicial-decision making) sparkle against the black cloth enveloping the person of the judge. ${ }^{174}$ Advertisers tell us that the color black stands for great wisdom. ${ }^{175}$ The color black also takes us to the sumptuary laws of the fifteenth and sixteenth centuries. It was the color of the upper classes and jealously guarded against imitation. ${ }^{176}$

The idea that a particular style (gown, robe) should be preserved for the governing elite goes back at least as far as Rome. Both Julius Caesar and Octavious prohibited ordinary citizens from wearing togas with purple edging worn by senators. ${ }^{177}$ It may well be that the taboo presently associated with wearing a judicial robe by anyone other than the judge is rooted in the sumptuary laws. Blasphemy laws may add explanatory power in this context. In the high middle ages, the law against blasphemy and the law against sedition were first degree cousins. Both frowned on deviations from the official line. ${ }^{178}$ The taboo on wearing the judicial robe is reminiscent of the prohibition on entering the holy of holies without Divine authorization. Something in wearing the judicial robe, in implying that anyone can do it, or the reverse - that it is an illusion, a hollow promise - is tantamount to undermining the integrity of the judiciary, and per se seditious. In light of the deep-seated yearning to believe that there could be a fair, honest and impartial process of dispute resolution, it is not surprising that American culture lives comfortably with the taboo on judicial robes.

Judicial robes stand for the idea that judges are the oracles of the law. Once the judge dons the robe $\mathrm{s} / \mathrm{he}$ is expected to neutralize any personal predilections and political preferences. ${ }^{179}$ Like any uniform, the robe makes the judge impersonal, almost interchangeable with other judges. The implication is that one judge would administer the trial and rule on matters of law in the same way that another judge would. The public interprets the donning of judicial robes as a ritual that signals impartiality. The person (tall, short, handsome, ugly, sickly, athletic, male, female, heterosexual, gay, democrat, republican) disappears. S/he is replaced by an abstract commitment to pre-set rules waiting to be implemented. There is also a dimension of high grandeur here, an allusion to the majestic quality of justice. The expectation is that judges will themselves assume a different mindset once they put on the robe. ${ }^{180}$

In his analysis of the sumptuary laws of medieval Europe, Alan Hunt challenges the 
conventional explanation of these laws as meant to discourage an imitation of the fashion of the elite. He suggests that the act of wearing the dress of the elite did not necessarily mean that the wearer was yearning to join the elite. The act may also be interpreted as a cry of outrage against the "authentic wearer", an attempt to challenge their monopoly, or better, to point to the discrepancy between the message of the dress and the substance of the behavior of the person entitled to wear the particular garments. ${ }^{181}$ Thus perceived, Abbie and Jerry were not trying to imitate or pretend to be judges themselves; rather, they came to remind the judge of his obligation towards them.

Support for this interpretation may be found in the expectation that "wearing someone else's uniform", as an act of outrage would contain a twist. Something in the garment would not conform. Indeed, Abbie and Jerry attached the yellow Jewish star to their robes as an act of protest.

Here is Judge Hoffman's description of the scene:

On February $6^{\text {th }}$, in the presence of the jury, the defendant Hoffman attempted to hold the court up to ridicule by entering the courtroom in judicial robes which he later removed, threw to the floor and used to wipe his feet. ${ }^{182}$

The police shirt and the yellow star are missing from this official description. ${ }^{183}$ Either Judge Hoffman wished the scene to be committed to memory as a mere act of imitation, without the associations of police uniform and yellow star, or he was so shocked by that spectacle, so overwhelmed by the affront to his person, that he failed to see the uniform or the yellow star. It is not clear which interpretation would form a more powerful comment on his character. As mentioned earlier, the contempt convictions were reversed on appeal and the case retried. ${ }^{184}$ In his trial for contempt, Abbie testified before Judge Gignoux:

Mr. Weinglass: And what, if anything, is missing in that particular description of the incident?

Abbie Hoffman: Well,... We had six-pointed yellow Jewish stars pinned to the robes, and when I took the judicial robe off, I was wearing a Chicago policeman's shirt underneath. ${ }^{185}$

Attorney Leonard Weinglass proceeded to inquire about the meaning of the spectacle:

Mr. Hoffman: Well, I had mentioned before about guerrilla theater, and I think that this was an example of guerrilla theater. There were no words spoken. We were saying that, in a symbolic sense, we were being persecuted, we were drawing attention to the fact that the Judge and Mr. Rubin and myself were of Jewish origins. We were trying to call 
attention to the fact that six million Jews had been exterminated in Nazi Germany, all with the blessing and assistance of the Court, all in effect legally sent away to the gas chambers. ${ }^{186}$

Indeed, towards the end of the trial, the defendants increasingly invoked the memory of Jewish persecution under Nazi rule. ${ }^{187}$ That, as Todd Gitlin has observed, was a general motif among the Jewish members of the New Left, and spread to their non-Jewish comrades as well. ${ }^{188}$ From the trial transcripts and from their writings it appears that Abbie and Jerry were obsessed with the Holocaust, the helplessness of the Jews during the Second World War, and the failure of the state (the law) to protect them. As Jews they must have identified deeply with the horror of being outlawed, stripped of rights and liberties, and thereby of humanity. They also felt rage at the version of Jewish history which they grew up to know: that Jews under Nazi occupation went like lamb to the slaughter and that the American Jewish Community failed to come to their brothers and sisters' rescue. ${ }^{189}$ They and their generation of young American Jews were now determined to correct that wrong through placing themselves on the firing line (instead of "going like lamb to the slaughter") and actively fighting against what they perceived to be an evil power. They were also angry with the judge, a fellow Jew who used his office to assist the oppressor (a repeat of the pattern of behavior of the Judenrat as described by Hannah Arendt? ${ }^{190}$ ) rather than deploy his judicial power to protect the oppressed.

The key to understanding the relationship between the yellow star and the policeman's shirt is the identity of "the oppressed." In the context of the late 1960s, and given the background of the defendants, most of whom were veterans of the civil rights movement, "the oppressed who failed to receive the protection of the laws" were not Jews but AfricanAmericans. The Seale spectacle repeated the mistreatment of blacks by courts and police. Abbie and Jerry, veterans of the Civil Rights Movement, identified strongly with the rage felt by blacks at the historic denial of their dignity. The act of pinning the yellow star to the black robe may be understood as a gesture to African Americans, a reminder of shared historical experiences. But the yellow star should not be understood as a mere expression of sympathy based on a similar past. Its meaning is more complex.

Until Bobby Seale was severed from the trial he enjoyed a tremendous influence over the strategic decision-making of the defense. For example, attorney Charles R. Garry was designated Chief Defense Counsel (over William Kunstler) out of deference to Seale, even though none of 
the seven defendants had had any previous experience with him. The yearning to show a black man, representative of the black power movement, that he is taken so seriously as to trump their own judgment and interests, was very powerful. It permeated the First Act of the Trial. Once Seale left the scene and race lost its dominant presence, Jewish discontent invaded the void that Seale had previously filled. The Jewish grievance was manifested in the many references to the Holocaust and Nazism, culminating in the judicial robes spectacle. The removal of the powerful need to display solidarity with Seale unlocked Jewish anger and frustration. The Jewish yellow star stood for the wound of $20^{\text {th }}$ Century Jews wherever they were, and Abbie and Jerry were demanding that the judge (and the Jewish prosecutor, Richard Schultz) take notice. ${ }^{191}$

The judicial robes scene, then, repeats the theme of the oppression of dissent (days before the official conviction), but also captures the complex relationship between law and society. In an immigration society such as the United States, the conception of justice is inextricably woven into the different narratives of the different ethnic groups. Not only is the master narrative based on the escape of the pilgrims from persecution, but the narrative of the trauma of slavery and the narrative of the Holocaust also make their appearance and claim. They furthermore interact with each other, both complementing and competing for expression and representation. Each defendant, each judge, carries within herself not only the master American narrative, but also their personal experience, based on their group affiliation and ethnic or racial origin. ${ }^{192}$

In Prometheus Bound, the chorus asks the shackled Prometheus what did he give humanity that so outraged Zeus:

Prometheus: I caused mortals to cease foreseeing doom Chorus: What cure did you provide them with against that sickness? Prometheus: I placed in them blind hopes. ${ }^{193}$

The defendants foresee doom. They no longer hold the blind hope that justice is blind. This is the terrifying recognition around which the trial revolves and which is so powerfully captured by this spectacle. And yet, one may argue that this is merely an experience on the trial level. In the American system of justice the conclusion is not reached until all the avenues of appeal and retrial are exhausted. From the perspective of trial as theater the show continues, this time before another audience -- that of the retrospective courts. 


\section{The Audience of Retrospective Judges: Appeal and New Trial}

All over the United States judges were watching the trial with fright and disbelief. Before their eyes, disorder in the American courtrooms was spreading uncontrollably. The minimal respect that used to be taken for granted was no longer there. It seemed as if the age-old restraints so painstakingly built over the centuries were coming apart. ${ }^{194}$ There was disagreement as to whether Judge Hoffman should be viewed as a brave hero fighting the barbarians or an accomplice, unwittingly fanning the flames of that wild fire. But no one could watch and remain calm.

The involvement of appellate judges in the trial started as soon as the trial began, when Judge Hoffman ordered the arrest of four defense attorneys of record who had no plans to continue work on the trial beyond the preparation of the preliminary motions. ${ }^{195}$ The Ping-Pong game between Judge Hoffman and the judges of the Seventh Circuit Court of Appeals during the trial is itself a chapter waiting to be written. For now, I shall skip this phase and review the judicial involvement in the aftermath of the trial.

In terms of the theatrical performance, there is nothing to commend the subsequent proceedings. The defendants behaved like ordinary appellants, the judges attended to the legal issues in the way that judges ordinarily do, and there were no spectacles and no sensation worthy of media attention. However, underneath the conventional façade of propriety, the judges were struggling with the events they have seen and grappling with their significance for the evolving notion of the rule of law. Their reaction, as an audience, therefore, is of primary importance for the lessons to be drawn from this drama.

A brief summary of the aftermath of the trial is necessary at this point. At the end of the trial, Judge Hoffman convicted all original eight defendants and their two lawyers of contempt of court and sentenced them to long prison terms. ${ }^{196}$ Five of the seven defendants were also convicted of individual charges of crossing state lines with intent to incite a riot. All were acquitted of charges of conspiracy. All appealed.

Seale's appeal was upheld by the Seventh Circuit, and a new trial was ordered. The government then decided to drop all charges, including the contempt convictions. ${ }^{197}$ In a separate appeal, the same panel of judges reversed all convictions of the defendants and their lawyers and remanded for a new trial. ${ }^{198}$ The government did not seek a new trial on the anti-riot charges, yet 
insisted on prosecuting the contempt charges so as "to vindicate the judicial process and deter other defendants and defense counsel from similar misbehavior." 199 In keeping with In re Seale's newly announced narrow definition of contempt of court, the government reduced the number of charges from 159 to 26. Judge Edward T. Gignoux acquitted the defendants of thirteen charges and convicted them of the other thirteen. The court of appeals affirmed. ${ }^{200}$

What did all of these courts have to say about the spectacles that made such a big part of the proceedings before Judge Hoffman? Let me begin with the binding and gagging scene and with the Supreme Court. ${ }^{201}$ As the reader may recall, Allen v. Illinois, a case decided by the Seventh Circuit Court of Appeals on July 7, 1969, was a precedential decision, permitting the binding and gagging of unruly defendants. It gave Judge Hoffman the idea that Seale could be bound and gagged and instilled in him the confidence that he was doing something appropriate and legal. ${ }^{202}$ By the time that Seale was bound and gagged, Allen v. Illinois was challenged before the Supreme Court of the United States. At the same time, the case of the Panther Twenty-One was pending before Federal District Court Judge John M. Murtagh in New York City. ${ }^{203}$

The Justices were watching both events. They saw what happened in Chicago. ${ }^{204}$ They also knew that Judge Murtagh needed guidance concerning the impending trial of the Panther Twenty-One. The disruptions of the Black Panther defendants during bail and pretrial hearings in New York City resulted in the indefinite postponement of the trial. As Judge Murtagh put it, he found a "simple formula," to deal with the disruptions in the courtroom: the defendants would stay in prison until they promise to behave in court. ${ }^{205}$ The "simple formula" also implied that Judge Murtagh (whom the defendants, in one of the rows in court, called Judge "Hoffman's brother-in-law") had learned his lesson from the Chicago Conspiracy Trial and was not willing to bind and gag "his" unruly defendants, despite the availability of precedent. The Supreme Court file in Allen v. Illinois shows that the justices were following the newspapers and understood well that they need to take a stand, quickly. On March 31, 1970 (almost six weeks after the end of the Conspiracy Trial in Chicago), the Supreme Court held that an unruly defendant may indeed be excluded from the courtroom. The Panther Twenty-One case was held later that year, without disruptions. ${ }^{206}$

In Allen v Illinois, the Supreme Court provided an alternative to binding and gagging. It allowed the removal of a defendant from the courtroom. But what did the Justices have to say about the practice itself, or about the spectacle of the bound and gagged Seale in the federal courthouse in Chicago? This 
in fact is one of the most interesting aspects of the inquiry into the relationship between law and theater. The audience watched and had time to form an opinion. What was it?

As expected, the answer is complex. The Seale incident was not mentioned in Allen v. Illinois, except in Justice Douglas' concurring opinion. ${ }^{207}$ The practice was condemned, but in spite of the strong language of condemnation - binding and gagging was not declared illegal. ${ }^{208}$ Speaking for the majority, Justice Black emphasized that "[E]ven to contemplate such a technique, much less see it, arouses a feeling that no person should be tried while shackled and gagged except as a last resort."209 Justice Black thereby conceded the power of trial as theater. "Seeing" the binding and gagging was a harrowing experience. Black listed "three inherent disadvantages" in the decision to bind and gag. It may affect the jury's feeling towards the defendants; it is a technique which amounts to "an affront to the very dignity and decorum of judicial proceedings that the judge is seeking to uphold"; and it obstructs defendants' abilities to communicate with their lawyers. ${ }^{210}$ He concluded: "However, in some situations which we need not attempt to foresee, binding and gagging might possibly be the fairest and most reasonable way to handle a defendant who acts as Allen did here.",211

The qualification built into this sentence, "in some situations that we need not attempt to foresee," may well give away the majority's judgment about the Seale incident. It may imply a deliberate judgment that Seale's binding and gagging could not be included in the roster of situations that would justify the technique. Concurring in the judgment Justice Brennan added: "In particular, shackling and gagging a defendant is surely the least acceptable of [the remedies available to a judge]. It offends not only judicial dignity and decorum, but also that respect for the individual which is the lifeblood of the law." ${ }^{212}$ The Supreme Court of the United States then, while distancing itself from the act in no uncertain words, could not bring itself to say plainly that such conduct did not fit an American judge.

Other courts, directly commenting on the Seale scene, similarly condemned the technique while stopping short of opining that it was unconstitutional. ${ }^{213}$ Judge Gignoux called the scene "the appalling spectacle", and held that during the binding and gagging "the trial proceedings had so disintegrated... that no judicial proceeding could fairly be said to be in progress." ${ }^{214}$ On this basis, he acquitted the defendants and their lawyers of all the contempt charges related to the scene. ${ }^{215}$

The Court of Appeals reviewing the defendants' convictions for contempt matter-of-factly stated that, "this was a measure deemed permissible." 216 At the same time, the Court held that Judge Hoffman erred when he failed to ask Seale why he insisted on Garry or why he did not wish to let Kunstler represent him. Thus the Court explicitly condemned Seale's "virtual 
gagging", but not his physical gagging. Moreover, on the level of "the virtual," the Court of Appeals condemned "binding" as applied to the defendants and recommended "the binding" of judges. The unanimous opinion referred to the "erroneous binding of Seale to Kunstler's representation" (emphasis mine). ${ }^{217}$ It further held that, "Since the trial judge was bound to look into the basis of Seale's dissatisfaction with his lawyers of record apart from the hospitalized Mr. Garry, failure to do so was an abuse of discretion" (emphasis mine). ${ }^{218}$ It was as if the Court was saying that in the courtroom "binding" is an abstract, not corporeal concept, and should apply first to those in charge of applying the law.

Thus, no court of law was prepared to directly confront Judge Hoffman's claim that he dealt with Seale "appropriately" and condemn the technique as illegal.

In his description of "the judicial robes spectacle", Judge Gignoux expanded the record to include the facts omitted by Judge Hoffman: that a Jewish yellow star was pinned to the robes and that Abbie was wearing a policeman's shirt underneath his robe. Judge Gignoux then convicted both Abbie and Jerry of contempt for staging the spectacle. He also decided that imposing a sentence would not be necessary. The Court of Appeals affirmed. ${ }^{219}$

About the criminal nature of the spectacle of wearing judicial robes to court, Judge Gignoux said:

Concededly, the record does not disclose that the conduct charged to these defendants ...caused any substantial disruption of the proceedings. However, as the Court of Appeals has stated, "the seriousness of the misbehavior bears on what conduct may be found materially obstructive." The conduct charged here was so flagrant, so outrageous and so subversive of both respect for the court and the integrity of the judicial process as to rise to the level of an actual and material obstruction of the administration of justice. The transcript further discloses that the conduct occasioned an entirely unnecessary and not insignificant delay in the proceedings. ${ }^{220}$

The central finding around which this paragraph revolved was the absence of any material disruption of the proceedings. Judge Gignoux forwarded primary and secondary reasons to justify conviction, regardless of the fact that actual disruption was not found. The primary reason was that wearing the robes was such "flagrant and outrageous" behavior as to "rise to the level" of an actual and material obstruction. Thus it appears that the district court was holding that the conduct was contumacious per se, independent of actual disruption, thereby invoking a similarity to the law of blasphemy. Judge Gignoux then threw in a secondary reason: "an unnecessary and 
not insignificant delay" in the proceedings. Nothing from the transcript was quoted to substantiate this claim.

Abbie and Jerry appealed and the Court of Appeals affirmed. However, its reasons revealed a disagreement with Judge Gignoux. The unanimous opinion read:

As the district court found... the transcript disclosed that this conduct occasioned an entirely unnecessary and not insignificant delay in the proceedings. The seriousness of this misbehavior supported the district court's conclusion that the conduct constituted an actual and material obstruction of the administration of justice. ${ }^{221}$

The Court of Appeals thus reversed the order of the reasons and omitted the leap from "outrageous behavior" to the conclusion that it "rose to the level of disruption.",22 The "finding of disruption" was left to coexist in tension with what I called the central finding of Judge Gignoux, that there was no actual disruption of the proceedings. At the end we are left with two courts and four judges who intuited that this was a criminal act, but who could not reach a consensus as to why that was so. ${ }^{223}$

It appears then, that subsequent courts called upon to review the spectacles were trying to split the injustice done by and in the Chicago Conspiracy Trial. The split is most visible in the result of Judge Gignoux's opinion: thirteen of the twenty-six charges resulted in acquittal and thirteen in conviction. Binding and gagging received a strong nod of disapproval, but its legality was not questioned nor its meaning probed. "From now on we shall not do it anymore" seemed to be a good enough judicial response to what happened, and "let us all forget it now" appeared to be the message. Wearing judicial robes to court by the defendants, on the other hand, was declared to be illegal, but punishment did not follow, as "the circumstances were special."224 Again, there was no effort to dwell on the meaning of the spectacle or its deeper and disturbing message about the theme of violence lurking underneath the banner of law and order.

A hint of the powerful drive to ignore meaning may be found in the following exchange before Judge Gignoux:

Abbie Hoffman: Well,... I think it interesting to note perhaps why the star and the Chicago policeman's shirt are missing. Perhaps that's the kind of reality that's too difficult for the Court to deal with at that time.

Mr. Starkman [prosecutor]: I will object to that and ask that it be stricken.

The Court: All right, the last - beginning "I think it is interesting?"

Mr. Starkman: Yes.

The Court: Will be stricken. ${ }^{225}$ 
Why is it that the courts circumnavigated the spectacles, refusing to declare the illegality of the first and only halfheartedly declaring the illegality of the second, carefully avoiding the painful messages contained in each, wrapping whatever insights they had in euphemistic language?

One way to explore the reason for this is to probe the reverse side of the famous aphorism that "justice must satisfy the appearance of justice." ${ }^{226}$ If justice must satisfy the appearance of justice," does it also follow that "injustice must satisfy the appearance of injustice", or that acts of injustice must come with an appearance of injustice?

In the robes scene, Abbie and Jerry were summing up the injustice inherent in "their trial," from the riots in Chicago to the binding and gagging to the abuse of judicial discretion immediately preceding the robes spectacle. Their appearance in judicial robes made injustice appear in all of its shocking ugliness. The Courts of retrospective judgment conceded that injustice was done, reversed, and ordered a new trial. But they could not accept the legality of such a stark "appearance of injustice" in the courtroom. Had Abbie and Jerry used words to express their ideas, while all other factors remained constant (same intent, same absence of actual disruption), it is probable that Judge Gignoux would not have found their behavior to be criminal. Why, then was it so difficult to hold that this spectacle, even if morally reprehensible, did not constitute a criminal offense? Such a result would have provided for symmetry between the approach to the Seale spectacle and the robes spectacle. The Courts of Appeals and on retrial did opine that the Seale spectacle was morally reprehensible, but refused to declare it illegal. Similarly here, the courts could have denounced the behavior as morally inappropriate while stopping short of outlawing it.

The key to understand this puzzle may well be found in the theory of the theater. In "The Theater and its Double," Antonin Artaud theorized that the theater's true function in the art world was to serve as "the double," as expositor of that hidden reality, which is at the bottom of the human experience:

The theater must also be considered as the Double, not of this direct, everyday reality of which it is gradually being reduced to a mere inert replica - as empty as it is sugar coated but of another archetypal and dangerous reality, a reality of which the Principles, like dolphins, once they had shown their heads, hurry to dive back into the obscurity of the deep. $^{227}$ 
Thus Artaud emphasized what became the cardinal insight of the theater of the avant-garde and what inspired creative stage directors since: the significance of the spectacle for revealing the "double," the unseen anarchic, demonic and scary underground of social reality. ${ }^{228}$ In another essay he referred to it as "the theater of cruelty." 229 Spectacle may instruct in a way that dialogue rarely succeeds. It can capture more authentically than any text the appearance of injustice, the malleability of law, the immense power of judges assisted by court marshals and prosecutors to distort justice.

Following Artaud, it may well be that the reasons why subsequent courts stepped around the spectacles, trying to avert their eyes from their deeper meaning, was precisely that these spectacles were too poignant, that they forced one into confronting the dark side of law and the capacity for injustice lurking in its bottom. ${ }^{230}$ The administration of justice proved that in the final analysis it relies on violence and that violence may sometimes be arbitrary and unjust. To call the wearing of robes legal would only expose a paradox, that the administration of justice is dependent on its capacity to do injustice. That, probably, was too much for the courts to concede.

It is inspiring to celebrate the appearance of justice, the American courts as "palladiums of liberty", as Justice Black refers to them in Allen v. Illinois, moments before he says that a judge may have to hold his nose and do the deed in extreme circumstances. ${ }^{231}$ It is disturbing to confront the appearance of injustice. This could be the reason why Judge Gignoux, in searching for an adequate way to end his opinion, chose a dialogue from a play. He may have been hoping that the poetry of theater will bring the yearned for catharsis. But before we get to Judge Gignoux's choice we need to acknowledge another powerful reason for the intuition of the subsequent courts that a circumspect approach to the spectacles was advised.

The Chicago Conspiracy Trial, present in every American home through television and newspapers, stirred very strong reactions in people. The country was divided: some insisted that Judge Hoffman was a true hero; others that he overstepped the boundaries of reason and fairness. It is safe to expect that the pendulum of public opinion tilted in favor of Judge Hoffman. It is certainly the case that powerful institutions of the establishment - another audience watching the trial -- placed themselves in Judge Hoffman's camp. President Nixon invited Judge Hoffman to a White House Breakfast, ${ }^{232}$ and the judge was selected as "Man of the Year" by the American Veterans of Foreign Wars. At the festive dinner where Judge Hoffman received his award, 
Senator Ralph Tyler Smith of Illinois spoke. Senator Robert Dole of Kansas made the speech a part of the Congressional Record. The Congressional Record shows both Smith and Dole denouncing the behavior of the Chicago defendants and praising Judge Hoffman. Senator Smith said:

Judge Julius Hoffman symbolizes to me - to all of us who honor him tonight - everything that is great and good about our system, and at the same time to expand and improve it for all mankind. He symbolizes the fact that law and order, in every definition of the phrase, is our first and best line of defense against the destroyers in our midst. ${ }^{233}$

The state of Florida, where Judge Hoffman took his vacations, ever devoted to law and order, passed a resolution stating that:

Whereas, the FLORIDA CABINET has observed the long trial in Chicago both with alarm the havoc brought on by the seven defendants and their attorneys and with pride for the calm demeanor in which Judge Hoffman faced this extreme challenge in behalf of legal decency;

NOW, THEREFORE BE IT RESOLVED that the Florida Cabinet does hereby go on record as representative of the citizens of Florida that we are in full support of Judge Hoffman's actions and we commend him for his forthright stand against the tyranny and disruption of this turbulent era;... ${ }^{234}$

A part of the dilemma of how to react to the Trial faced by the courts of appeals and by Judge Gignoux, then, was their realization that the country -- the larger audience watching this drama -- sought shelter behind the simple conventional slogan of law, order and civility, and was not willing to grapple with the ambiguous messages of the Trial. Maybe this was the reason why the subsequent courts declined the invitation to partake in a teach-in and preferred to uphold the need to stay behind one of their judges, even if they were not too happy about his conduct. This brings us back to Judge Gignoux.

At the end of his opinion, after explaining why, despite the convictions, no sentences should follow, Judge Gignoux searched for some rhetoric that will fit the "unique character and long history of this case." ${ }^{235}$ An Eisenhower appointee, he chose not the theme of law and order popularized by President Richard M. Nixon, but rather that of the rule of law, presumably a concept less willing to rely on the power of the police for survival. The moral he wished to convey was that "[t]rials which proceed in accordance with the law, the rules of evidence and the standards of demeanor not only reaffirm the integrity and viability of the judicial process, but also serve to insure the ability of each one of us to protect the rights and liberties we enjoy as 
citizens." ${ }^{236}$ He found it, as I already mentioned in the introduction to this paper, in Robert Bolts' play, "A Man For All Seasons."237

Judge Gignoux thus chose a piece of theater and a text that would be as far as possible from the spectacle and its message. He focused on the conventional, familiar and therefore calming insight about the rule of law, an insight that would bring the community together again: the devil will try to seduce us to compromise the sacred principle of the supremacy of the rule of law. We should resist the temptation, because at the end we ourselves will be denied the protection of the rule of law.

Viewed from the defendants' perspective the problem with this dialogue was not its familiarity but its blindness to their reality. Abbie and Jerry's spectacle sent the message that the defendants were not accorded the protection of the rule of law.

There is a remedy, Judge Gignoux could say: courts of appeals would, in due course, correct the wrong. The fact was that Judge Gignoux himself provided justice by refusing to attach prison sentences (violence) to the convictions. That explanation, however, is problematic for three reasons. It fails to address the reality of injustice in Judge Hoffman's courtroom; it ignores the fact that the binding and gagging spectacle was never declared illegal; and it poses a problem for the pristine message of the dialogue. If the rule of law may be recovered through the appellate process, then there is no permanent harm in sacrificing it to the devil on the trial level. The territory ceded to the devil may always be recaptured. The dialogue, however, implies that territory lost to the devil is permanently lost. ${ }^{238}$

The simplistic message of the dialogue, urging all participants to ignore their painful reality by means of remembering the noble dream, is further revealed when attention is paid to the role of the devil in human affairs. By staging two lawyers (humans) against the devil, the dialogue implies a confrontation between the forces of light and the forces of evil. It is easy to be led, on the basis of this dialogue, to impute demonic qualities to the other side and see oneself as the defender of civility. ${ }^{239}$ When one fights devils instead of other humans, the door is opened to irrational persecution and witch hunts, which is not far from the reality of this Trial. ${ }^{240}$

The most puzzling aspect of Gignoux's finale is the fact that the addressee is ambiguous. Whom is Judge Gignoux speaking to? Who does he think should profit from Bolt's dialogue? Is it the public at large? Judge Hoffman? The prosecutors? The defendants? Their attorneys? Does he mean to say that they all succumbed to the devil and violated the rule of law? The very 
ambiguity of the addressee may not qualify as good law, but does qualify as good theater. The audience is called upon to reflect on the question of who in fact was the greater violator of the rule of law in this drama. Not such a bad way to re-open the black box which contains the meaning of the Chicago Conspiracy Trial.

\section{Conclusion}

To paraphrase a cliché, rough theater makes bad law. The Chicago Conspiracy Trial was a travesty of justice. All of its participants in various ways and at different points in the trial subordinated the needs of law, justice and decorum to the temptation of spectacle. All share the blame. As a superficial matter, the very travesty of this trial disqualified it from entering the canon of jurisprudence. The case faded away, remembered only as a series of hilarious jokes traded between judge, various defendants, and their attorneys. But hard cases, even though they make bad law, populate legal casebooks. Why is it then, that the Chicago Conspiracy Trial has not been seriously studied?

The simple explanation is that cases on the trial level do not ordinarily enter the canon. This is a true enough but not satisfactory explanation. Some lower court cases do find their way into the canon. ${ }^{241}$ One does have to consider the presence of rough theater as a cause for the legal amnesia. In general, theater is not considered a medium in possession of explanatory powers of legal phenomenon. The literature does concede the resemblance between trial and theater, and yet legal scholars do not generally look to theories of the theater in their quest to explain legal culture. $^{242}$ It may well be that because of its association with "low" entertainment (circus), rough theater has failed to attract legal scholars. Can one search for enlightenment in the vulgar and the distasteful? I have tried to show that underneath this "circus" appearance of the trial there lay rich legal meaning waiting to be explored. The extraordinary, almost extravagant spectacles of the Chicago Conspiracy Trial contain serious insights into what law is and what it can accomplish, particularly during times of moral crisis.

The overarching theme of the trial was the perennial tension between order and chaos. From the government's perspective, the trial was about the need to rein in chaos and restore order. From the perspective of the defense, the trial was about exposing the harsh, bordering on the illegal, tactics of the government, and about the use of all means at their disposal to rally 
public opinion to protect them against the government's wrath. In other words, the defense claimed that the government mistook liberty for chaos. The spectacles presented at the trial, then, may be seen as an exploration, powerful, shocking, and sometimes revolting, of the tension between order and liberty. How the quest for order slides into brutal tyranny and how boundless liberty bursts the seams of civility.

So what? The skeptic will ask. You don't need a weatherman to know which way the wind blows. Law on the books is very different from law in action and law in action is violent? We've known that already. Besides, the subsequent courts corrected much of the injustice. We should remember Judge Gignoux as a model of judicial propriety and forget about Judge Hoffman, or think of him as merely a bad apple in the basket of judges. ${ }^{243}$ My analysis shows that the significance of this trial lies in the contradiction between these two "so whats." The very claim that the subsequent normative performance renders unnecessary the examination of the original wound rests on the implicit assumption that law in the books and law in action are one and the same. It reinforces the feeling that we are engaged in an effort to suppress the spectacle. This may be the moment to ask whether we have lost the capacity to be indignant, whether a commitment to civility demands the restoration of that capacity. ${ }^{244}$

Poet Antonin Artaud, the chief inspiration for the rough theater, opined that good theater is not merely about the replication of reality, but about the power to invoke archetypes and myths. This archetypal reality, emerging from the collective unconscious, he thought, is dangerous and frightful and for this reason resides in the dark depths of the unconscious. It only seldom makes an appearance, in the form of a spectacle, for a very brief while. ${ }^{245}$ The Chicago Conspiracy Trial, as I tried to show, contains scenes that possess these qualities. The scenes I analyzed invoked a long series of events, from universal and American culture, from the myth of Prometheus to slavery to sado masochism and torture. From Alice in Wonderland to the Roman crime of Lese Majeste to the sumptuary laws of the medieval period. For this very reason, it is appealing and frightening at the very same time. 
The theory of the rough theater, with its laughter, vulgarity, and terror captured the limits of justice in a way that, I would submit, is more powerful than learned text. The Chicago Conspiracy trial demonstrated the presence of violence in law, violence perpetrated by the discretionary power of judges, the human fragility of the persons administering justice (judge, prosecutor, jury), and the vulnerability of law itself. It showed that without basic consensus a trial cannot meet the conventional expectations and breaks down into a series of upsetting spectacles, spectacles which invoke the entire history of civilization. It may well be that this tragic insight into the impossibility of relying on law at the very moment that we wish to restore the rule of law is the reason why we prefer to forget the trial as nothing more than low entertainment. We may thereby condemn ourselves to repeat the spectacles once the threatening specter of chaos sweeps the land. 


\section{ENDNOTES}

1 The phrase comes from Abbie Hoffman's testimony before the court. The Conspiracy Trial, Judy Clavir and John Spitzer, 1970, p.366 (hereafter The Conspiracy Trial):

MR. WEINGLASS: Abbie Hoffman, prior to coming to Chicago, from April 1968 on to the week of the Convention, did you enter into an agreement with David Dellinger, John Froines, Tom Hayden, Jerry Rubin, Lee Weiner or Rennie Davis, to come to the city of Chicago for the purpose of encouraging and promoting violence during the Convention week?

THE WITNESS: An agreement?

MR. WEINGLASS: Yes.

THE WITNESS: We couldn't agree on lunch.

The protest groups that came to Chicago did not all have the same agenda. The National Mobilization Committee to End the War in Vietnam (MOBE), a loose coalition of anti-war groups, was openly political. Within MOBE, there was both strategic and tactical disagreement between David Dellinger, a well-known pacifist, and Tom Hayden and Rennie Davis, founders of Students for Democratic Society (SDS), who did not believe in pacifism as a guiding political principle. The Yippies (members of the Youth International Party) believed in cultural anarchy, and planned to hold in Chicago a "festival of life" in contrast to the Democratic "Convention of Death." The MOBE and Yippies did cooperate in bringing protesters to Chicago, but did not anticipate close cooperation once the convention started. The Black Panthers were not known to have an interest in either group. Black Panther chairman Bobby Seale was in Chicago for only one day and did not know any of the defendants except for Jerry Rubin. The two academics, John Froines and Lee Weiner, worked as MOBE ushers during the demonstrations, and were not known for holding leadership positions in the planning prior to convention week. The standard book on the events during the Chicago convention is David Farber's The Age of Great Dramas: American in the 1960s (New York, Hill and Wang, 1994). For the different positions of the defendants, see David J. Danelski, The Chicago Conspiracy Trial, in Theodor L. Becker, ed., Political Trials, 1971, p.134; Tom Hayden, Trial, 1970; David Dellinger, From Yale to Jail, The Life Story of a Moral Dissenter, 1993, p.330-331; Jason Epstein, The Great Conspiracy Trial, 1970, pp.94-95 [hereafter Epstein].

${ }^{2}$ Lahav, The Chicago Conspiracy Trial as a Jewish Morality Tale, in Sarat et al, Lives in the Law, University of Michigan Press 2002, 21-54.

${ }^{3}$ Throughout the trial the prosecutors tried to imply that the defendants and their friends were either homosexual or sexually promiscuous. Tom Foran, the senior prosecutor, did not try to disguise his homophobic attitude. A good example is his interrogation of poet Allen Ginsberg, who served as a witness for the defense. Foran asked Ginsberg to read poems explicitly referring to his homosexual fantasies, apparently in an effort to discredit him before the middle-class jury. There are several reports that at the end of Ginsberg's testimony, Foran muttered "Goddamned fag" as he returned to the prosecution table. E.g., Epstein, The Great Conspiracy Trial, supra n.1at p.320. Epstein further reports that a "week after the trial Tom Foran told a parents' meeting at Loyola High School in Chicago that the nation's children are being lost to a "freaking, fag revolution... the only one I don't think was a fag... was Bobby Seale." Id. at p.431. At least William Kunstler was stung by this "accusation" and felt the need to defend the defendants' "masculine honor." In an interview with Abbie Hoffman's biographer, Kunstler said: "right after the verdicts, Foran addressed a Holy Name Society where he referred to Abbie and Company as Fags. I had to laugh because they were fucking every woman in Chicago that would hold still long enough to be properly fucked. If anybody was not gay, it was the Chicago 8." Larry Sloman, Steal This Dream, p.218. Stories about the sexual promiscuity of the defendants were legion. Some were real and some based on fantasy and the rhetorical bravado of the defendants. See e.g., the cross-examination of defendant Abbie Hoffman in The Conspiracy Trial, p.368:

MR. SCHULTZ: At this meeting on the evening of August 7, you told Mr. Stahl that you were going to have nude-ins in your liberated zone, didn't you?

THE WITNESS: A nude-in? I don't believe I would use that phrase, no. I don't think it's very poetic, frankly.

I might have told him that ten thousand people were going to walk naked on the waters of Lake Michigan, something like that.

MR. SCHULTZ: You told him, did you not, Mr. Hoffman, that in your liberated zone, you would have-THE WITNESS: I'm not even sure what it is, a nude-in.

MR. SCHULTZ: --public fornication.

THE WITNESS: If it means ten thousand people, naked people, walking on Lake Michigan, yes. 
MR KUNSTLER: I object to this because Mr. Schultz is acting like a dirty old man.

MR. SCHULTZ: We are not going into dirty old men. If they are going to have nude-ins and public fornication, the City officials react to that, and I am establishing through this witness that that's what he did.

4 The monologue is delivered by Artie Sternlicht, a self-absorbed hippie leader (Abbie?), and is addressed to Daniel, Doctorow's fictionalized Rosenberg son:

Your folks didn't know shit. The way they handled themselves at their trial was pathetic. I mean they played it by their rules. The government's rules. You know what I mean? Instead of standing up and saying fuck you, do what you want, I can't get an honest trial anyway with you fuckers -- they made motions, they pleaded innocent, they spoke only when spoken to, they played the game. All right? The whole frame of reference brought them down because they acted like defendants at a trial. You dig?... I won't come on except as a judge of them, a new man, like a new nation with new laws of life. And they will be on trial, not me. You see? They blew the whole goddamn thing!

E.L. Doctorow, The Book of Daniel (New York: Penguin, 1971, 1996 ed.), p.151.

${ }^{5}$ The major books on the Trial are Jason Epstein, The Great Conspiracy Trial, supra n.1; John Shultz, Motion Will Be Denied, 1972 (hereafter Motion); Jules Feiffer, Verdict! The Exclusive Picture Story of the Trial of the Chicago 8 (a Third Press Book, 1970); Verna Sadock and Joseph Okpaku, Verdict! The Exclusive Picture Story of the Trial of the Chicago 8 (a Third Press Book, 1970); Anthony Lukas, The Barnyard Epithets and Other Obscenities, 1970; and Contempt, Transcript of the Contempt Citations Sentences, and Responses of the Chicago Conspiracy 10, 1970 (contains a foreword by Attorney General Ramsey Clark, and an introduction by Professor Harry Kalven, Jr.) Excerpts from the Trial transcript were published in The Conspiracy Trial, supra n.1, and the appellate briefs were published in A. Kinoy, H.E. Schwartz \& D. Peterson, eds., Conspiracy on Appeal (Center for Constitutional Rights, 1971). The editors represented the defendants on appeal. An excellent analysis of the trial is provided by David J. Danelski, supra n.1. This list does not include biographies or memoirs.

${ }^{6}$ The diggers were anarchist actors, active in the San Fransisco area in the mid- to late-1960s, who tried to use the theater in order to educate people about politics. Todd Gitlin reports that, "To protest an execution at San Quentin, they butchered a horse." See Todd Gitlin, The Sixties, Years of Hope, Days of Rage, Bantam Books, revised edition 1993, p.223. They perfected the idea of guerrilla theater ("American MPs simulated beating German POWs to death in the middle of Berkeley's Sproul Plaza, with no announcement that this was Theater." Id.) The diggers had considerable influence on Abbie Hoffman who was impressed by their determination "to manipulate the media." See Jonah Raskin, For the Hell of It, The life and Times of Abbie Hoffman, University of California Press: 1996, p. 100 .

${ }^{7}$ The concept of guerrilla theater rested on a theatrical improvisation where the fact that a piece of theater is being staged is not announced in advance and dawns on the spectators as they are watching. See id. In his contempt trial for wearing judicial robes to court, Abbie Hoffman explained: "'I think that this was an example of guerrilla theater. There were no words spoken. We were saying that, in a symbolic sense, we were being persecuted." In the Matter of David T. Dellinger, 370 F. Supp. 1304, 1973. Direct examination of Abbie Hoffman, Trial Transcripts (hereafter TR.), p.2838. See also, Judith Malina and Julian Beck (founders of The Living Theatre), Paradise Now, The Rite of Guerrilla Theater, Random House (1971), p.15.

${ }^{8}$ In his memoirs, Making Scenes [hereafter Brustein], Robert Brustein identifies the two founders of The Living Theater, Judith Malina and Julian Beck, as the first to stage "revolution as theatre" in their 1964 trial for failure to pay income tax." Judith Malina, wearing a long judicial gown she called her "Portia costume," conducted her own defense, examining a number of witnesses." Brustein next describes the apex of The Living Theater visit to New Haven, where, in a production of Paradise Now, the actors "abandoned any effort to create artistic imitation" and invited the spectators [Yale undergraduates, PL] to "leave the theatre and convert the police to anarchism." Brustein describes "the most frightening moment of the entire week" as follows: "People were massed up and down the street waiting to be let in; firemen were posted at every door; police were waiting for the first sign of disturbance; and the Living Theater, inside the building, was beginning to shout, "The theatre belongs to the People." The waiting crowd outside picked up the chant, "The theatre belongs to the People." A few of those within were trying to open the doors. The policemen holding them outside tensed; the mood was turning ugly; anything could have sparked a full-fledged riot. Suddenly the doors on the side of the theatre burst open, and three burly men in porkpie hats ran in, shouting, "The theatre belongs to the people..." They were campus police. Having gained entrance, they barred the doors and stood in front of them with their arms folded. The crowd quieted down; the actors went on with the show; and the riot was averted." R. Brustein, Making Scenes, A personal History of the Turbulent years at Yale 
1966-1979, 1981, pp. 65,69, respectively. The latter description is a wonderful example of how the use of benign theatrical techniques by the government averted violence. On The Living Theater see: John Tytell, The Living Theater (New York: Grove Press, 1995); The Living Book of the Living Theatre, with an introductory essay by Richard Schechner, Connecticut: New York Graphic Society Ltd. (1971); Julian Beck, The Life of the Theatre, San Francisco: City Light Books, 1972. Lawrence Friedman, Lexitainment .

${ }^{9}$ Compared to the voluminous bibliography on law and literature, there has been little effort at theorizing the meaning of theater in the courtroom. For specific attempts to analyze particular playrights, see: Milner S. Ball, The Promise of American law, The University of Georgia Press, 1981, particularly chapter 4; Robert P. Burns, A Theory of the Trial, Princeton U. Press, 1999, 132-41; Julie Peters, Theatrical Orators, Spectacular Colonialism,

Testimonial Catharsis: Richard Brinsley Sheridan and the Trial of Warren Hastings, unpublished; Michael Freeman, "Truth and Justice in Bertolt Brecht", 11 Cardozo Stud. L. \& Literature 197 (1999). For discussion of the performance of trial lawyers during trials as "storytelling", see Dana K. Cole, Psychodrama and the Training of Trial lawyers: Finding the Story" 21 N.Ill.U. L.Rev. 1 (2001), and David Ball, Theater Tips and Strategies for Jury Trials (2d ed., 1997) (advice for the improvement of lawyers' performance during trial).

${ }^{10}$ TR. at pp.172-3. Description of reactions of participants by John Schultz, Motion Will be Denied (William Morrow \& Co.: New York, 1972) (hereinafter Schultz, Motion) 3, 32: Judge Hoffman "exploited every possibility for melodramatic emphasis and rhythm and cast a spell with his voice upon the attention of hundreds of people with the reading of what was otherwise a long and boring document. With aghast fascination, I watched and heard him build the sentence that "John R. Froines and Lee Weiner, defendants herein, did teach and demonstrate to other persons the use, application and making of an incendiary device - "With crescendo fervor, he let the tight vowels and sibilants burst from him. "Following Kunstler's interruption Judge Hoffman abandoned his dramatic style of reading. Id. at p.33. Shultz also reported that, "A former prospective juror had said on television that she could not have been fair and impartial after hearing the judge's expressive performance." John Shultz, "The Substance of the Crime Was State of Mind" - How A Mainstream, Middle Class Jury Came to War With Itself, 68 UMKC Law Review 637, 642.

${ }^{11}$ The Federal Anti-Riot Act of 1968, 18 U.S.C.A. $\$ \S 2102,2109$ (1968). The indictment can be found in Conspiracy Trial, supra n.1 at p.601. The eight defendants were: David Dellinger, chairman of the national MOBE, Rennie Davis and Tom Hayden, of the MOBE, and also leaders in the SDS, John Froines, Lee Weiner (academics), Abbie Hoffman and Jerry Rubin leaders of the Yippie movement, and Bobby Seale, Chairman of the Black Panther Party for Self-Defense. The Anti-Riot Act was passed in April, 1968 and this was the first time it was invoked. The Act was sustained by the Seventh Circuit with the dissenting opinion of Judge Pell. Dellinger v. United States, 410 U.S. 970, 93 S.Ct. 1443 (1973).

${ }^{12}$ From the beginning, Seale insisted that Charles R. Garry, the attorney who defended the Black Panthers in California, represent him at the trial. The other defendants accepted his preference and appointed Garry chief defense counsel. See Seale; Kunstler. Infra at n.000. William M. Kunstler with Sheila Isenberg, My Life as a Radical Lawyer, Citadel Press (1996), p.17.

13 October, 15,1969

MR. KUNSTLER: Your Honor, just one preliminary application this morning. The defendants who were not permitted by your Honor to be absent today or to have a court recess for the Vietnam moratorium brought in an American flag and an NLF Flag which they placed on the counsel table to commemorate the dead Americans and the dead Vietnamese in this long and brutal war that has been going on.

The marshal removed those from the table. First he took the NLF Flag after directing me to order the client to have it removed which I refused to do, and then he removed it himself, and then subsequently he removed the American flag.

THE COURT: We have an American flag in the corner. Haven't you seen it during the three-and-a-half weeks you have been here?

MR. KUNSTLER: Yes, but we wanted the juxtaposition, your Honor, of the two flags together in one place.

THE COURT: Mr. Kunstler, let me interrupt you to say that whatever decoration there is in the courtroom will be furnished by the Government and I think things look all right in this courtroom. The Conspiracy Trial, pp.92-93.

${ }_{14}^{14}$ The Conspiracy Trial, p.519.

15 Id. at 530-532. On the next day, when the motion to challenge the order to terminate bail is argued and rejected, Abbie hoffman makes the statement: "Your idea of justice is the only obscenity in the room. You schtunk. Vo Den? 
Schande vor de goyim, huh?" [You skunk, what more? A shame before the Gentiles.] Id. at 533. Dellinger spent the remaining days of the trial in custody. D. Dellinger, from Yale to Jail, The Life Story of a Moral dissenter (New York: Pantheon Books, 1993) 360.

${ }^{16}$ In Re Dellinger.

17 Schultz, Motion, supra n.1 at p.348.

${ }^{18}$ U.S. v. Dellinger, 472 F.2d 340 (1972). There was a dissenting opinion by Judge Pell challenging the constitutionality of the Anti-Riot Act on first amendment grounds, but all three judges agreed that the convictions should be reversed and ordered a new trial.

19 For a review of the extensive acts of lawlessness in the highest rungs of government, see, e.g., Theodore H. White, Breach of faith, The Fall of Richard Nixon, Atheneum Publishers, 1975; Leon Jaworski, The Right and the Power, The Prosecution of Watergate, Reader's Digest Press, 1976; Stanley I. Kutler, Abuse of Power, The New Nixon Tapes, The Free Press, 1997.

20 Interview with Professor Thomas J. Campbell, Stanford Law School, May 10, 2001. Professor Campbell, son of Chief Judge William Campbell of the Chicago Federal District Court, recalled that the refusal of the district court judges to preside over the new trial was based on solidarity with Judge Hoffman.

${ }^{21}$ See infra at n.000.

${ }^{22}$ At the end of the trial, five defendants were found guilty, and two, Lee Weiner and John Froines, were found not guilty. However, Judge Hoffman convicted all defendants, including Weiner and Froines, of contempt of court. After the reversal and remand by the Court of Appeals, the government did not press the contempt convictions of Weiner and Froines. In the contempt trial before Judge Gignoux, therefore, stood five defendants -- Dellinger, Davis, Hayden, Abbie Hoffman, and Rubin -- and two attorneys -- Kunstler and Weinglass. Judge Gignoux found Dellinger, Abbie Hoffman, Rubin, and Kunstler guilty, and Davis, Hayden, and Weinglass not guilty. In the Matter of David T. Dellinger, supra n.000 at pp.19-20. In the Matter of David T. Dellinger et al, 370 F.Supp. 1304, 13221323. Decided on Dec. 6, 1973.

${ }^{23}$ For an insightful analysis of trials as an event, see Robert P. Burns, A Theory of the Trial, Princeton, 1999.

${ }^{24}$ Consider Peter Brook's observation that, "The actor himself is hardly ever scarred by his efforts. Any actor in his dressing room after playing a tremendous, horrifying role is relaxed and glowing. It is as though the passage of strong feelings through someone engaged in strong physical activity is very healthy." Peter Brook, The Empty Space (Touchstone: New York, 1968, 1996 ed.), p.136 [hereafter Brook]. In fairness to Brook, it should be added that he also emphasizes that actors pay a price for their performances: "But I also think that there is a price. The material you use to create these imaginary people... is your own flesh and blood." Id.

${ }^{25}$ See defendant David Dellinger's description of his time in Cook County jail after Judge Hoffman revoked his bail on Feb. 4, 1970: "[h]e was 'led through a series of way stations. Everywhere you stand and wait... And then you wait another twenty minutes or a half hour. At last you're taken to the pump room, which is so jammed with humanity that after I'd been there ten minutes I looked around to see if anybody was suffocating. And then you move from there to the next station. Every time you leave, you're stripped. Your anus is examined. 'Lift your right foot. Lift your left foot. Spread your cheeks. Turn around. Jump up and down. Stick your tongue out.'"' Quoted in Jason Epstein, The Great Conspiracy Trial (New York: Random House, 1970), p.401. Five of the convicted defendants spent fifteen days in jail before the Court of Appeals reversed the denial of bail. Epstein, supra n. 000 at 430 .

${ }^{26}$ Robert Cover, Violence and the Word, 95 Yale L. J. 1601, 1606 (1986).

${ }^{27}$ See e.g., ABA-AIA Joint Committee On The Design of Courtrooms And Court Facilities, The American Courthouse: Planning and Design For The Judicial Process (1973); Allan Greenberg, Courthouse Design: A Handbook for Judges and Court Administrators, ABA Commission on Standards of Judicial Administration (1975); J.S. Wolfe, Toward a Unified Theory of Courtroom Design Criteria: The Effect of Courtroom Design on Adversarial Interaction. Wolfe criticizes models for courtroom design for overemphasizing lighting, acoustics, and sightliness, while paying little attention to the adversarial function of the space. See also, Katherine Fischer Taylor, In the Theater of Criminal Justice: Official Architecture and Its Representations (Princeton University Press, 1993, p.9). But see observation that the courtroom is designed to distance the audience from the actual performance of the legal matters transpired before the court, thereby mystifying the process: "the closest analogy [of the courtroom in the English speaking world, PL]... is to the medieval cathedrals of Europe, where the worshippers were separated from the nave, the scene of all the action, by an ornate but largely opaque carved screen. The cathedrals were designed so that the ordinary folk heard lovely sounds emanating from behind the screen - in an ancient and indecipherable language - but they were not permitted access to the mysteries occurring out of sight." Thomas W. 
Church, The Mansion vs. the Gatehouse: Viewing the courts from a consumer's perspective, 75 Judicature, 255, 258 (1992).

${ }^{28}$ For an interesting sample, see M. Belknap, American Political Trials, Greenwood Press, 1981.

${ }^{29}$ Erich Good and Nachman Ben-Yehuda, Moral Panics, The Social Construction of Deviance (Blackwell, 1994), p.31: "The moral panic... is characterized by the feeling, held by a substantial number of the members of a given society, that evildoers pose a threat to the society and to the moral order as a consequence of their behavior and, therefore 'something should be done' about them and their behavior. A major focus on the 'something' typically entails strengthening the social control apparatus of the society -- tougher or renewed rules, more intense public hostility and condemnation, more laws, longer sentences, more police, more arrests, and more prison cells." For a wonderful case study of the concept, see Orit Kamir, Every Breath You Take: Stalking Narratives and the Law 5-12 (U. of Mich. Press, 2001).

${ }^{30}$ I borrow the notion of an archetypal trial from Northrop Frye's analysis of literature: "The symbol... is the communicable unit, to which I give the name archetype: that is a typical or recurring image. I mean by an archetype a symbol which connects one poem with another and thereby helps to integrate and unify our literary experience." In a similar fashion, one may conceive of archetypal trials as providing the communicable unit, a symbol which connects one trial to another and thereby helps to integrate and unify the legal experience. Northrop Frye, Anatomy of Criticism, Four Essays, 1958, p.99.

31 See, e.g., attorney William Kunstler closing arguments for the defendants:

MR. KUNSTLER: Before I come to my final conclusion, I want to thank you both for myself, for Mr. Weinglass, and for our clients for your attention. It has been an ordeal for you, I know. We are sorry that it had to be so. But we are grateful that you have listened. We know you will weigh, free of any prejudice on any level, because if you didn't, then the jury system would be destroyed and would have no meaning whatsoever. We are living in extremely troubled times, as Mr. Weinglass pointed out. An intolerable war abroad has divided and dismayed us all. Racism at home and poverty at home are both causes of despair and discouragement. In a so-called affluent society, we have people starving and people who can't even begin to approximate the decent life.

These are rough problems, terrible problems, and as has been said by everybody in this country, they are so enormous that they staggger [sic] the imagination. But they don't go away by destroying their critics. They don't vanish by sending men to jail. They never did and they never will.

To use these problems by attempting to destroy those who protest against them is probably the most indecent thing that we can do. You can crucify a Jesus, you can poison a Socrates, you can hang John Brown or Nathan Hale, you can kill a Ché Guevara, you can jail a Eugene Debs or a Bobby Seale. You can assassinate John Kennedy or a Martin Luther King, but the problems remain. The solutions are essentially made by continuing and perpetuating with every breath you have the right of men to think, the right of men to speak boldly and unafraid, the right to be masters of their souls, the right to live free and to die free. The hangman's rope never solved a single problem except that of one man.

I think if this case does nothing else, perhaps it will bring into focus that again we are in that moment of history when a courtroom becomes the proving ground of whether we do live free and whether we do die free. You are in that position now. Suddenly all importance has shifted to you--shifted to you as I guess in the last analysis it should go, and it is really your responsibility, I think, to see that men remain able to think, to speak boldly and unafraid, to be masters of their souls, and to live and die free. And perhaps if you do what is right, perhaps Allen Ginsberg will never have to write again as he did in "Howl," "I saw the best minds of my generation destroyed by madness," perhaps Judy Collins will never have to stand in any courtroom again and say as she did, "When will they ever learn? When will they ever learn?"

The Conspiracy Trial, supra n.000 at p.567.In the contempt trial which followed the reversal by the court of appeals, David Dellinger, representing himself, said to judge Gignoux:

MR. DELLINGER: As I look at my notes there is one legal case which I should have cited. If I may be permitted to do so.

THE COURT: Of course you may.

MR. DELLINGER: By the way, Mr. Foran kept referring to 200 years of Anglo-Saxon justice.

This was in the Colonial times, an early precedent but it was the case of Peter Zangler [sic] who was tried for seditious remarks and was already proved to have made the remarks. The jury declared him not guilty because they considered him to be in line with the conscious of the community.... 
MR. KUNSTLER: Your Honor, although that is not reported, there is a transcript of the 1735 trial ....and I

will attempt to get that transcript to you if your Honor would like to read it.

THE COURT: It won't be necessary. I am quite familiar with Zangler [sic]. ...

TR., Filed Jan. 30, 1974, 73-2107, pp.525-6, In the Matter of David Dellinger, 461 F.2d 389 (1973).

32 Bernard Schwartz, A History of the Supreme Court, Oxford University Press, 1993, at pp.57-8. The conviction of the leaders of the American Communist Party was confirmed in Dennis v. United States, 341 U.S. 494 (1951); the trial judge's performance during the trial was discussed by the Supreme Court in Sacher v. U.S., 343 U.S. 1 (1952). See also Hawthorne Daniel, Judge Medina, Wilfred Fund, Inc., NY, 1952 at pp.235-83, and Michael R. Belknap, Cold War Political Justice: The Smith Act, the Communist Party and American Civil Liberties, Greenwood Press, 1977.

33 Thus for example, the singing of Country Joe in the courtroom, as well as the singing of Judy Collins and Pete Seeger, were gratuitous and encouraged a vaudeville atmosphere in the courtroom, widening the gap between the judge and the defendants and those respective parts in American public opinion which supported each side. (One side, fearful that chaos and anarchy is spreading into the country's most venerable institutions; the other side buoyed by its ability to destabilize courtroom decorum and entrenched in its conviction that it is misunderstood.) On the other hand, the decision of the prosecution to have poet Allen Ginsberg read his wet dream poem to the jury also resulted in a spectacle (Ginsberg was a gifted reader, especially of his own poems), and was equally gratuitous, aimed at associating the defendants with the "unseemly" behavior of homosexuality and playing on the middleclass's homophobia.

${ }^{34}$ Supra n.24.

35 Brook directed theater groups in Stratford-Upon-Avon, London, New York, and Paris. One of his most memorable productions was King Lear, which he also turned into a film. His opera productions included The Marriage of Figaro and Faust.

${ }^{36}$ Brook, p.42.

${ }^{37}$ Brook, p. 10.

${ }^{38}$ Brook: "Even if the theatre had in its origins rituals that made the invisible incarnate, we must not forget that apart from certain Oriental theaters these rituals have been either lost or remain in seedy decay." P.45.

39 Brook, pp.48-9.

${ }^{40}$ Antonin Artaud, The Theater and Its Double, Mary Caroline Richards, trans. (1958), p.48 [hereafter Artaud].

${ }^{41}$ Brook, p.72.

${ }^{42}$ Brook, p.73.

${ }^{43}$ The term "the theatre of cruelty" was coined by Artaud, supra n. 000 at p.89. By theater of cruelty Artaud meant not the depiction of cruelty for cruelty's sake, but rather a theater that will capture raw human existence with all its pain and conflict: "If the theater, like dreams, us bloody and inhuman... it is in order to perpetuate in a concrete and immediate way the metaphysical ideas of certain Fables whose very atrocity and energy suffice to show their origin and continuity in essential principles." Id. at p.93. As an example Artaud offers "The Fall of Jerusalem: according to the Bible and history; with the blood-red color that trickles from it and the people's feeling of abandon and panic visible even in the light; and on the other hand the metaphysical disputes of the prophets, the frightful intellectual agitation they create and the repercussions of which physically affect the King, the Temple, the People, and events themselves." Id. at p.99. See also Chapters from the History of Stage Cruelty, Gunter Ahrends and Hans-Jurgen Diller, eds. (Tubinger: Narr, 1994).

${ }^{44}$ Robert S. Brustein, one of the most influential drama critics in America, was dean of the Yale School of Drama, and director of the Yale Repertory Theatre Company, 1966-1979, and director and artistic director of the American Repertory Theater. James Reston, Jr., described him as "the Protean master of all aspects of stagecraft, from acting to directing to producing to criticism and scholarship." Contemporary Authors Online, The Gale Group (2001). Jan Kott, a Polish American theater critic and expert on Shakespeare, was described as "one of the handful of theater critics who have changed the perception of masterpieces." Jan Kott, New York Times, January 4, 2002 p. A22. 45 Brustein, supra n.000, at p. 29.

46 Jan Kott, Shakespeare Our Contemporary (W.W. Norton: New York, 1974), Boleslaw Taborski, transl., p.348. ${ }^{47}$ Brustein believed "in a synthesis between the past and the future - between tradition and experiment, between text and performance technique.” R. Brustein, Making Scenes, Random House, 1971 at p.27. But Brustein felt traumatized by the events at Yale in 1968-1969 and later sharpened his belief in the separation of the theater from politics. R. Brustein, Reimagining American Theatre, Hill and Wang, 1991, 280. 
${ }^{48}$ As Brustein put it, the idea was to "provide a much more satisfactory example of classical interpretation,..." Brustein, supra n.000 at p.31. The Lowell adaptation "contained references to the Vietnam War and the Johnson administration." Id. at p.23; and "Prometheus... emerged less a savage titan, raging against his fate, than a bitter self-hating young man, scornful of himself and of the gods, often reluctant even to give the heavens the benefit of his indignation.. The result of all this was a thoroughly modernized version of the ancient play, with contemporary resonances echoing all forms of tyranny (including America's treatment of the Vietnamese), but a version that nevertheless maintained a certain historical distance." Id. at pp.34-5. Jonathan Miller, already recognized as a maverick director with exciting ideas, set the play in a "decaying seventeenth-century culture that has gone bad. The characters are prisoners, they put on the play in this eternal imprisonment as a punishment." Id. at p. 32.

49 Robert Brustein, Making Scenes, A Personal History of the Turbulent Years at Yale, 1966-1979 (New York: Random House, 1981) 23. Brustein also says that a grant from the National Endowment for the Humanities to produce the play was almost canceled because "President Johnson, enraged to discover that a government agency had awarded money to someone he believed had insulted him, demanded that the award be withdrawn... this represented the first attempt by government to politicize the decisions of the agency.” Id. at 31.

${ }^{50}$ Brustein, p.51.

${ }^{51}$ Brustein, p.51.

52 Jules Feiffer, supra n.000; Feiffer also took Abbie Hoffman to have lunch at the exclusive Chicago Standard Club, where Judge Hoffman and other federal judges dined daily. Id. at p.131.

${ }^{53}$ Supra text accompanying notes.

54 Brook, n.000 at p.68. For an exposition of the carnavalesque as a form of low culture, which at the same time functions as a challenge to high culture, see Mikhail Bakhtin, Rabelais and his World, Indiana University Press, 1984 (Hélène Iswolsky, trans.).

${ }^{55}$ Supra, n. 10.

${ }^{56}$ See supra, n.000.

${ }^{57}$ Robert Bolt, A Man For All Seasons, Vintage Books, 1960.

${ }^{58}$ In the Matter of David T. Dellinger, supra n.000 at p.1323. The dialogue between Sir Thomas More and William Roper, his son-in-law, takes place towards Act I of A Man For All Seasons. Sir Thomas has just had a visit from the King, and his family is concerned about the escalating tensions between the King and his Lord Chancellor. William Roper is present when Richard Rich, who will eventually collaborate in bringing about Sir Thomas' demise, drops in for a visit. All members of More's family distrust Rich. Roper urges More to recognize Rich for the spy that he is and arrest him. More refuses, replying, "and go he should, if he was the devil himself, until he broke the law!", at which point Roper retorts, "So you should give the devil the benefit of the law", and gets More's famous response. By comparison to the Seale scene, this is a tame and anemic dialogue which does not bear immediate consequences. Robert Bolt, A Man For All Seasons, Vintage Books, 1960, at pp.62-7.

${ }^{59}$ For those willing to exercise their imagination, the dialogue presents the metaphor of a forest, contrasted with barren land where "there is no place to hide." The metaphor of the "good" forest may profitably be contrasted with the "bad" jungle in Chief Justice Warren Burger's imagination of the forest in his dissenting opinion. Burger's opinion concerned the doctrine of 'fighting words' in the first amendment context, Rosenfeld v. New Jersey, 408 U.S. 901, 902 (1972): "When we undermine the general belief that the law will give protection against fighting words and profane and abusive language such as the utterances involved in these cases, we take steps to return to the law of the jungle."

${ }^{60}$ The dialogue does raise the theme of the Faustian Bargain, and from this perspective echoes an important element of moral philosophy and culture.

${ }^{61}$ Bush v. Gore, 531 U.S. 1060 (2000). Alan M. Dershowitz writes: "He [Justice Scalia, PL] peeked beneath the blindfold of justice and decided the case not on neutral principles or precedents designed to govern future cases, but rather on the basis of whom he wanted to see win this election," Alan M. Dershowitz, Supreme Injustice, Oxford University Press (2001), p.132. Judge Richard A. Posner writes: "On one side was a preference for order - for an orderly transition, an orderly succession, an avoidance of protracted partisan wrangling, of an awkward interregnum, and of a diminished Presidency. On the other side was a preference for a more populist, perhaps even carnivalesque, but certainly less orderly and legalistic conception of American democracy." Richard A. Posner, Breaking the Deadlock, Princeton University Press (2001), p.256.

${ }^{62}$ Artaud, supra n.000 at p.81.

${ }^{63}$ Many would agree that law as applied does frequently fail to meet the lofty criteria set for it. It is also important to remember that not all believe that "a law for all seasons" is a good thing. See, e.g., eminent political scientist 
Robert G. McCloskey: "Neither Marshall nor his predecessors nor his successors have, until lately at any rate, displayed much diffidence about substituting their judgment for that of others when the moment for doing so seemed auspicious. But they have displayed a fairly consistent awareness that for everything on earth there is a season." [Emphasis mine, PL] Robert G. McCloskey, The American Supreme Court, Revised by Sanford Levinson, $3^{\text {rd }}$ Edition, 2000, p.74.

${ }^{64}$ Historians may disagree with the impression that More did not contribute his share to manipulating the law for the benefit of the King during his tenure as Lord Chancellor. See e.g., Peter Ackroyd, The Life of Thomas More, Nan A. Talese, 1998. Furthermore, from the perspective of the history and philosophy of law, Bolt's story of More suggests a contradiction: what undermined More was his failure to violate the law. Had he hid Roper's admonition and agreed to arrest Richard Rich he might have been able to avert his downfall. At the same time, More's trial and execution are portrayed by Bolt as lawless, thus proving that "the law" was not there for him when he needed it. Thus, the implication of Bolt's narrative is the opposite of the one More espouses explicitly: Because More refused to violate the law, it was not there to protect them. For insightful analyses of the paradox resulting from the need "to violate the law in order to uphold it", see Robert C. Post, On the Popular Image of the Lawyer, Reflections in a Dark Glass, 75 Cal L. Rev. 379, 380 (1987), and William H. Simon, Moral Pluck: Legal Ethics in Popular Culture, 101 Colum. L. Rev. 421 (2001). I am grateful to William H. Simon for clarifying these points to me.

${ }^{65}$ Northrop Frye, Anatomy of Criticism, Four Essays (1957), p.282.

${ }^{66}$ For Peter Brook, Brecht's idea of a dialogue was "the opposite of the happening": "alienation is to shock us into bringing the best of our reason into play... Alienation can work through antithesis; parody, imitation, criticism, the whole range of rhetoric is open to it." Brook, supra n.000 at pp.72-3. ... See also, Henry Goodman, Bertolt Brecht: Dualism and Tradition, in Rosario P. Armato and John M. Spalek, Medieval Epic to the "Epic Theater" of Brecht, Essays in Comparative Literature, University of Southern California Press, 1968, at p.219: "His [Brecht's] ability to turn a familiar concept inside out, to stand on end a habitual value and see it as something unfamiliar, produced his famous Alienation Effect. The shock of contradiction could, at least in theory, free his audiences from their normal trance and waken their critical responses. As an example: a prostitute... falls romantically in love with a man who uses her devotion to exploit her. The commonplace foolishness of the situation stems from the fact that a 'love professional' is the victim; and it is rendered even more absurd when we realize that she is the only idealist in the entire play. Brecht makes us look at idealism. Might it possible be abusive? But, can we really afford to live without it?"

${ }^{67}$ Supra p. , n.000-000.

${ }^{68}$ During convention week in Chicago, Reverend Abernathy himself was engaged in a highly theatrical public spectacle. In behalf of the Southern Christian Leadership Council and the Poor People Campaign, he led a threewagon mule train through the streets of Chicago. While the defendants did not get permit to demonstrate, the muletrain was authorized to march, thereby attracting many of the protesters on the streets. See David Farber, Chicago '68, The University of Chicago Press (1988), p.199.

69 "Mr. Kunstler: ... I am going to go back on my representation anyway with one more witness, your Honor. We had originally contacted Rev. Ralph Abernathy to be a witness for the defense in this case. Dr. Abernathy was then out of the country and has just returned and is willing to appear as a witness for the defense. He is arriving at this moment at O'Hare Airport. Also, Mr. Abernathy made a speech at Grant Park directly related to the events of the night of Wednesday, August 28. I did not know that he would be back in the country when I spoke to your Honor on Friday afternoon. His testimony is not long and it would be the last witness we would offer subject only to those records." The Conspiracy Trial, p.518.

${ }^{70}$ Of course there are differences between the two examples. The Bolt-Gingoux dialogue is an excerpt in a judicial opinion. The Abernathy incident takes place in a real court and the conditions of the courtroom themselves infuse the scene with power. But the Bolt-Gignoux dialogue was also read, as a part of the Gignoux opinion, in a packed and tense court.

${ }^{71}$ In the same scene the judge also expresses his frustration at the abuse of the law of evidence by the defense: "The Court: There have been several witnesses called here during this trial whose testimony the Court ruled could not even be presented to the jury - singers, performers, and former office holders. I think in the light of the representations made by you unequivocally, sir, with no reference to Dr. Abernathy, I will deny your motion ..." Id. at p.518.

72 After commenting that the "quasi-public position that the "justice" of the mob should supplant the ordered process of the courts is no longer prevalent." Robert Cover cited an article by Charles Bonaparte, published in the Yale Law Journal in 1899, titled "Lynch Law and its Remedy." Calling the article extraordinary, Cover summarized 
the article as "arguing that underlying purpose of lynching is "not to violate, but to vindicate, the law; or, to speak more accurately, ... its 'adjective' part... is disregarded that its 'substantiative' [sic] part may be preserved." Cover, Violence and the Word, 95 Yale L. J. 1601 (1986), 1624, n.58, quoting from 8 Yale L. J. 335, 336 (1899).

${ }^{73}$ Brook, p.68.

74 “--Mr. Davis: I applauded too, your Honor. Throw me out.-- The Court: Unfortunately, you have to remain., Mr. Davis., but we note that you applauded. You say you applauded." Id. at p.519. Defendant Rennie Davis is expressing his own contempt for the court by daring the judge to exclude him while calling him "your Honor" thus making a mockery out of the age-old respectful manner of addressing a judge. The judge admits that he is powerless to exclude Davis from the courtroom.

${ }^{75}$ Note also the double appearance of the word "out". Kunstler accuses the judge: "You are saying truth will not out." A few second later Judge Hoffman orders, "Out with the applauders." Id. at p.519. Kunstler uses the word in its positive sense, bringing the truth "in." Judge Hoffman deploys the negative sense - excluding certain spectators from the courtroom.

76 "'No,no!” said the Queen. 'Sentence first - verdict afterwards.'

'Stuff and nonsense!' said Alice loudly. 'The idea of having the sentence first!'

'Hold your tongue!' said the Queen, turning purple.

'I won't!' said Alice.

'Off with her head!' the Queen shouted at the top of her voice. Nobody moved."

Lewis Carroll, Alice's Adventures in Wonderland, http://www-2.cs.cmu.edu/People/rgs/alice-XII.html

${ }^{77}$ For his diatribe, Kunstler was convicted by Judtge Gignoux of contempt of court in his retrial. No sentence was imposed. In re Dellinger, 730 F.Supp. at 1323.

78 The Seventh Circuit Court of Appeals refers to ample notice being given to the trial court of Seale's choice of counsel through continuance motions, pretrial proceedings, Seale's pro se motion dismissing all counsel for him in Garry's absence, and Seale's attempt to make a pro se opening statement to the jury. U.S. v. Seale, 461 F.2d 345, 358 (7th Cir. 1972).

${ }^{79}$ During the contempt retrial the Court rejected the "sabotage theory." In a footnote, Judge Edward T. Gignoux, who presided over the second contempt trial of the defendants, said: "The theory of the government's case was, in substantial part, that the defendants came to the Anti-Riot Act trial intent upon its destruction. Counsel argues that the sentences here imposed should reflect this particular culpable design. .. This Court, however, is unable to find that the evidence establishes beyond a reasonably doubt the existence of any such plan" In the Matter of David T. Dellinger et al, 357 F.Supp. 949 (1973), 1321, n.22.

${ }^{80}$ On October 20, 1969, Bobby Seale brought a motion to release him on bail so that he may do the preparatory legal work in representing himself. "Mr. Schultz: May I briefly reply, your Honor? Your Honor, this is a ploy. It's just a simple, obvious ploy. The ploy is so obvious... The Court: ..." The right to discharge one's counsel and appear pro se is not unqualified if an accused seeks to exert it after trial has commenced. I find now that to allow the defendant Seale to act as his own attorney would produce a disruptive effect. Moreover, the denial of the defendant's motion to appear pro se would not be prejudicial to his case. On the contrary, the complexity of the case makes self-representation inappropriate and the defendant would be more prejudiced were he allowed to conduct his own defense than if his motion were to be denied. Mr. Clerk, the motion of the defendant Bobby Seale to appear pro se will be denied as will his motion for release on bail." The Conspiracy Trial, p.114. The Court of Appeals opined that Judge Hoffman never bothered to engage Seale in a dialogue in order to learn from him directly why he was so insistent on Garry.

${ }^{81}$ This was made explicitly clear by the court of appeals, Seale, 461 F.2d at pp.356-61.

${ }^{82}$ The prosecution was aware of the discussions between Seale and his attorney as it was constantly (and illegally) monitored by the FBI. The Court of Appeals ordered this information to be shared with Seale, which is one of the reasons why the government eventually decided not to pursue a new trial. Id. at 366.

${ }^{83}$ The Conspiracy Trial, supra n.000 at p.118:

October 22, $1969 \ldots$

MR. SEALE: Can I speak on that and answer his argument?

THE COURT: No. This is not your motion, sir. Your motion has been decided.

MR. SEALE: In other words, I can't speak in behalf of myself?

THE COURT: Not at this time, sir.

MR. SEALE: Why not?

THE COURT: Because this is your lawyer's motion. 
MR. SEALE: That ain't my lawyer. ...
\[ * * * \]

October $27,1969 \ldots$

THE COURT: I don't know what you are going to say and you have a very competent lawyer of record here.

MR. SEALE: He is not my lawyer and you know I fired him before that jury was even picked and put together.

THE COURT: Will you ask him to sit down, Mr. Marshal? ...

... MR. Kunstler: I might say, your honor, you know that I have tried to withdraw from this and you know that Mr. Seale---

THE COURT: I don't know what you tried to do. I know your appearance is of record, and I know I have your assurance orally of record that you represent this man.

MR. KUNSTLER: Your Honor, you can't go on those semantics. This man wants to defend himself.

THE COURT: This isn't semantics. I am not fooled by all of this business. ...

${ }^{84}$ U.S. v. Seale, 461 F.2d 345, 373.

${ }^{85}$ This was against the dissenting opinion of Chief Judge Hastings. In the Aeneid, Virgil recounts how the prophet Glaukon warned the Trojans: "Beware of gift giving Greeks." Still, they rushed outside the city's gates to get the wooden horse. Beware of radical steps applied to radical situations, warned Judge Hastings of the Court of Appeals in his dissenting opinion in Allen v. Illinois. Judge Hoffman only saw a legal horse ready to be mounted.

${ }^{86}$ [William] Allen v. Illinois, 413 F.2d 232 (1969), p.235: "we are of the view that the defendant should not have been excluded from the courtroom during his trial despite his disruptive and disrespectful conduct. The proper course for the trial judge was to have restrained the defendant by whatever means necessary, even if those means included his being shackled and gagged." See also Lahav, The Chicago Conspiracy Trial: Character and Judicial Discretion, 71 U. of Colorado L. Rev. 1327 (2000).

${ }^{87}$ Id. at

${ }^{88}$ Telephone interview with William E. Gardner, Judge Hoffman's stepson, July 9, 1998.

${ }^{89}$ In describing his appearance in court, Jerry Rubin wrote: "Since color TV is where it's at, I used to wear bright colors every day to court: red pants, green pants, yellow polo shirt with red lines, multicolored headband, incredible tie-dye shirts." Jerry Rubin, We Are Everywhere, Harper and Row (1971), at p.29.

${ }^{90}$ Shultz, p.68.

91 "That fall - with many young people waiting half the night outside the Federal Building to get a seat - the judge was in particular demand from hostesses eager for a pass to the jammed courtroom." Anthony Lukas, The Barnyard Epithet and Other Obscenities, Notes on the Chicago Conspiracy Trial, Harper and Row (1970), at p.46. Lukas also reports that Judge Hoffman's guests told him that the judge called the marshals and asked them to seat his guests in the press section; and that while sanctioning a refusal to allow Bobby Seale's wife into the courtroom the judge said, "I leave seating at the courtroom completely to the marshals." Id. at p.48.

${ }^{92}$ David Dellinger, the oldest of the defendants (and the one consistently to wear a tie and jacket to court), was fiftyfour years old. Abbie Hoffman and Bobby Seale were thirty-three years old. Jerry Rubin was thirty-one years old. Lee Weiner and John Froines were thirty years old. Only Tom Hayden and Rennie Davis were twenty-nine years old, and thus below thirty. Information based on Biography and Genealogy Master Index, Gale Group Databases.

${ }^{93}$ The Conspiracy Trial, supra n.1 at pp.148-9.

${ }_{94}$ Cover, supra, p.1603, n.5, quoting Victor Navasky, Naming Names (1980), p.346.

95 Cover, id., n.5.

96 "Mr. Seale: That man is not my lawyer. The man made statements against me. Furthermore you are violating

Title 42, United States Criminal Code. You are violating it because it states that a black man cannot be

discriminated against in his legal defense. It is an old Reconstruction law and you won't recognize it, so I would like to cross-examine the witness.

The Marshal: Sit down, Mr. Seale.

Mr. Seale: Hey did you see me make a speech in Lincoln Park, William--Mr. William Frapolly? Did you see me make a speech in Lincoln Park?

The Court: Mr. Marshal, will you ask that man to be quiet.

And, Mr. Seale--

Mr. Seale: Did you see me make a speech in Lincoln Park supposedly on August 27, Tuesday--supposedly on August 27, Tuesday? 
The Court: Let the record show that the defendant Seale keeps on talking without the approval of the Court and in spite of the admonition of the Court and in contempt of the Court.

Mr. Seale: Do you know a Robert Pierson? A lying agent?

The Court: You needn't answer any of those questions. Let the record show that the defendant--

Mr. Seale: Let the record show you violated that and a black man cannot be discriminated against in relation to his legal defense and that is exactly what you have done. You know you have. Let the record show that.

The Court: The record shows exactly to the contrary.

Mr. Seale: The record shows that you are violating, that you violated my constitutional rights. I want to cross-examine the witness. I want to cross-examine the witness.

The Court: I admonish you, sir, that you have a lot of contemptuous conduct against you.

Mr. Seale: I admonish you. You are in contempt of people's constitutional rights. You are in contempt of the constitutional rights of the mass of the people of the United States. You are the one in contempt of people's constitutional rights. ..." The Conspiracy Trial, pp.152-3.

${ }^{97}$ Id. at p.153. The court of appeals, while reversing and remanding the contempt convictions of the defendants, commented on the legal significance of the refusal to rise: "such symbolic acts, when not coupled with further disturbance or disruption, sometimes might not rise to the level of an actual and material obstruction of the judicial process... some of the failures to rise here could be found nonobstructive." In re Dellinger, supra n.000 at p.401.

98 The judge and prosecutors fear the Black Panthers - which is why they felt that maximum security was needed in the room. The defendants are threatened by the judge that their bail might be revoked. Their attorneys are equally threatened with contempt of court.

99 TR. 4641, In re Dellinger, 461 F.2d 345, 382. .

100 TR. 4752. [check also Shultz, Epstein]

101 Jason Epstein, The Great Conspiracy Trial, (New York: Random House, 1970), p.254.

102 MR. SEALE [gagged]: Give me your assurance that you will let me defend myself.

THE COURT: I can't understand you, sir.

MR. SEALE [gagged]: I want to defend myself. I have a right to speak in behalf of my constitutional

rights, and you just violated my constitutional rights to speak on behalf of my constitutional rights.

...

THE COURT: Did you want to say something, sir?

MR. KUNSTLER: I wanted to say the record should indicate that Mr. Seale is seated on a metal chair, each hand handcuffed to the leg of the chair on both the riight and left sides so he cannot raise his hands, and a gag is tightly pressed into his mouth and tied at the rear, and that when he attempts to speak, a muffled sound comes out. MR. SEALE [gagged]: You don't represent me. Sit down, Kunstler.

THE COURT: Mr. Marshal, I don't think you have accomplished your purpose by that kind of a contrivance. We will have to take another recess.

Let the record show again the defendants have not risen.

The Conspiracy Trial, p.163.

${ }^{103}$ Id. at p.255.

104370 F.Supp. 304 (1973), 1310.

105 Id. at p.1311.

${ }^{106}$ In re Dellinger.

107 Infra at $p$.

${ }^{108}$ In interview with Professor Thomas J. Campbell, supra n.20, I learned that Judge Hoffman did consider a glass booth for the defendants, but decided against it as he did not wish to draw attention to any similarity between this trial and the Eichmann trial. The idea of a glass booth was also considered by the American Bar Association in 1970, as the legal profession became concerned with disruptions in the courtroom. Herman Schwartz, Judges as Tyrants, 7 Criminal Law Bulletin 129: "committees of lawyers and judges have been considering such things as Eichmann-type glass booths for disruptive defendants."

${ }^{109}$ Brook, supra n.000 at p.66: "The Rough Theatre... is usually distinguished by the absence of what is called style. Style needs leisure: putting over something in rough conditions is like a revolution, for anything that comes to hand can be turned into a weapon. The Rough Theatre doesn't pick and choose: if the audience is restive then it is obviously more important to holler at the trouble makers - or improvise a gag - than to try to preserve the unity of style of the scene." 
${ }^{110}$ See also Judge Gignoux: "The evidence does not establish beyond a reasonable doubt that the conduct charged to these defendants in these specifications was the cause of the breakdown of the proceedings [during the Seale spectacle, PL] or occasioned an actual and material obstruction of the administration of justice." In re Dellinger, supra n.000 at p.1311.

${ }_{111}$ A "beat them by joining them" tactic, showing that no one, not even old-fashioned conservative judges were immune to the allure of spectacle in the late 1960s.

${ }^{112}$ The website http://www.queernet.org/deviant extols the pleasures of binding (and gagging?). "The thrill of bondage may be in the appearance and sensation of being restricted or tied, and for many the sense of helplessness and the consequent symbolic lack of responsibility on the part of the bound person for what happens to them is often very important... knowing you cannot escape whatever's happening to you may help you relax into the scene and enjoy it." The website proceeds to distinguish between, on the one hand, bondage and discipline, and sadomasochism on the other: "Bondage can be made both firm and comfortable and for some this may be enough without additional discomfort or pain -- which is why 'Bondage and Discipline' (B\&D) is sometimes distinguished from SM."

${ }^{113}$ Such as, for example, in the binding and gagging episode in Woody Allen's film Bananas. But it appears that Allen was guided by political correctness, and rather than binding and gagging an African-American, defendants preferred a white Jewish leftie. Allen also permitted his bound and gagged character to represent himself in court (i.e., interrogate witnesses), a point which added to the absurdity of the situation.

${ }^{114}$ Alexander Hamilton understood this well: "liberty can have nothing to fear from the judiciary alone, but would have every thing to fear from its union with either of the other departments." The Federalist 78,

http://memory.loc.gov/const/fed/fed 78. html p. 2. Hamilton hoped that life tenure for the judiciary would immunize judges from collaboration with the executive branch. The Seale incident is proof that such immunity is fragile, as judges do rely on the powers of the executive (the police) to execute measures not always conforming to the values underlying the rule of law.

${ }_{115}$ Michel Foucault, Discipline and Punish, p.12.

116 Id. at p.13.

117 The Conspiracy Trial, p.163. Watching the defiant, bound and gagged Seale also makes one contemplate the question of whether there are any sufficiently effective means to force a determined person into compliance. Would any more extreme measures fit into our notion of the rule of law? It may well be that only through watching this scene did Judge Hoffman and the audience begin to understand the notion of binding and gagging, which until then was abstract and therefore, perhaps, acceptable to some. But see below, reaction of subsequent courts.

118 Section 33 of the international Standard Minimum Rules for the Treatment of Prisoners provides: Instruments of restraint, such as handcuffs, chains, irons and strait-jacket, shall never be applied as a punishment. Furthermore, chains or irons shall not be used as restraints. Other instruments of restraint shall not be used except in the following circumstances:

(a) As a precaution against escape during a transfer, provided that they shall be removed when the prisoner appears before a judicial or administrative authority; (b) On medical grounds by direction of the medical officer; (c) By order of the director, if other methods of control fail, in order to prevent a prisoner from injuring himself or others or from damaging property; in such instances the director shall at once consult the medical officer and report to the higher administrative authority.

34. The patterns and manner of use of instruments of restraint shall be decided by the central prison administration. Such instruments must no be applied for any longer time than is strictly necessary. Approved by the Economic and Social Council by its resolution 663 C (XXIV) of 31 July 1957 and 2076 (LXII) of 13 May 1977. www.unhchr.ch/html/menu3/b/h_comp34.htm The language of Section 33 seems to imply the illegality of the techniques used to restrain Seale.

119 Invoking the theater of the absurd, one is reminded again of the Queen of Hearts' statement that, "Sentence first - verdict afterwards." Supra n.76.

120 "They had four large, thick belts which were bolted with special key-and-lock attachments at the buckles. My legs were both strapped tightly by Goliath [Seale's nickname for one of the marshals, PL]. Nummy, another marshal, was securing my wrists and forearms to the chair, as another one, Arizona, who was wearing doctor's rubber gloves, gagged me. Arizona then took a stretch-type cloth bandage wrapping and wound it around and around my head, over my mouth, the back of my neck, my ears, and under my chin; it gripped my vocal cords like a vice... My breath was short and faint, and I couldn't even gesture to tell these bastards. ...I could feel the loss of blood circulation in my hands... As I wiggled my head, the stretch wrapping got tighter and tighter - my whole face 
felt trapped. ...Slim and Goliath picked up the chair, carrying me into the courtroom. I had lost all blood circulation in my left hand and both legs... the wrapping around my head was killing me. Fear was suddenly with me as I began to imagine that I might pass out and die before anyone even noticed... Marie [member of the defense team, PL] got a pencil and put it between my fingers and put a pad under my strapped-down right hand. I tried to write but dropped the pencil. She picked it back up, placed it between my numbed fingers, and sort of guided it to help me spell straggly words, so I could tell someone.” A Lonely Rage, The Autobiography of Bobby Seale, Times Books, 1978, at pp.194-5. Seale also reports that throughout the trial he was held in the prison's hospital, being treated with large doses of medication for a sever case of VD. Id. at p.186. In addition, he was being treated for tonsillitis and was "worried about his throat." Epstein, supra n.1 at p.263. Avishai Margalit's discussion of the requirement of a decent society (at minimum, avoidance of humiliation) is very instructive here, A. Margalit, The Decent Society, Harvard U. Press, 1996, particularly pp.262-70.

${ }^{121}$ Judge Hoffman's reference to the binding and gagging as "unusual and extraordinary things" appears in The Conspiracy Trial, supra n.1 at 169. In Seale's certificate of contempt Judge Hoffman stated, "His continued disruptive conduct made it necessary... for the first time in the experience of this Court to physically and forcibly restraint him." U.S. v. Seale, p.374.

${ }^{122}$ U.S. v. Seale, supra n.000 at p.__. "Indeed, in the instant case the uniform three-month sentence for each specified act of contempt could leave the impression that no special attempt was made to make the penalty proportionate to the offense for which it was imposed."

${ }^{123}$ John Schultz described the scene in Motion Will Be Denied, supra n.000 at pp.64-5:

The next day many young Black Panthers were jammed into the audience. There were also more marshals. The black marshals tended to be in their early forties, with close-cropped hair, and the Black Panthers in their twenties with large round naturals. Behind the custody door, before the proceedings began, the marshals asked Seale, in the name of the judge and for themselves, if he would caution the Panthers.

"Brothers and sisters," Seale said, and went on to tell the young Panthers that self-defense was the principle of the party and if a marshal attacked them they should defend themselves, but otherwise, Seale said clearly, they should keep cool, listen, and if a marshal should ask "us to leave, we leave." He used the first-person plural in a strong, affectionate way.

The judge entered, the defendants did not rise, and the judge noted them for the record. Kunstler made a motion protesting Conspiracy staff members being searched, and Weinglass counted the marshals in the courtroom for the record, about twenty.

Richard Schultz interrupted the judge, who had called twice for the jury, "If the court please, if the court please." Then Schultz said that Seale had spoken to the audience about an "attack by them." Schultz twisted the word "attack" into three utterly distorted descriptions of what Seale had said, implying that Seale had urged the audience to attack the court. Laughter came from spectators and press. "You're lying!" Seale screamed. "Dirty liar! I told them to defend themselves. You are a rotten fascist pig, fascist liar, that's what you are!"

The spectators shouted, "Right on!"

Judge Hoffman said that if the laughter occurred again, he would direct the marshals to clear the courtroom. "Let the record show," he said, "the tone of Mr. Seale's voice was one of shrieking and pounding on the table and shouting."

Schultz apologized and attempted to retract his characterization of what Seale had said. "I'm sure your honor will understand." But it was lost in the furor of the judge's indignation.

${ }^{124}$ Crime of lese majeste or injured majesty. Cite Otto Kirchheimer, Political Trials

125 Images from the trial were communicated through the sketches of reporters who were sitting in the press row. Schultz, supra n.000 at p.

${ }^{126}$ The racist aspect of the trial should be understood in the context of deepening racial tensions in America of the late 1960's. The Anti-Riot Law (upon which defendants were prosecuted) was itself passed after a wave of race riots in many American cities. The assassination of Martin Luther King, Jr., the rise of the black power movement and the FBI persecution of the Black Panthers were all symptoms of the times, invoked in the vivid image of the bound and gagged Seale in the Federal courtroom in Chicago.

${ }^{127}$ Seale understood his unique position very well and tried to exploit it. For example, during the binding and gagging, he made it clear to the remaining seven defendants that he preferred that they would not attempt to protest his condition in a way that would take the public attention away from him and his condition. See e.g., Dave Dellinger, More Power Than We Know, Anchor Press, 1975 at p.250; Abbie Hoffman, Soon to be a Major Motion Picture, Perigee Books, 1980, at p.195: "This was Seale's show though." 
${ }^{128}$ For a comparison between Prometheus and Chris see Carl Grabo, Prometheus Unbound, An Interpretation (Chapel Hill: The University of North Carolina Press, 1935) at 38. In the literature, there is disagreement about whether Jesus was bound or nailed, see Haim Cohn, The Trial and Death of Jesus, Harper \& Row, N.Y. 1967, 1971, p. 219 .

${ }^{129}$ The generational tension was astutely captured in the exchange between Judge Hoffman and Seale:

The Court: We are going to recess now, young man. If you keep this up -

Mr. Seale: Look, old man, if you keep up denying me my constitutional rights... “

U.S. v. Seale, 461 F.2d 345, 383.

130 This is not the place to discuss the multi meanings of fire in human consciousness. Fires in the inner cities of America (precisely what the authors of the Anti-Riot Act feared) were the most shocking spectacle in the year 1968. In free speech jurisprudence, fear of chaos or revolution is translated into fear of fire. See e.g., Justice Oliver Wendell Holmes in Schenck v. United States, 249 U.S. 47, 52 (1919):

The most stringent protection of free speech would not protect a man in falsely shouting fire in a theatre and causing a panic.

and Justice Sanford in Gitlow v. People of the State of New York, 268 U.S. 652, 669 (1925):

A single revolutionary spark may kindle a fire that, smouldering for a time, may burst into a sweeping and destructive conflagration. It cannot be said that the State is acting arbitrarily or unreasonably when in the exercise of its judgment as to the measures necessary to protect the public peace and safety, it seeks to extinguish the spark without waiting until it has enkindled the flame or blazed into the conflagration.

131 In re Seale, p.380 (461 F.2d 345). TR., pp.4342-6.

${ }_{132}$ Larry Sloman, Steal This Dream, Doubleday, 1998, p.195.

133 Id. at p.197.

134 Id.

135 This movement is itself significant for the understanding of law, because it signifies the narrow evidentiary ground upon which a final legal decision is being made. The jury knows less than other participants in the trial, and this fact is emphasized by the fact that they are periodically banned from the courtroom, where the "censored" information is heard.

136 The Conspiracy Trial, p.164.

137 He continued to use the euphemism long after the trial. See e.g., his exchange with Tom Hayden at the end of the trial. Hayden points out to Judge Hoffman that the marshals regretted their treatment of Seale. The judge responds: "I deeply regret and I certainly waited a long time before I did what the law permitted me to do and had to do in order to quiet him... there is no human being who would like to take the steps that we had to take in order to quiet Mr. Seale." [Emphasis added.] Contempt, Transcript of Contempt Citations, The Swallow Press, Chicago, 1970, p. 101. See also supra n.000. For the use of euphemisms, see George Orwell, Politics and the English Language, The Collected Essays of George Orwell, vol.IV, p.127.

138 Shultz, Motion, p.66.

${ }^{139}$ Jan Kott and Peter Brook on the value of Pantomime in theater. A painting of Christ during the crucifixion?

140 U.S. v. Seale, 461 F.2d 345, p.385. The different manners of speech are themselves a part of the courtroom theater. The judge speaks high English and is careful to exclude "low" references. He also views critically the vernacular used by Seale, see e.g., his reaction to the term "motherfucker".

${ }_{141}$ Prometheus Bound, supra n.000 at p.313.

142 THE COURT: Have him sit down, Mr. Marshal.

MR. SEALE: I want my constitutional rights. I want to have my constitutional rights. How come you won't recognize it? How come you won't recognize my constitutional rights? I want to have the right to crossexamine that witness.

MR. SCHULTZ: May the record show, if the Court please, that while the marshals were seating Bobby Seale, pushing him in the chair, the defendant Dellinger physically attempted to interfere with the marshals by pushing them out of the way.

${ }^{143}$ Id. In his memoirs David Dellinger described the scene: "My chair was next to Bobby's and the previous time that the marshals had "seated him," I had seen one of them knee him in the testicles and had heard Bobby's involuntary gasp of pain. So this time, as the marshals were "seating" him, I got between Bobby and them and I was the one who got kneed in the balls, not having been smart enough to protect myself in the manner I had learned 
from SNCC in the South.” David Dellinger, From Yale to Jail, The Life Story of a Moral Dissenter (Pantheon Books, New York: 1993), pp.350-1.

${ }^{144}$ Jason Esptein, The Great Conspiracy Trial, supra n.1 at p.260: "Meanwhile, Rubin had turned in his own chair to help Seale. 'This guy,' he cried, 'is putting his elbow into Bobby's mouth and it wasn't necessary at all...' Seale meanwhile had managed to pull his gag off. 'Don't hit me in the balls,' he shouted at the marshals, who continued to struggle with him."

145 "Rennie Davis: That was really the most intense time of the trial. You'd actually see blood coming out of the mouth of Bobby, because they had spent two hours trying to push gauze, against his resistance, into his mouth before wrapping his mouth and head. And the shackles were so tight, he was losing his circulation in his arms." Steal this Dream, supra n.000 at p.196.

${ }^{146}$ Bobby Seale, A Lonely Rage, The Autobiography of Bobby Seale, Times Books: New York, 1978), pp.194-6. ${ }^{147}$ U.S. v. Seale, supra n.000 at p.386:

"The Court: The court will be in recess for a few minutes.

The Marshal: This court will take a brief recess."

148 Cover, Violence and the Word, p.1615.

149 "Your Honor," Weinglass asked, "Mr. Seale is having difficulty. He is in extreme discomfort ... would it be possible to have those bandages loosened?" The Great Conspiracy Trial, supra n.1 at p.264.

${ }_{150}$ The Conspiracy Trial, p.163.

${ }^{151}$ Seale's recollection of the event is corroborated by the transcript. Both clearly indicate that he was in pain during the ordeal, and that the marshals purposefully increased his level of suffering. The aforementioned website which recommends binding as a part of S\&M pleasures has this to say: "Bondage can be made both firm and comfortable and for some this may be enough without additional discomfort or pain -- which is why 'Bondage and Discipline' (B\&D) is sometimes distinguished from SM. However, bondage can also be used as a technique for inflicting pain, by forcing the body into positions that put painful stresses on particular muscles. Some bondage enthusiasts also claim aesthetic satisfaction from the bondage itself, at how elaborate or elegant it is. If this is your thrill, it's a game that may be played without any role-taking or domination at all." The website further advises that "Elaborate bondage chairs are available at a price from perve suppliers, but much can be done with the simple domestic variety. Choose a sturdy wooden chair with plenty of struts to use as fixing points." Finally, the website explicitly addresses the issue of safety: "Fortunately, none of the dangers in basic bondage are inherent; all are preventable with good techniques and sensible precautions. In general: Never make any restraint too tight, especially around joints (wrists, elbows, knees, ankles) or the neck -- anywhere that major arteries or veins are near the surface. Generally, the harder and less flexible the restraint, the looser it should be. ...you should be able to work one or two fingers between the restraint and the body." The deep undercurrents of sexual themes, underlying the sado-masochistic phenomenon takes us to another manifestation of the Seale scene. On that day, Seale gag ended with an elaborate knot on his head which looked to some like rabbit ears (quote Epstein, reminiscent of Playboys Bunnies?), but which could also remind one of a girl's ribbon tie. Was this an attempt to effeminize Seale?

152 TR. at pp.4815-17.

153 On October $30^{\text {th }}$, after the marshals tried to subdue Seale in open court by tightening his shackles and gag, and after a scuffle ensued where Seale's chair fell into the press section, defendant Rennie Davis addressed the jury: "Ladies and gentlemen of the jury, I am trying to say he was being tortured while you were out of this room by these marshals. They came and tortured him while you are out of the room. It is terrible what is happening. It is terrible what is happening." TR. at p.4845. For this outburst Davis was convicted of contempt of court and sentenced to two months in jail. This conviction was reversed on retrial. Judge Gignoux held that first, "no judicial proceedings could fairly be said to be in progress" and secondly that the cause of the breakdown of the proceedings was "the appalling spectacle.... and the marshals' efforts to subdue him." In the Matter of David T. Dellinger, 370 F.Supp. 1304, 1311 (1973).

${ }^{154}$ In the Seale contempt transcript, Judge Hoffman censored the word motherfucker into " $m$----f-----", and then attached a footnote saying: "Judge Aldrich euphemistically referred to this expression as a "vulgar term for an incestuous son" in Keefe v. Geanakos, 418 F.2d 359, 361 ( $1^{\text {st }}$ Cir.1969)", United States v. Seale, supra n.000 at p.386. There is no question that Judge Hoffman was shocked and puzzled by this language. To Seale's lawyer during Seale's contempt hearing he said: "I have known literally thousands of what we used to call Negro people," ... and who are now referred to as black people, and I have never heard that kind of language emanate from the lips 
of any of them." The mention of the replacement of Negro with black as an identifying term also supports the impression of the Judge's rigidity. It is interesting that, even in reference to this colloquialism, Judge Hoffman was careful to keep himself within the judicial discourse, relying on the observation of another judge. This pedantic insistence on propriety should be contrasted with Judge Hoffman's own forays into vulgar behavior in deciding to display the bound and gagged Seale in his courtroom. The reader should also notice that Seale (the "authentic" speaker of the verbal vulgarities) was referring to a thing, not trying to describe any violations of sexual taboos.

${ }^{155}$ From the Transcript, Verdict, Verna Sadock and Joseph Okpaku, 1970. p.41.

${ }_{157}^{156}$ One is also reminded of great opera sextets.

157 "[A] young brown woman in a brown vinyl dress, wearing a full natural, startlingly pretty, ... sat down in the court reporter's position behind the steno machine below the witness box." Shultz, Motion, supra n. 000 at p.68.

${ }^{158}$ In Re Seale, 461 F.2d., p.378, TR. pp.3641-2.

159 In Re Seale, 461 F.2d 386, TR. p. 4752.

160 "The Court: Mr. Marshal, I am not here to be laughed at by these defendants, particularly Mr. Rubin. Mr. Marshal: Mr. Dellinger, also, will you refrain from laughing?

Mr. Dellinger: That is a lie. And it wasn't Mr. Rubin. We laugh enough and you can catch us when we do but you just happened to get the wrong one.

Mr. Kunstler: Your Honor, I don't think the record should constantly have these references to chuckles. The Court: I think the record should show that and I see that the record does. I don't share your view. Mr. Kunstler: The Court has made a sally before and the room laughed and you didn't put that on the record.

The Court: I will not sit here - and you must know it by now, certainly - and have defendants laugh at my rulings, sir. And I will not hear you on that.

Mr. Kunstler: You don't mind if they laugh at me or if they laugh at someone else.

The Court: I will ask you to sit down."

In the Matter of David Dellinger, 461 F.2d at p.411.

161 TR. at pp.4815-6 (In re Dellinger, p.430).

162 Shultz, Motion, p.79.

163 Id.

${ }^{164}$ Epstein, p.269.

165 Antonin Artaud called this theater in its pure form, supra n.000, $\mathrm{p}$

${ }^{166}$ In re David T. Dellinger, p.425.

${ }^{167}$ Rights in Conflict, Convention Week in Chicago, August 25-29, 1968, A report submitted by Daniel Walker, E.P.Dutton: New York, 1968, at p.5.

${ }^{168}$ At their contempt trial before Judge Gingnoux, In the matter of David T. Dellinger, 370 F. Supp. 1304 (1973),

Abbie Hoffman testified:

"A: Well, what is missing is that we entered the Court with judicial robes. We had six-pointed Jewish stars pinned to the robes, and when I took the judicial robe off, I was wearing a Chicago policeman's shirt underneath. I think it interesting to note perhaps why the star and the Chicago policeman's shirt are missing. Perhaps that's the kind of reality that's too different for the Court to deal with at that time... Q: Now, what did you intend by the wearing of the robes and the star and the policeman's shirt to court on that day?

A: Well, I had mentioned before about guerilla theater, and I think this was an example of guerilla theater. There were no words spoken. We were saying that, in a symbolic sense, we were being persecuted, we were drawing attention to the fact that the Judge and Mr. Rubin and myself were of Jewish origins. We were trying to call attention to the fact that six million Jews had been exterminated in Nazi Germany, all with the blessing and assistance of the court, all in effect legally sent away to the gas chambers... THE WITNESS: Then with the taking off of judicial robe and the revealing of the Chicago policeman's shirt, we were attempting to say that the kind of civility and decorum and proper manners represented by the Court were only there to conceal the brutality that we met when we came to Chicago to demonstrate against the war and establish the Festival of Life.

Q: Had you up to that point made any observation with respect to other symbols or guerilla theater in the courtroom? 
A: Well, yes, I think in a sense this was not so much a court as a symbolic war taking place and there were symbols all over, from the contrast in the way the prosecutors dressed and the dress, the hair, the whole styling, the symbols around the court, the flags, there were signs out in the halls urging people to join the army, but did not specify that they had a choice of joining the army of their choice, but only one army. The seal - the seal which at least in Judge Hoffman's room, behind the seal were the cells of the jail which [sic] they took the prisoners away. There were eight portraits of the founding fathers of the country, all of which who had beards and long hair, and we were arguing over whose symbols they were. I might mention I was just down in the courtroom and they are gone, but their faded spots on the wall remain. The microphones, the whole atmosphere of the court, including the neon ceiling. So I think that in some great sense there was a symbolic war and to say it was just an attempt to ridicule the Court may be truth, but there were other reasons as well. Sometimes with symbolic struggles it's in the mind of the beholder how the symbols are interpreted."

TR. at pp.2837-9.

The scene came on the heels of the Judge's decision to revoke David Dellinger's bail. The defendants perceived this decision to be a travesty of justice. See Shultz, Motion, supra n.000 at pp.264-5; Epstein, supra no.1 at pp.401-4.

169 David Mamet, 3 Uses of the Knife (NewYork: Columbia University Press, 1998), p.67.

${ }^{170}$ Compare this with Jean Genet, The Balcony (Le Balcon): A Play in 9 Scenes (Bernard Frechtman trans., Grove Press, 1958).

${ }^{171}$ Shoshana Felman, Forms of Judicial Blindness, Or The Evidence Of What Cannot Be Seen, Traumatic

Narratives and Legal Repetitions in the O.J. Simpson Case and In Tolstoy's The Kreutzer Sonata, 23 Critical Inquiry 328 (1997).

172 Supra text accompanying n.000-000, discussing appearance of defendants.

173 Interview with his stepson, William Green.

174 In the words of Sir Thomas Browne: "Were it not for darkness and the shadow of the earth, the noblest part of the Creation had remained unseen." Quoted in John Gage, Color and Culture, Practice and Meaning from Antiquity to Abstraction (Berkeley: University of California Press, 1993), p.156. I thank Absalom J. Lahav for directing me to this source.

175 M. Mark and C.S. Pearson, The Hero and the Outlaw, McGraw-Hill, 2001, p.93, citing Robert Graves.

176 Alan Hunt, Governance of the Consuming Passions, A History of Sumptuary Laws (New York: St. Martin's Press, 1996), p.20. I thank David Seipp for calling this book to my attention.

177 Hunt, id. at $\mathrm{p}$.__ ; and compare with Chief Justice Rehnquist's robes.

178 See Sarah Barringer Gordon, Blasphemy and the Law of Religious Liberty in Nineteenth- Century America, 52 American Quarterly, 682 (2000)

${ }^{179}$ Cite cases where courts use the term judicial robes to denote the impartiality and integrity of adjudicating the law.

180 Sigmund Freud, Totem and Taboo, Norton, 1950 ed., at p.54:

It is not to be wondered at that a need was felt for isolating such dangerous persons as chiefs and priests from the rest of the community - to build a barrier round them which would make them inaccessible. It may begin to dawn on us that this barrier, originally erected for the observance of taboo, exists to this day in the form of court ceremonial.

Abbie and Jerry were reminding the audience that underneath the robe may stand a man rather different from the role he plays in the courtroom.

${ }^{181}$ Hunt, supra $\mathrm{n} .174$ at $\mathrm{p}$.

182 In the Matter of David Dellinger et al, 461 F. 2d 389, 429 (1972).

${ }^{183}$ The missing items both prove the judge's power to censor the record through his/her own selective description, and the significance of an independent record which is not subject to the judge's way of understanding the ongoing process.

${ }^{184}$ For this offense Judge Hoffman sentenced both Abbie and Jerry to seven days in prison. In The Matter of David Dellinger, 461 F.2d 389, p.402. Sustained on retrial, but no sentence applied. In the Matter of David Dellinger, 370 F. Supp, 1304, 1314.

185 TR. at p.2838.

${ }^{186}$ Id. They then continued:

"Mr. Starkman: I will object to that on hearsay grounds. (Laughter) 
Mr. Weinglass: Your Honor, of course it is not being offered for the truth, it is being offered for the belief at the time the incident occurred.

The Court: All right, for that purpose, it will be admitted and the objection is overruled."

Abbie Hoffman then proceeded to explain the symbolic meaning of wearing a policeman's shirt:

"Then with the taking off of judicial robe and the revealing of the Chicago policeman's shirt, we were attempting to say that the kind of civility and decorum and proper manners represented by the Court were only there to conceal the brutality that we met when we came to Chicago to demonstrate against the war and to establish the Festival of Life."

TR. at p.2839.

${ }^{187}$ Feb. 5, Day before robe incident, references to the judge as Hitler. Abbie: shande fur the Goyem. The fact that Abbie thought that the Holocaust was explicitly authorized and executed through legal means may show his American frame of reference, the expectation of legality. In reality the legal basis of the deportations and executions was also misty.

${ }^{188}$ Todd Gitlin, The Sixties, Years of Hope, Days of Rage (Bantam Books, 1987), pp.24-6; also Yair Auron, Les juifs d'extreme-gauche en Mai 68: Une Generation Revolutionnaire Marquee par la Shoah (Paris: Albin Michel, 1998). Defendant David Dellinger, who was not Jewish, expressed his rage during the contempt phase of the trial by saying: "You want us to be like good Germans supporting the evils of our decade and then when we refused to be good Germans and came to Chicago... now you want us to be like good Jews, going quietly and politely to the concentration camps while you and this court suppress freedom and truth." Contempt, Transcript of the contempt citations, sentences, and responses of the Chicago Conspiracy 10, The Swallow Press: Chicago, 1970 at p.72. ${ }^{189}$ On the changing historical understanding of the Jewish interaction with the Nazis, see Peter Novick. See n.000. ${ }^{190}$ In her book, Eichmann in Jerusalem, Hannah Arendt stated that, "To a Jew this role of the Jewish leaders in the destruction of their own people is undoubtedly the darkest chapter of the whole dark story [of the Holocaust, PL]." Hannah Arendt, Eichmann in Jerusalem: A Report on the Banality of Evil, p.117 (rev. and enl'ged., Viking Press 1964). One should remember that Arendt was quite influential in the 1960s, and her views on this matter were popular among American Jewish youth.

${ }^{191}$ Defendant Jerry Rubin freely associated in his memoirs: "We kept reminding Julius that everything done to the Jews in Nazi Germany was legal. Judges in black robes committed crimes in the name of the State. Do Jews become free when they put on those black robes and become those judges? Or become prosecutors for the state? Here was Jewish Shultz doing all the work for Foran, a Catholic, and his political ambitions, and helping clear the political grudges of Mayor Daley, an anti-Semite. ...Was there a victim, an oppressed person, somewhere beneath that exterior of hanging judge and vicious prosecutor?" Jerry Rubin, We Are Everywhere, Harper \& Row, New York, 1971, at pp.73-4.

${ }^{192}$ For example, Judge Alex Kozinski of the United States Court of Appeals for the Ninth Circuit was born in communist Romania. In Bucharest of 1957, his father was put "through the wringer," his loyalty questioned, and his job threatened. The reason for this evidently formative experience for the then seven-years old Alex was the following incident: at a visit to his father's workplace, Alex challenged the title of Romania's communist party paper "Free Romania." "I don't see why they call it Free Romania," he remembered asking. "There are so many people in prison." The lesson he came away with was that, "I know what it's like to always be on your guard, everything you say or do will be judged or reported." This anecdote was told in the context of Judge Kozinski's campaign for free speech on the internet. New York Times, August 18, 2001, p.8, "To One Judge, Cybermonitors Bring Uneasy Memories."

193 The Complete Greek Tragedies, vol.I, Aeschylus, David Grene and Richmond Lattimore, eds., 1959, p.320.

${ }^{194}$ Dorsen, Disorder in the Courts. As the trial of the Chicago Seven was about to end, the trial of the Panther 21 in New York City was on its way, bringing to a peak the bold and brutal challenge to court decorum.

${ }^{195}$ One may date the beginning of the involvement earlier, when the federal courts in Chicago rejected motions to grant the protesters permits to demonstrate during convention week and when Judge Campbell convened a grand jury to consider indicting the defendants. Rights in Conflict, supra n.000 at pp.59-75, and Epstein, supra n.1 at pp.35-9.

196 For the judicial robe incident, Abbie and Rubin were sentenced to seven days in prison each. In the Matter of David Dellinger, 461 F.2d 389, 402 ( $7^{\text {th }}$ Cir. 1972), rev'd. For each disturbance he caused in court Seale was sentenced to three months in prison. U.S. v. Seale, 461 F.2d 345, 388 ( $7^{\text {th }}$ Cir. 1972), rev'd. Altogether, Seale received a four-year sentence. Altogether, Abbie received eight months imprisonment, and Rubin received two years, one month, and twenty-three days. In the Matter of Dellinger, 461 F.2d at p.402. The other defendants and 
their lawyers received the following sentences: David T. Dellinger, two years, two months, nine days; Rennard C. Davis, two years, one month, nineteen days; Thomas E. Hayden, 1 year, two months, fourteen days; Lee Weiner, two months, eighteen days; John R. Froines, six months, fifteen days; William M. Kuntzler, four years, thirteen days; Leonard E. Weinglass, one year, eight months, five days. Id. at pp.401-2.

197 This was the occasion for the Seventh Circuit to develop a strict and narrow four-prong test for criminal contempt: "Four elements are required in order to support a contempt conviction under [18 U.S.C.A. §401(1)]. First, the conduct at issue must constitute 'misbehavior'... The statute secondly requires the misbehavior to rise to the level of an 'obstruct[ion of] the administration of justice.'... Third, it is evident from a reading of the statute that the conduct in question must be in the court's presence or so proximate that it obstructs the administration of justice. Since the conduct in issue here took place in the court's presence, this requirement needs no further elaboration. Fourth, virtually every decision under this Section has required some form of intent to obstruct. It is this requirement together with that of obstruction which concerns us her." U.S. v. Seale, 461 F.2d at pp.366-7. The Court also held that a judge might not break down the specifications of contempt and thereby circumvent the rule that any conviction subject to a prison sentence beyond six months entitles a defendant to a jury trial. Id.

198 The Court also reversed the contempt convictions and ordered that the new trial be held before a "a new judge [could] be chosen by the executive committee of the court below, pursuant to its local rules, but it would have to exclude judges who have officially expressed an opinion on this case." 461 F.2d 389, 396. Evidently, the Court of Appeals was concerned about the guarantee of impartiality in the next phase. Warren Burger, then Chief Justice of the United States Supreme Court, designated Judge Edward T. Gignoux of Maine to preside over the new trial. The new trial took place in 1973. Judge Gignoux's manner was restrained, regal, firm, and yet compassionate towards the defendants. They reciprocated by somberly observing decorum as well as by showering Judge Gignoux with compliments for his fairness and evenhandedness.

199 In the Matter of David Dellinger, 370 F.Supp. 1304, 1321.

${ }^{200}$ In the Matter of David Dellinger, 502 F.2d 813 (1974).

201 The Supreme Court denied the petition for Cert. from In re Dellinger. Dellinger v. U.S., 410 U.S. 970 (1973).

${ }^{202}$ Supra n.000-000 for citation and quotes from Hoffman re legality and appropriateness of measure.

${ }^{203}$ On April 2, 1969, twenty-one members of the Black Panther Party were indicted by a New York County Grand Jury for conspiring to bomb police stations, department stores, railroads, and the Bronx Botanical Gardens, and to murder various policemen." Norman Dorsen and Leon Friedman, Disorder in the Court, 1973, p.64 [hereafter Dorsen]. Bail was fixed for $\$ 100,000$ and later reduced to $\$ 50,000$, but none of the defendants could raise such sums. Meanwhile, two white radicals accused of bombing various federal buildings in New York City had bail set for $\$ 20,000$. The following was recorded in the transcript:

The Court: Do the defendants want to enter pleas?

A Defendant: You can take the indictment, you can take the entire Nixon administration and stick it up your ass. We're not willing to--

Another Defendant: This is toilet paper.

The Court: You be seated.

A Defendant: You think we got contempt for your court? You're absolutely right, Mister. It's nothing but a joke. It's a class institution that upholds your class. You going to put me in jail? I've been in jail almost a year. You're going to put me in jail, punk.

The Court: Be seated.

A Defendant: You white-haired rascist [sic] pig.

Another Defendant: This is toilet paper.

The Court: And you will be seated, too.

Another Defendant: Why don't you shut up?

${ }^{204}$ Both Justice Black and Justice Douglas' files contain letters from ordinary citizens reacting to the Chicago Conspiracy Trial.

${ }^{205}$ Dorsen, supra at p.68.

206 The trial ended on May 13, 1971, and ended with acquittals. See Peter L. Zimroth, Perversions of Justice: The Prosecution and Acquittal of the Panther 21 (New York: Viking Press, 1974).

${ }^{207}$ Even though the files of the Justices do indicate that it has not escaped their attention. In Justice Black's file one finds newspaper clippings about the trial and a cartoon portraying.... Justice Douglas' Allen v. Illinois file contains Kalven's article summarizing the Chicago Conspiracy trial in the New Republic and a cartoon..... Justice Douglas' 
opinion in Illinois v. Allen, discussing political trials, is another indication that the Supreme Court was mindful of the relationship between this opinion and the Chicago Conspiracy Trial.

208 The phrase "conduct which shocks the conduct" leaps to mind. However, it is no where mentioned in this opinion. On March 23, 1970, eight days before Allen v. Illinois was delivered, Justice Black issued a dissenting opinion in Goldberg v. Kelly, repeating his well-known opposition to "conduct that shocks the conscience as an appropriate test for violations of the due process clause." The standard, however, did live on; see e.g., Chief Justice Rhenquist's majority opinion in Salerno v. U.S., 481 U.S. 739 (1987).

${ }^{209}$ Illinois v. Allen, 397 U.S. 337, 344 (1970) decided on March 31, 1970.

${ }^{210}$ Id.

211 Id.

${ }^{212}$ Id. at pp.350-1.

213 Given the "appalling" nature of the act, is it inconceivable to expect the lower courts to say that while the Supreme Court did not hold it unconstitutional, they still (with all due humility) think it should be held unconstitutional?

${ }^{214}$ In the Matter of David T. Dellinger, 370 F.Supp., p.1311.

${ }^{215}$ Supra at n.000.

${ }^{216}$ P.350.

${ }^{217}$ U.S. v. Seale, p.363.

${ }^{218}$ U.S. v. Seale, p.359.

219 Judge Gignoux imposed no sentence on Rubin or Hoffman, although he found that "[t]he conduct charged here [to Hoffman and Rubin] was so flagrant, so outrageous, and so subversive of both respect for the court and the integrity of judicial processes as to rise to the level of an actual and material obstruction of the administration of justice." In the Matter of Dellinger, 370 F. Supp. 1304, 1315-1323 (N.D. Ill. 1973). His decision was affirmed by the Seventh Circuit Court of Appeals. In the Matter of David Dellinger, 502 F.2d 813 (7th Cir. 1974).

220 The Court continued: "From the entire record, the conclusion is inescapable that the conduct charged to Hoffman and Rubin in these specifications constituted clear misbehavior in the presence of the court, that these defendants knew or should reasonably have been aware that their conduct was wrongful, and that their conduct constituted an actual and material obstruction of the administration of justice." P.1315.

${ }^{221}$ In the Matter of David T. Dellinger, 502 F.2d 813 (1974), 817.

${ }^{222}$ The lesser (second) reason was transformed into a primary one, presumably in order to maintain the perception that a tangible interference with court proceedings occurred. Note that the Court of Appeals opined that the "seriousness of the behavior" supported that conclusion, implying thereby that the conclusion of disruption was reached independently of the 'seriousness" of the behavior. Conduct and the obstruction was quite tenuous. Id. ${ }^{223}$ There were no indications that the audience reacted inappropriately to the spectacle. Both Gignoux and the Court of Appeals ignored the Supreme Courts admonition, quoted by the Seale Court, that "The fires which [the language] kindles must constitute an imminent, not merely a likely, threat to the administration of justice. The danger must not be remote or even probable; it must immediately imperil." Seale, p.370. At the same time, and without going into lengthy analysis of the Court of Appeals opinion, it appears that the court was ambivalent about the test for criminal contempt. On the one hand it announced a very rigid and specific four-prong test. On the other hand, in elaborating on the prongs, it gave enough exceptions (buts and yets, including the phrase "unnecessary and not insignificant") in order to allow conviction even when the conduct was not actually disruptive and when a causal relationship between the behavior and disruption was not tight, In re Dellinger, supra n.000 at p.

${ }^{224}$ Judge Gignoux emphasized that the Court should be careful not to engage in vindictivement "No purpose, other than the impermissible purpose of vindicteness, would be served by sentencing... to prison" 370 F.Supp. 1304, 1322. It is also interesting to note that in the same paragraph Judge Gignoux mentions and rejects the government's argument that prison sentences would "vindicate the judicial process." It was as if he was saying: prison sentences would not vindicate the courts but rather demonstrate their vindictiveness.

${ }^{225}$ Supra n.000.

${ }^{226}$ U.S. v. Seale, 461 F.2d 345, 352 (7th Cir. 1972), citing Mayberry v. Pennsylvania, 400 U.S. 455, 465 (1971).

227 Artaud, p.48. And elsewhere he says that the theater would be preoccupied with the inquity of our social state and return to "affects that are immediate and painful - in a word,... Danger." P.42.

${ }^{228}$ Peter Brook, The Empty Space (New York: Simon and Schuster, 1968); James M. Harding, ed., Contours of the Theatrical Avant-Garde, Preformance and Textuality (Ann Arbor: The University of Michigan Press, 2000); Gay McAuley, Space in Performance, Making Meaning in the Theater (Ann Arbor: The University of Michigan Press, 
1999); Jeffrey D. Mason and J. Ellen Gainor, eds., Performing America, Cultural Nationalism in American Theater (Ann Arbor: The University of Michigan Press, 1999).

${ }^{229}$ See Artaud, supra n.000 at p.__ ; for an elaboration on Artaud's notion of the theater of cruelty, see A. Bermel, Artaud's Theater of Cruelty, Taplinger Publishing Company (New York, 1977); and Gunter Ahrends, The Nature and Function of Cruelty in the Theater of Artaud; and Foreman and Richard Allen Cave, Cruelty in the Theater and the Theater of Cruelty: Observations on Artaud and the Modern Director, in Chapters from the History of Stage Cruelty, Gunter Ahrends and Hans-Jurgen Diller, eds. (Tubinger: Narr, 1994).

${ }^{230}$ Artaud, supra n.000 at p. _. Notice that Robert Cover mentions the Bobby Seale incident in his article on Violence and the Word. Maybe the vision of this spectacle is what made him understand the deep relationship between law and violence, long before he became an academic.

231 Judge Black wrote, "It is not pleasant to hold that respondent Allen was properly banished from the court for a part of his own trial. But our courts, palladiums of liberty as they are, cannot be treated disrespectfully with impunity ... if our courts are to remain what the Founders intended, the citadels of justice, their proceeding cannot and must not be infected with the sort of scurrilous, abusive language and conduct paraded before the Illinois trial judge in this case. Illinois v. Allen, 397 U.S. 337, 346-347 (1970).

232 Epstein, supra n.1, p.431.

${ }^{233}$ Congressional Record, vol. 116, no. 73, May 7, 1970. In his introduction Senator Dole said: "Mr. President, one of the foundations of this Nation is our judicial system. That system is now under siege. ....The Trial of the Chicago 7 saw such an attempt to disrupt our judicial system." Senator Smith also said: "We must stand united against those who defame our courageous policemen by calling them 'pigs' or 'storm troopers in blue.' We must start doing something about the storm troopers in hippie beads." Id.

${ }^{234}$ Resolution of Feb. 24, 1970. Julius J. Hoffman Papers Collection, box 28, folder 15, Chicago Historical Society.

235 In re Dellinger, 370 F.Supp., p.1322.

${ }^{236}$ Id. at pp.1322-3.

${ }^{237}$ Supra n.000.

${ }^{238}$ Furthermore, if the legal principle is that a punishment should always fit the crime, how does one explain the lack of punishment in this case? Is there a crime that nevertheless comes without punishment?

${ }^{239}$ Consider a column by eminent and liberal New York Times columnist Bob Herbert, urging the Democrats to insulate themselves from the Clintons. The column starts by observing that "the Democratic Party... made a pact with Mr. Clinton that was the equivalent of a pact with the devil." Mr. Herbert then proceeds to assert that the Clintons are "a terminally unethical and vulgar couple." Both of these statements may be true. Mr. Herbert ends his column by saying that "the Democrats have no choice but to turn their backs on [the Clintons]. It's not easy to extricate oneself from the embrace of the devil, but the Democrats need to try." Thus, in one column, Mr. Clinton (equivalent of the Devil) was turned into "the Clintons", and both were then turned into the devil himself. At that moment, the danger of a witch hunt, and thus of a persecution guided by irrationality, becomes real. Bob Herbert, Cut Him Loose, New York Times, Op-ed, Feb. 26, 2001, p.A19.

${ }^{240}$ In his closing argument, chief prosecutor Thomas Aquinas Foran called the defendants "evil men", and proceeded to explain that young people are attracted to evil and therefore were vulnerable to the defendants' sinister intent. All together he used the word evil five times within three paragraphs, all in conjunction with the defendants. He concluded by referring to them as, "haters and... violent anarchists... liars and obscene haters." The Conspiracy Trial, supra n.000 at pp.569-73. Moments after the end of the trial, Anita Hoffman and Nancy Kurshan (wives of defendants Hoffman and Rubin), made their own statements before the television cameras. They burned pair of black robes crying, "We will dance on your grave, Julie. Right on." Shultz, Motion, supra n. 000 at p.348. For a theoretical explanation of the demonization of certain groups in order to explain social problems, see Erich Goode and Nachman Ben-Yehuda, Moral Panics, The Social Constructions of Deviance (Blackwell, 1994).

241 Three examples among many others are the trial of John Zenger, Judge Learned Hand's opinion in the Masses case, and the Progressive case.

${ }^{242}$ Supra n.000.

${ }^{243}$ Or think of his performance in the Chicago Conspiracy Trial as an exception to the generally fine judicial career he has enjoyed.

${ }^{244}$ I am grateful to Chris Tomlins for making this point.

${ }^{245}$ Quoted supra, p. 000 accompanying note 000 